النتائج التنموية لحظر الربا

في ظل الاقتصاد الحقيتي

"دراسة فقهية اقتصادية معاصرة"

إعداد: د. علي سيد إسما عيل

مدر بسر 1لاقت:ماد 1لإسبلإمي والمعاملاتت

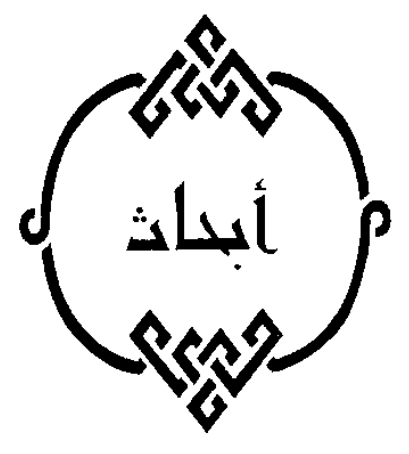

قسم الدراسات الإسلامبة - كلية الآداب

\title{
مامعة المـنبا
}

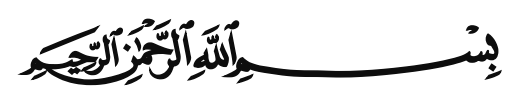

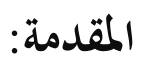

الحمد لله الذي هدانا للإيمان، وحذّرنا من المخالفة والعصيان، وأشهٌُ أن لا لا

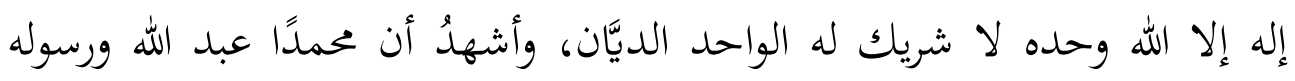
خيرة الإنس والجان. وبعد:

فقد انتهى المسلمون في عصر الرسالة عن التعامل بالربا؛ لأن الله حرمه؛ إيمانًا منهم وتصديقًا بما جاء به العليم الخبير، وكانوا يعرفون من أسباب تحريمه أنه ظلم،

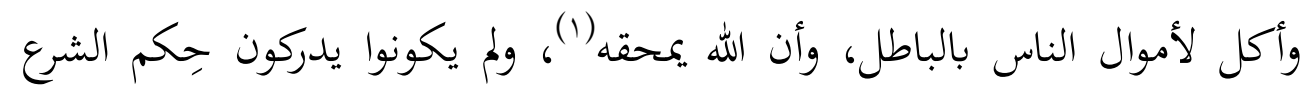

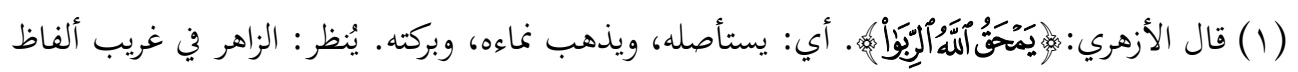

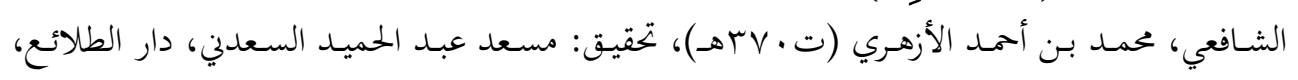

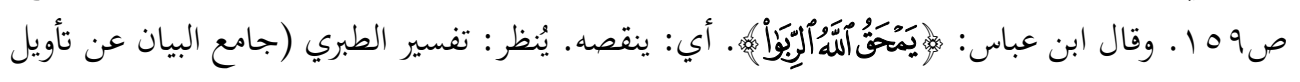


وأسراره، فضلاً عن آثاره الاجتماعية والاقتصادية على الفرد والمجتمع؛ لأن ثقافتهم وفكرهم الاقتصادي لا يؤهلهم لمعرفة مفاسد الربا، وآثاره على الاقتصاد كما هو

الحال اليوم (1)

من أجل ذلك حمل هذا البحث عنوان: (النتائج التنموية لحظر الربا في ظل الاقتصاد الحقيقي: "دراسة فقهية اقتصادية معاصرة")؛ ليوضح ما سيكون عليه الحال والمآل إذا تم حظر الربا من معاملاتنا الاقتصادية المختلفة على مستوى الأفراد والمجتمعات، بين الشعوب وبعضها، وبين الدول وبعضها.

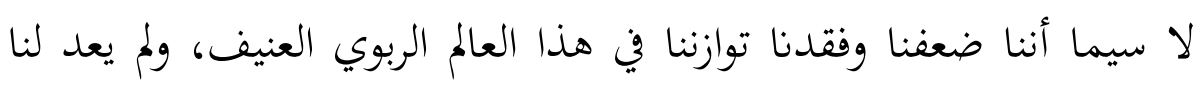
من نجاة إلا إذا تخلصنا منه، ودخلنا في نظام تعاملي غير ربوي؛ لكي ننقذ أموالنا،

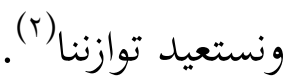
ومن ثم فالأولوية المصيرية الآن هي ضرورة حظر الربا بكل صوره وأشكاله، وإلغاء كل المعاملات القائمة عليه، واستبدال نظام اقتصادي بها، يقيم السياسات الاقتصادية على قواعد ومفاهيم مالية صحيحة، بتعل الإنسان مقيّدًا في تصرفاته

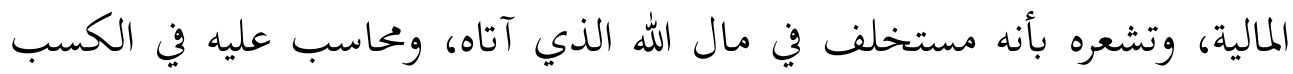

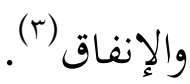

آي القرآن)، محمد بن جرير الطبري (ت . آسهـ)، تحقيق: عبد الله بن عبد المحسن التركي، دار هجر،

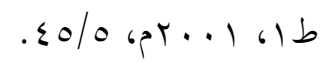

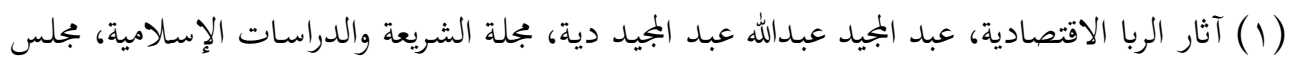

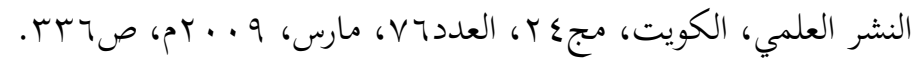

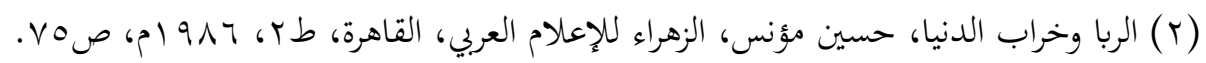

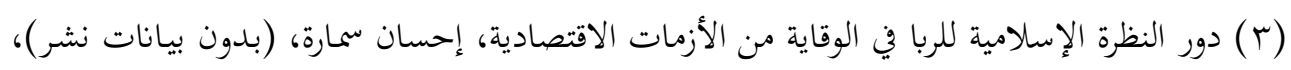


وتحريم الربا ليس لأجل التحريم، وإنما لما يترتب على التعامل بـه مـن المضار

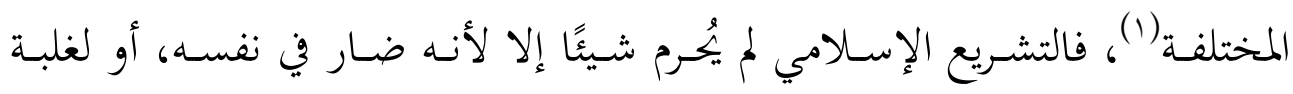

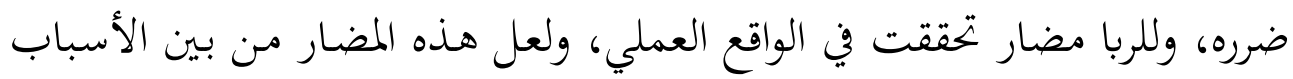
التي اقتضت حكمة العليم الخبير تحريمه من أجلهاب(r). يقول أستاذنا العلامة عبد الكريم الخطيب: "وكان طبيعيًا أن يتدخل الإسلام في هذا الضرب من المعاملات الجائرة، التي تغتال الضعفاء، وتمتص عصارة الحياة فيهم، وتقطع أواصر الرحمة، والأخوة بين الناس والناس" "(r).

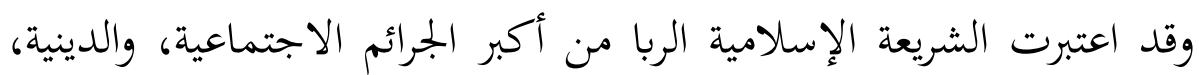

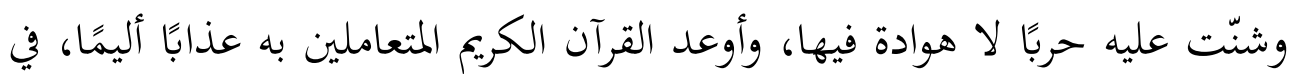
الدنيا والآخرة(ع)، كما ذكر علماء الإسلام في حكمة تحرة فيهم الربا وجوها معقولة، كشفت الدراسات الحديثة وجاهتها، وأكدتها، وزادت عليها (ه).

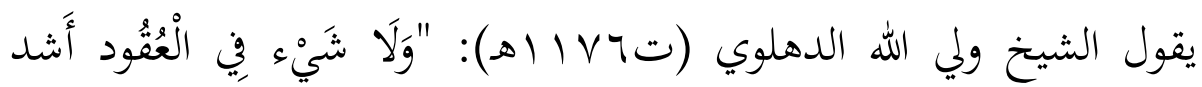

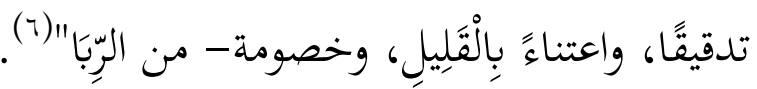

(1) الربا وآثاره الاجتماعية والسياسية والاقتصادية في مختلف الديانات المؤمنة والكافرة، فاضل عياث

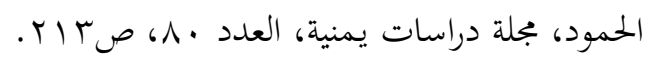

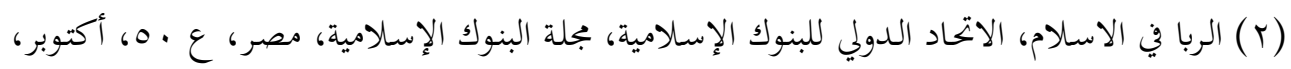
.

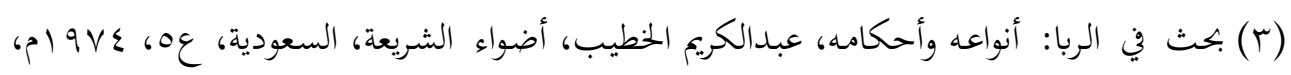
.1.. (ع) روائع البيان تفسير آيات الأحكام، محمد علي الصابوني، مكتبة الغزالي، دمشق، مؤسسة مناهل

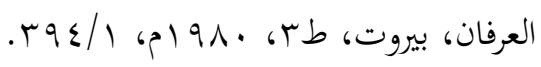

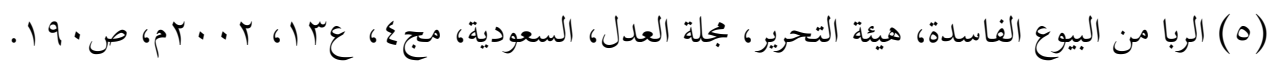

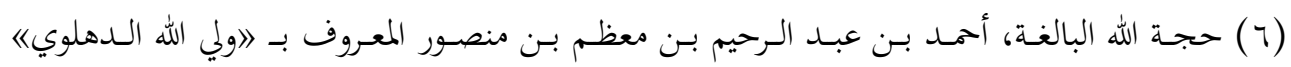

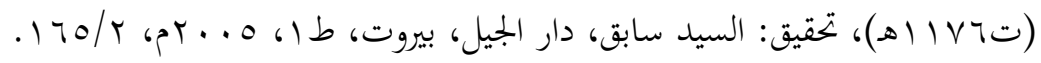


ونحن لم نسق هذا الكلام كي نثبت صدق ما جاءت به الأديان السماوية،

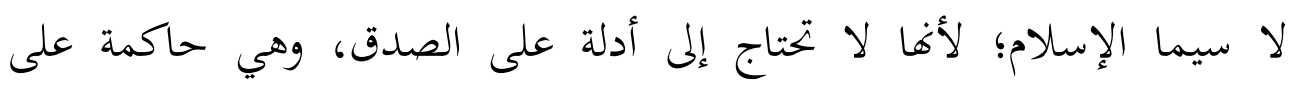

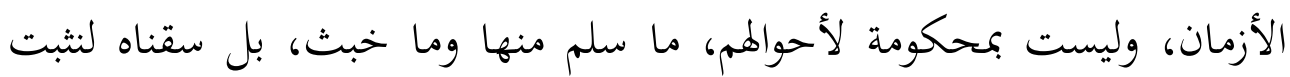

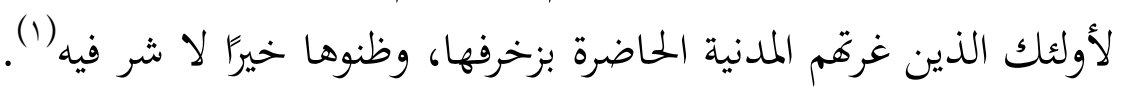
أهمية الدراسة والباعث على تناولها:

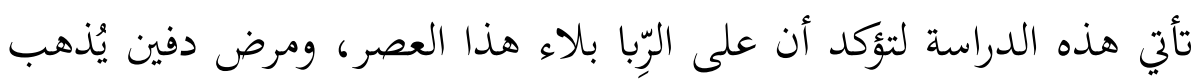

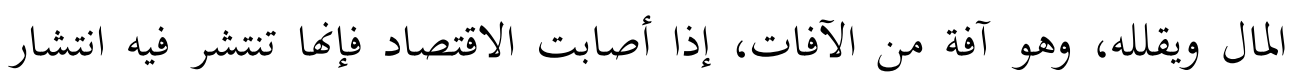

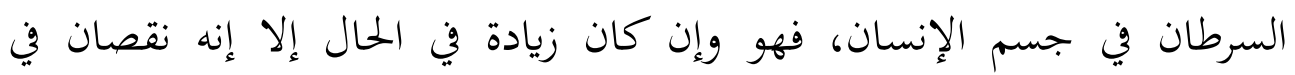
الحقيقة.

وتستمد هذه الدِرَاسَة أهميتها من تزايد الاهتمام بموضوع الربا، والإسهام في

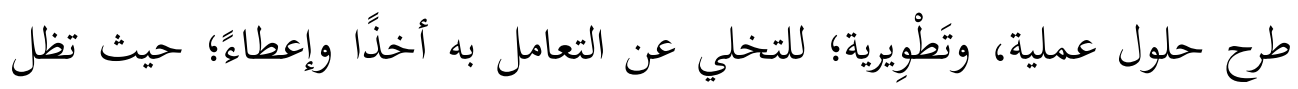

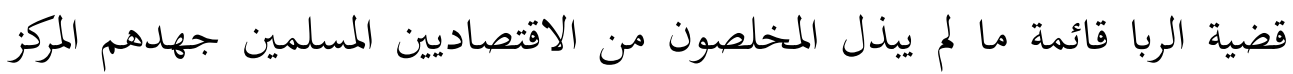

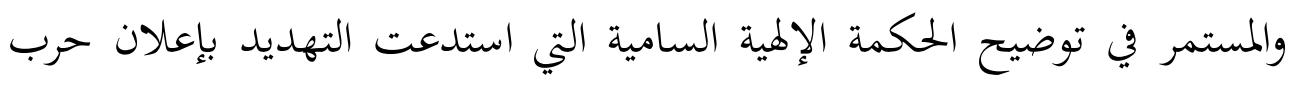

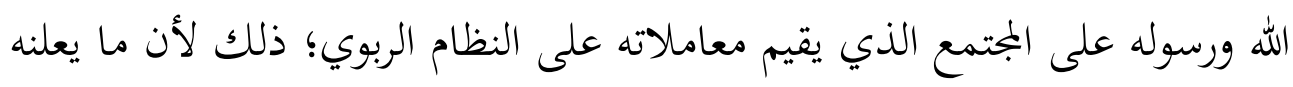

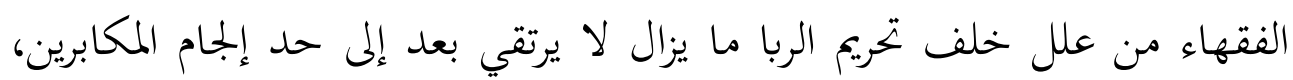

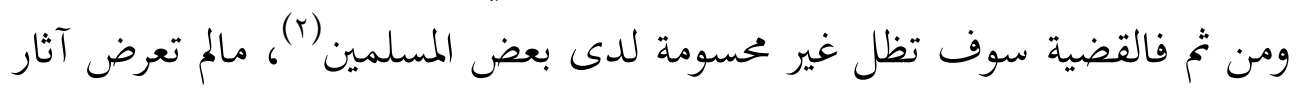

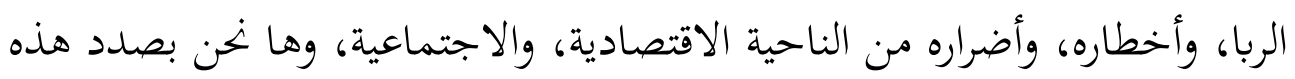

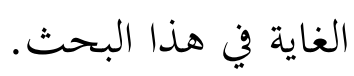
إشكالية الدراسة:

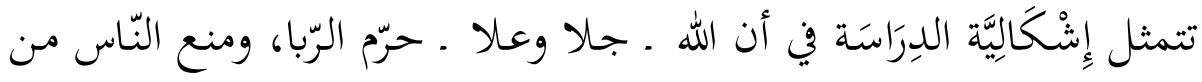

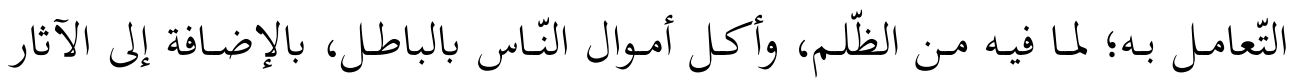

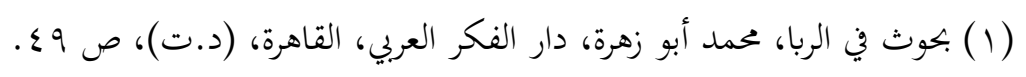

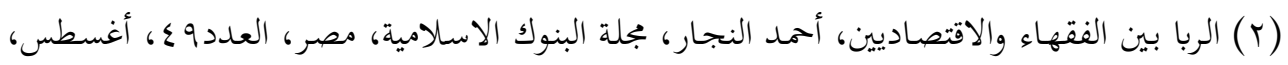

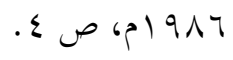


العظيمة، تبعًا لتطوّر العمليات الاقتصاديّة، ومنها: سوء توزيع الثّوة، وإهدار الموارد الاقتصادية، وضعف التّنمية الاقتصاديّة والاستثمار .

ومـنهج الإسـام هـو كفـاء، وشفاء، ووفـاء، ووقاء، والربا تخريـب للاقتصـاد

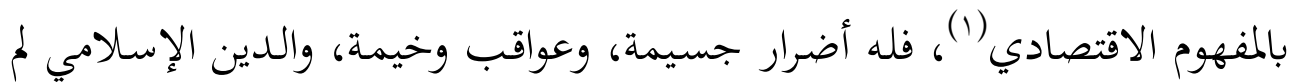
يأمر البشرية بشيء إلا وفيه سعادتا، وعزّها في الدنيا والآخرة، ولم ينهها عن شيء

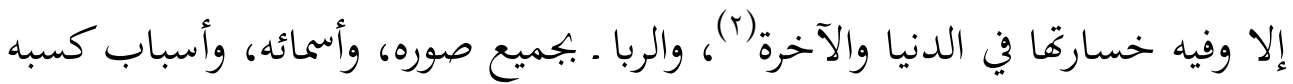
ـ مُعطل للنشاط الاقتصادي، وظالم للآخذ والمعطي معًا.

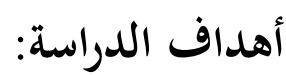
تحدف هذه الدِرَاسَة إلى تسجيل دقيق للنتائج التنموية لإلغاء الربا وحظره من معاملاتنا المعاصرة؛ حيث إنه يفضي إلى مفاسد وأضرار خطيرة، تهدد الإنسانية في جميع ججالات حياها: الأخلاقية، والاجتماعية، والاقتصادية، والسياسية؛ فالحكمة إلهائ

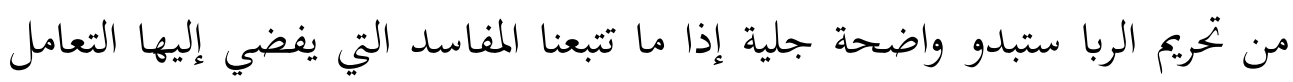
بله (r)

والمطلوب منا ومن غيرنا من جموع الباحثين، فضلاً عن المتخصصين من

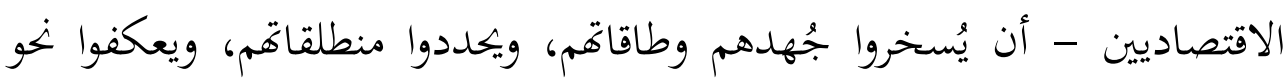

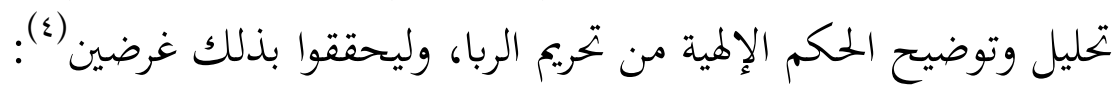

(1) تحريم التعامـل بالربا، محمـد كمـال فراج، مجلة التوحيد، القـاهرة، عج، جمادي الآخرة، بملو ام، ص \& (r) الربا: أضراره وآثاره في ضوء الكتاب والسنة، سعيد بن علي بن وهف القحطاني، تقديم: صالح

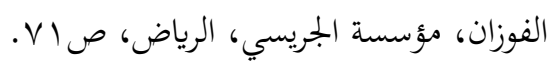

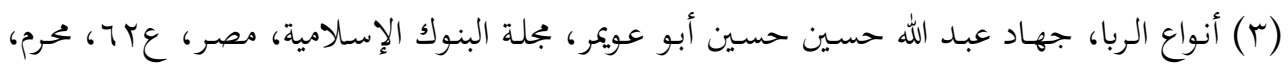


" الغرض الأول: أن يخرجوا للعالم ـ في جلاء ووضوح - روعة الحِكم التي تكون

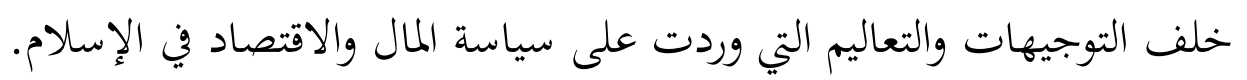

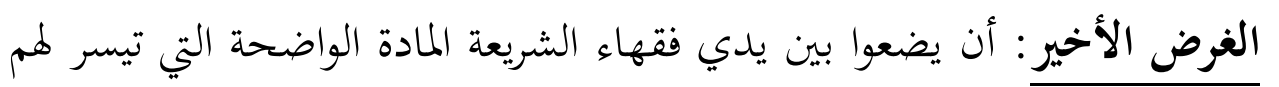

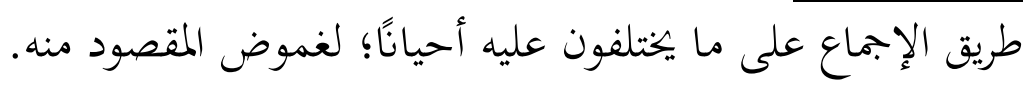

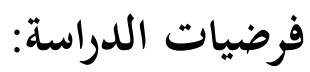

$$
\text { تنطلق هذه الدراسة من بضع فرضيات أبرزها: }
$$

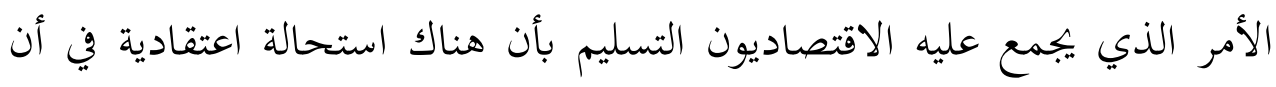

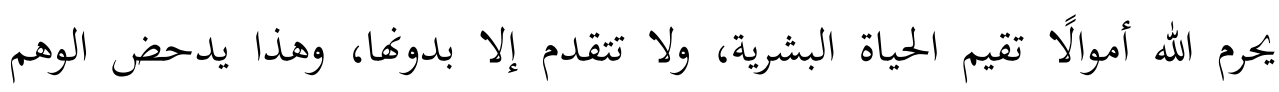

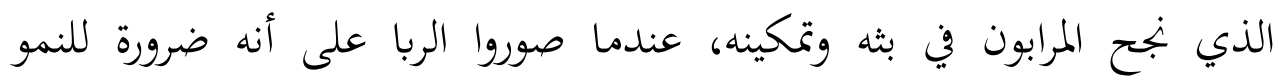
الاقتصادي والعمرائ، وأن النظام الربوي هو النظام الطبيعي.

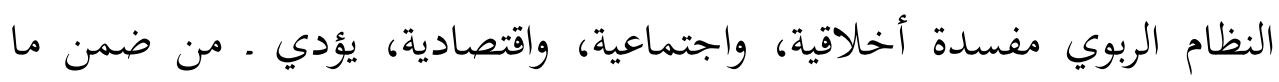

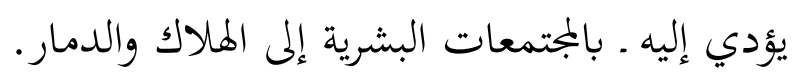

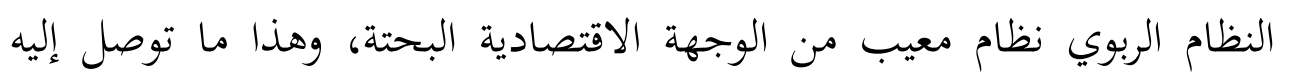

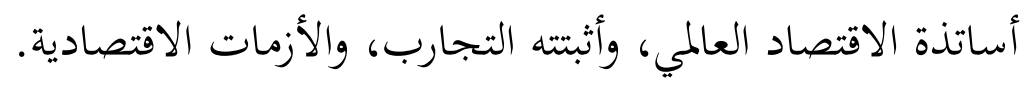

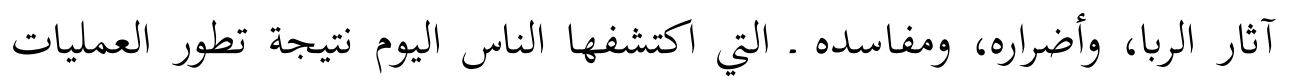

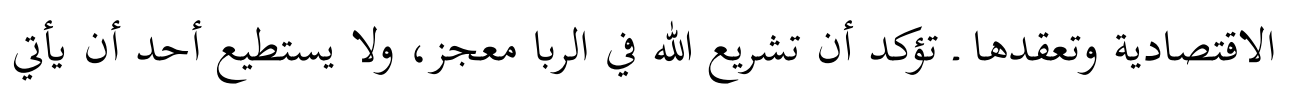
بمثله.

\section{منهجية الدراسة:}

اعتمد الباحث عَلَى المنهج الوصفي، القائم عَلَى الاستباط، والتحليل،

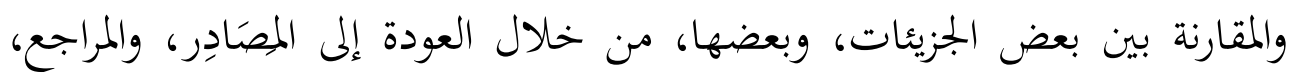

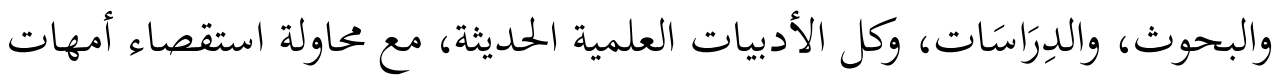

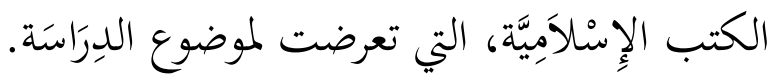




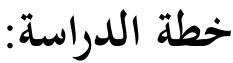

أما عن خُطة الدراسة فقد قسمتها إلى مقدمة، وتمهيد، وتمانية مباحث، وخاتمة، وفهرس المصادر والمراجع.

تناولت في المقدمة: أهمية الدراسة والباعث على تناولها، وإشكالياها، وأهدافها، وفرضياقا، ومنهجيتها، وخطتها.

أما التمهيد فقد حمل عنوان: (حول ماهية الربا: مدخل وملهان حول الإطار

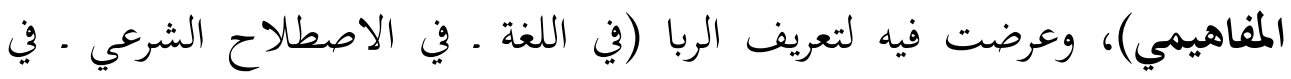

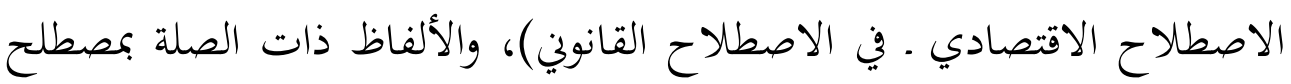

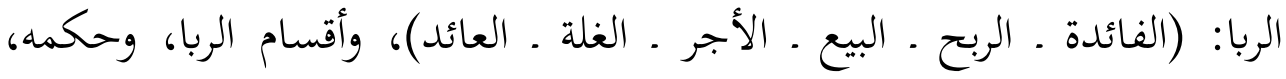
والحكمة في تحريمه، ونشأة التعامل بالربا وتطوره.

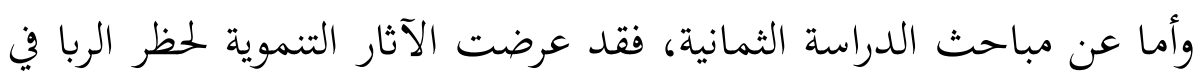

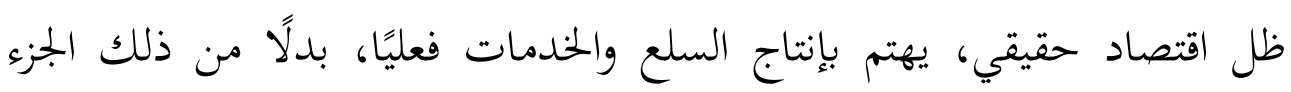

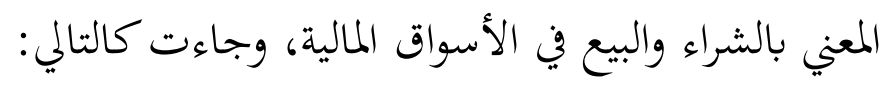

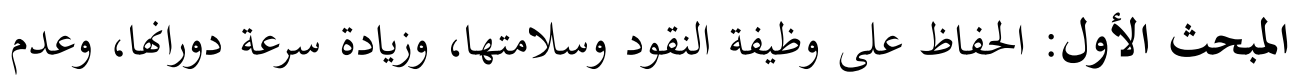

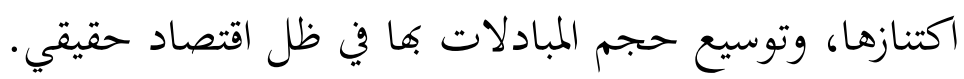

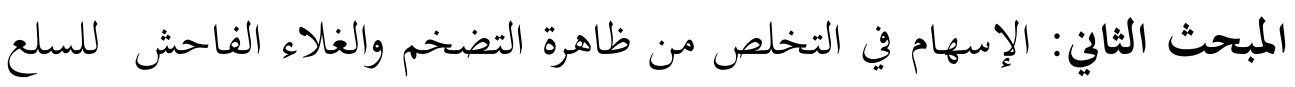
والمنتجات في ظل اقتصاد حقيقي. المبحث الثالث: توقف عملية تعطيل أموال المسلمين والتحرز من استخدامها بصورة عكسية عليهم وإضرارهم بها.

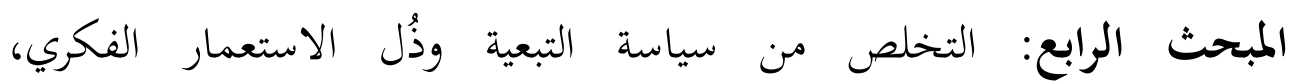
والاجتماعي، والاقتصادي، والسياسي، والعسكري.

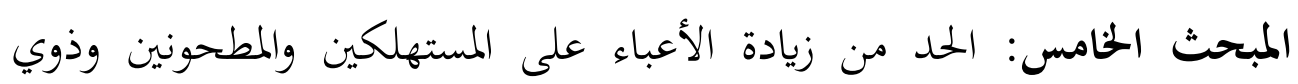
الطبقات الفقيرة. 
المبحث السادس: التخلص من الركود والكساد المحليين والعالميين. المبحث السابع: القضاء على ظاهرة الطبقية المالية والمجتمعية وسُوء توزيع الثروة؛ لبناء استقرار المجتمع الإسلامي وتقدمه. المبحث الثامن: التوجه نحو المشروعات المنتجة والاستثمارية في ظل اقتصاد الإداء حقيقي. أما الخاتمة فقد عرضت فيها لأهم النتائج والتوصيات التي توصل إليها البحث. وأخيرا فهرس المصادر والمراجع. 


\section{تمهيد}

\section{حول ماهية الربا: مدخل حول الإطار المفاهيمي}

أ ـ ماهية الربا:

ا ـ تعريف الربا في اللغة: الربا في اللغة هو الزيادة على الشيء، قال ابن

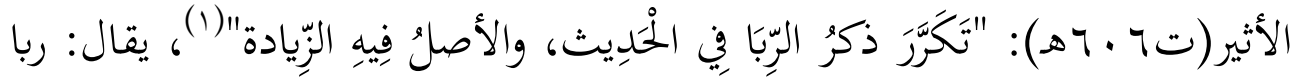

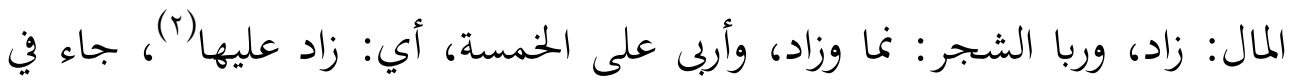

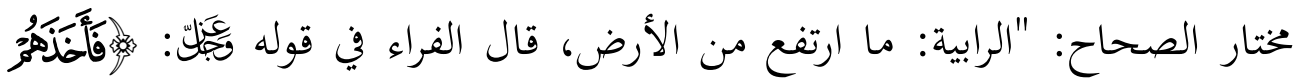

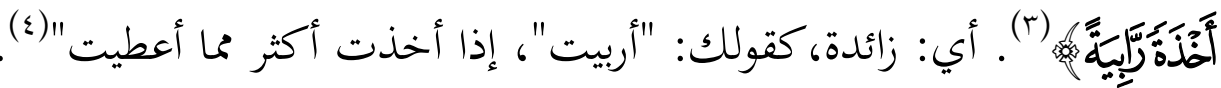

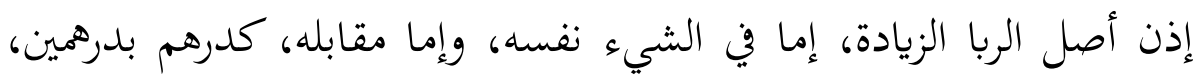
وهو في الشرع: الزيادة على أصل المال من غير عقد تبايع (o) ويطلق الربا على كل

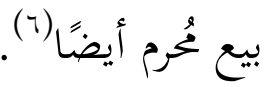

(1) النهاية في غريب الحديث والأثر، محمد بن عبد الكريم بن الأثير (ت7 ــهـ)،تحقيق: طاهر أحمد

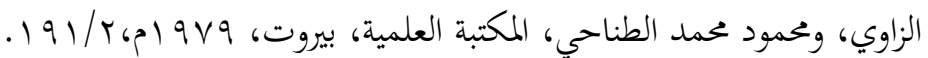

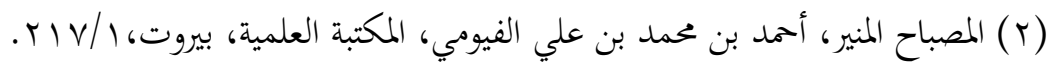

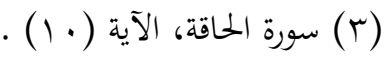

(ع) مختارالصحاح، أبو بكر الرازي، تحقيق: محمود خاطر، مكتبة لبنان ناشرون، بيروت، 0 إـ اهـ، ص ص (0) لسان العرب، محمد بن مكرم بن منظور الأفريقي المصري، دار صادر، بيروت، طس، ع إـاهـ، $. r .0 / 1 \varepsilon$

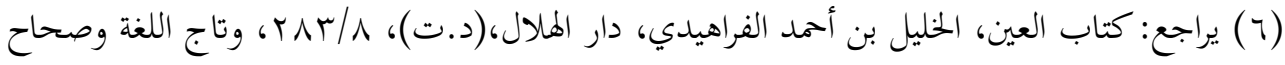

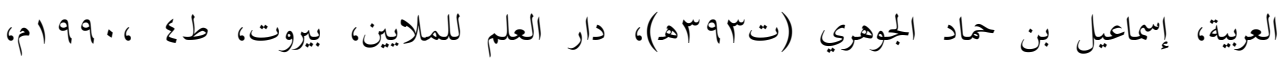

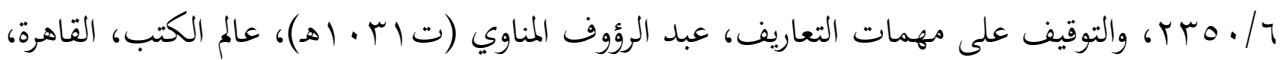


r. ال. تعريف الربا في الاصطلاح الشرعي: اختلف الفقهاء في تحديد معنى

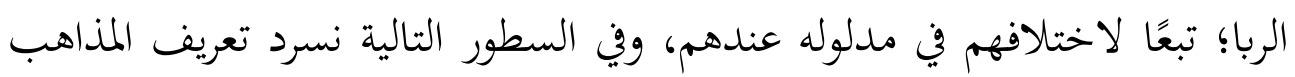

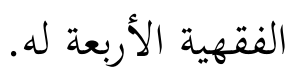

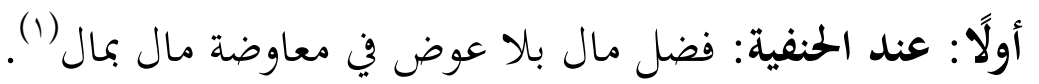

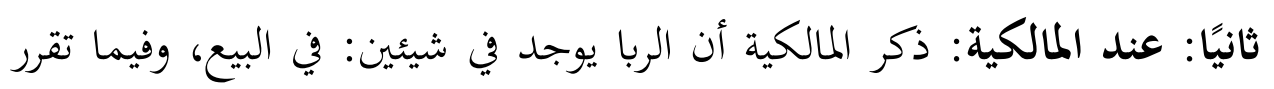

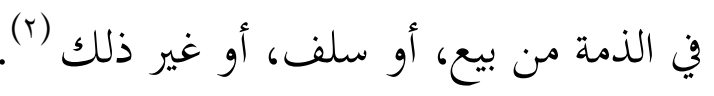

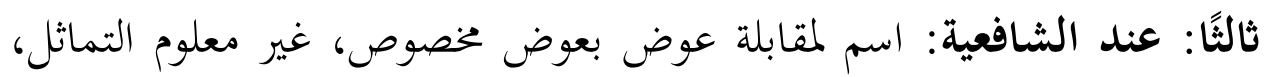

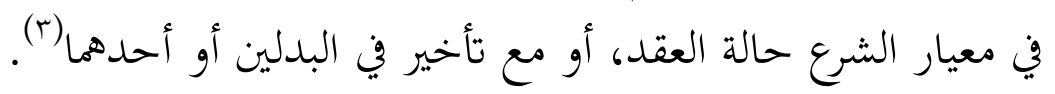

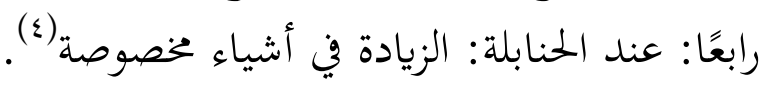
والحاصل من تعريف الربا عند المذاهب الأربعة اختلافهم في معنى الربا؛ تبعًا

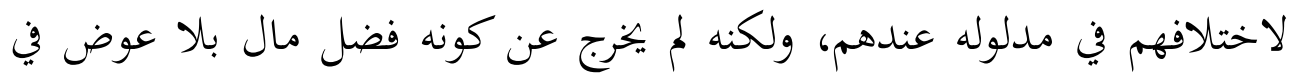

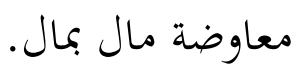
r. تعريف الربا في الاصطلاح الاقتصادي: يعرف الربا في الاقتصاد بأنه

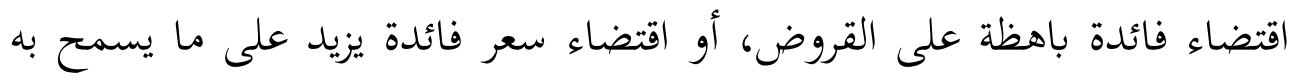
(1) تبين الحقائق شرح كنز الدقائق، فخر الدين عثمان بن علي الزيلعي، دار الكتب الإسلامية، القاهرة،

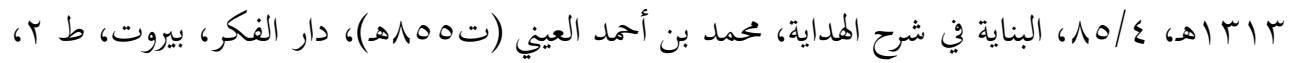

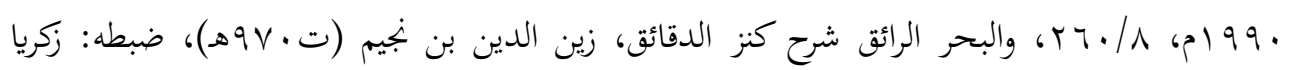

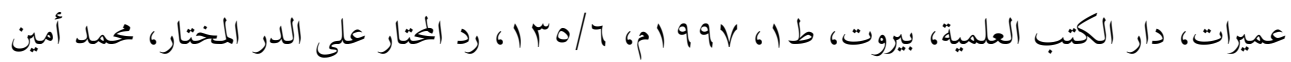

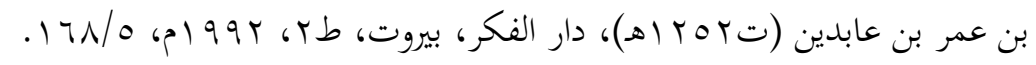

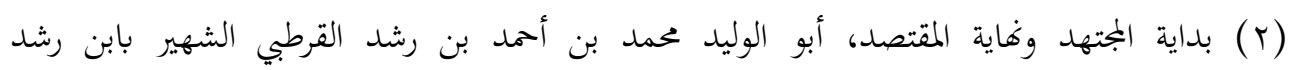

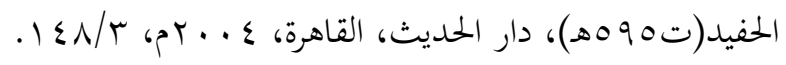

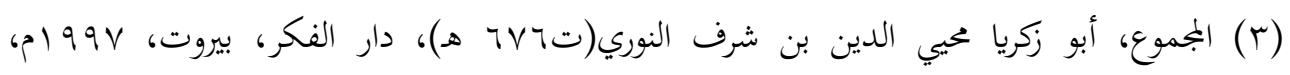
r. ro/l.

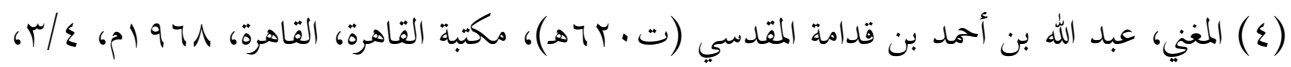

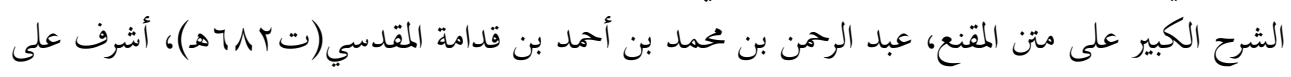

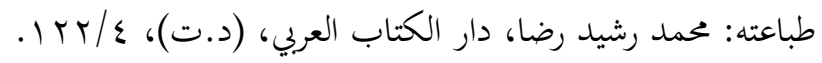


القانون(') أي: أن الربا في الاصطلاح الاقتصادي يعني: الربح غير المشروع، الذي يكسبه الدائن من المال الذي يقرضه للغير. ع. تعريف الربا في الاصطلاح القانولي: يعرف الربا في القانون على أنه

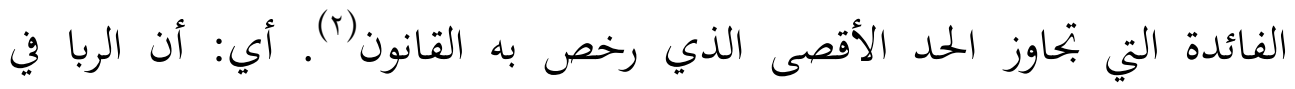
الاصطلاح القانوني يختص بربا القرض، مع اشتراط توفر الدائن على الربح الفاحش. ب ـ الألفاظ ذات الصلة بمصطلح الربا: ا ـ الفائدة: عبارة عن مبلغ يدفع مقابل استخدام رأس المال، ويعبر عنه عادة كمعدل أو نسبة مئوية (سعر الفائدة)(r)، والفائدة ظاهرة اقتصادية في الأدبيات

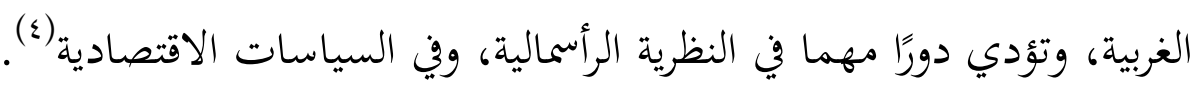

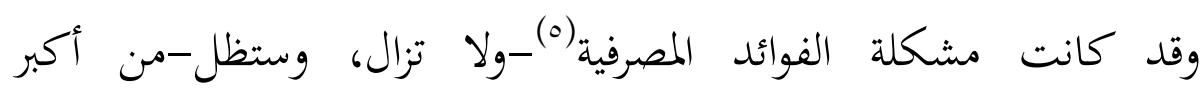

المشكالات في عالم التجارة، والمال، والاقتصاد، إن لم تكن أكبرها على الإطالاق (؟).

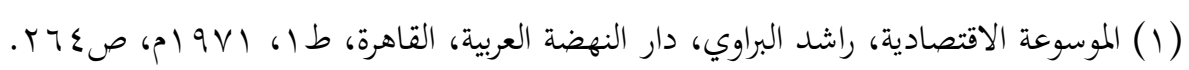

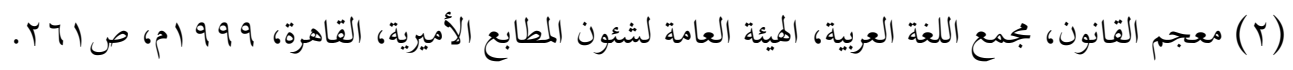

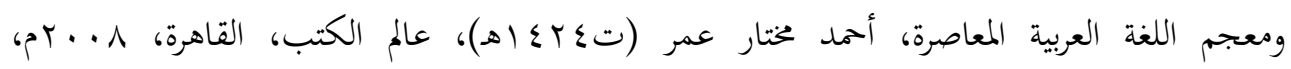

$$
\begin{aligned}
& .1 \mathrm{~V} 0 \mathrm{~N} / \mathrm{r}
\end{aligned}
$$

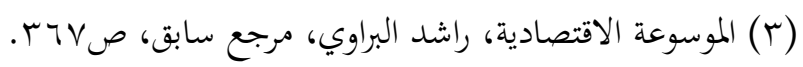

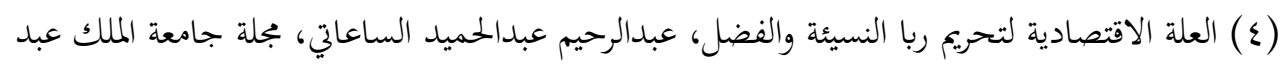

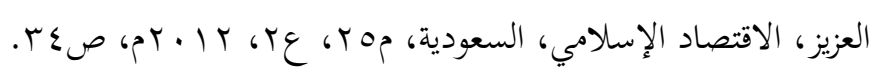

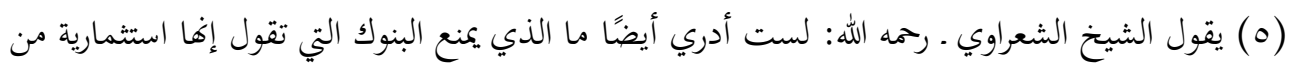

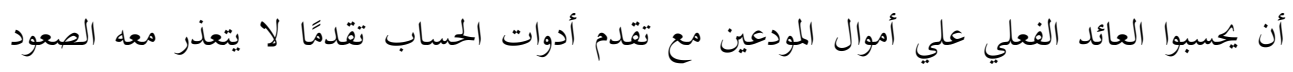

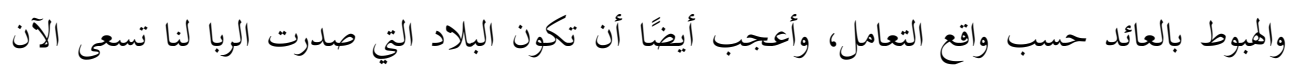

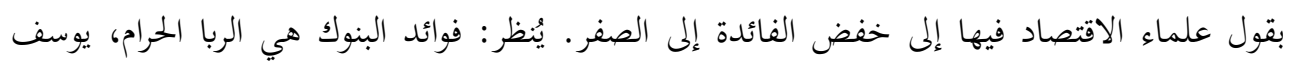

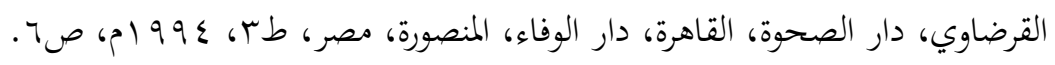

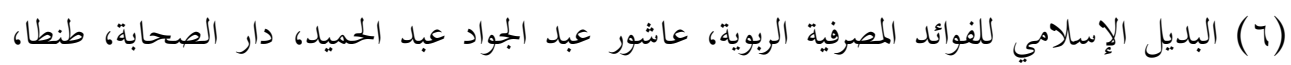

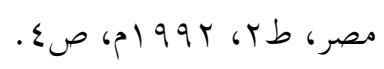


والفائدة على رأس المال تكلفة الانتظار، وليست تكلفة التقليب والمخاطرة(1) وهي استغلال لجهد الناس، وهي جزاء من غير بذل جهد، ولأن

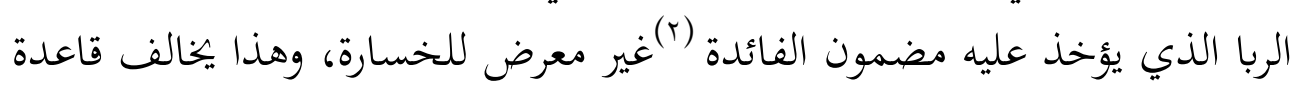

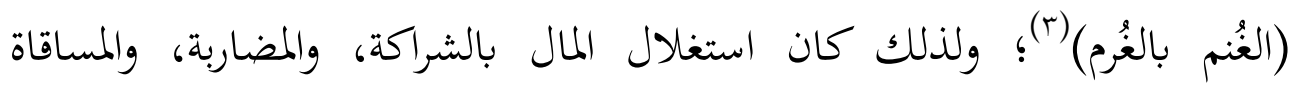
بشرطها جائز، لأنه تنتفع به الجماعة، ولا يستغل جهد الآخرين، بل يكون وسيلة

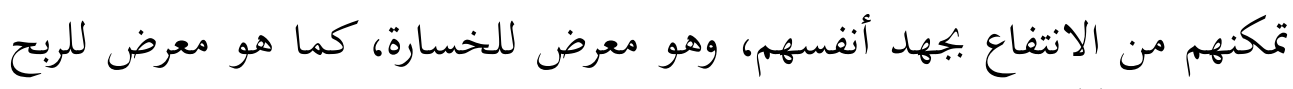

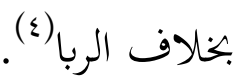

وهي ـ أي الفائدة ـمرادفة للأثرة والأنانية، فالدائن يعتبر نفسه مستحقًا

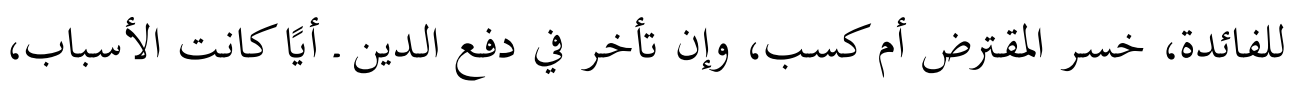
فهو يتعرض لفوائد تأخير، تزيد في العادة عن المعدلات الأصلية(ه). أما عن العلاقة بين الربا والفائدة فمع أن الفائدة لفظة حديثة نسبيًا، ولم تكن بحرى على ألسنة المتقدمين، إلا أن الرأي السائد بين المعاصرين يجعل الفائدة

(1) الاقتصاد الإسلامي بين الفكر والتطبيق، حسين شحاتة، دار النشر للجامعات، طץ، با ـ بم، ص.

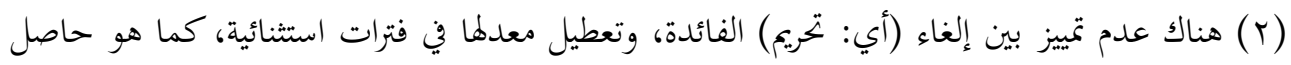

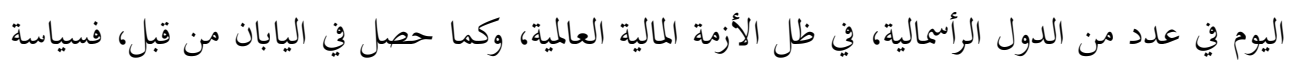

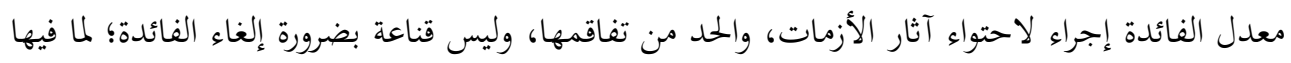

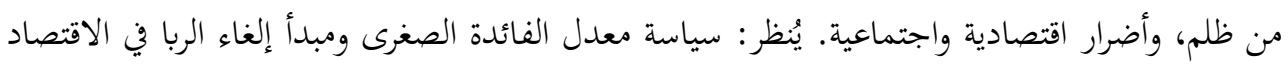

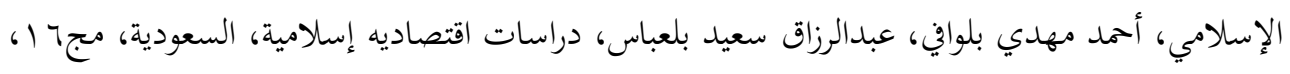

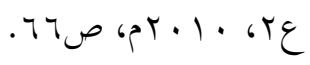

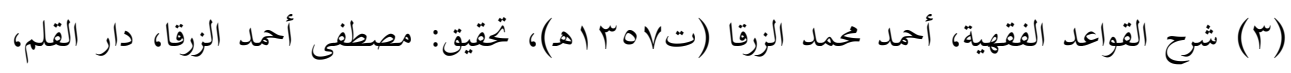

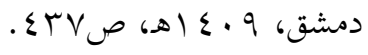

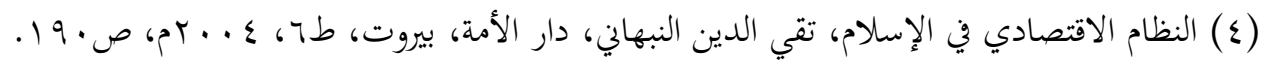

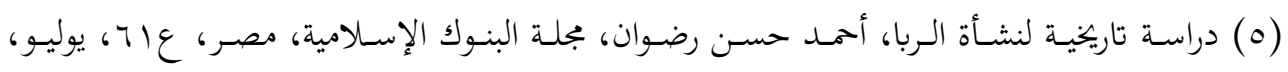
.100 (p) 1911 
والربا لفظين لمعنى واحد، ولأن الفائدة تختص بالقروض، بينما يتعلق ربا السنة بالبيع، والبيع غير القرض (1) Y. الربح: هو الذي يجصل عليه الشخص أو المشروع بعد خصم جميع المدفوعات. أي: أن الربح هو ما نتج عن عملية تبادل بتحاري، تتقلب فيه النقود

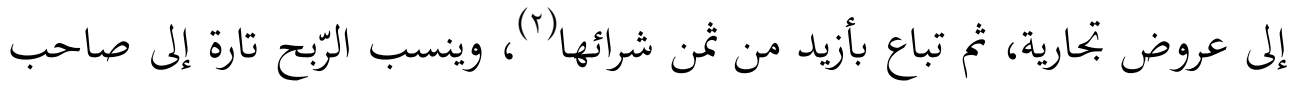
السيّلعة، وتارة إلى السّلعة نفسها (r).

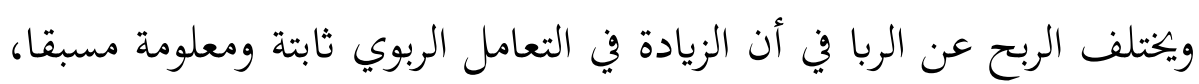
وأما الربح في التجارة فيكون غير ثابت، وغير معلوم مسبقًا، بل هناك احتمال

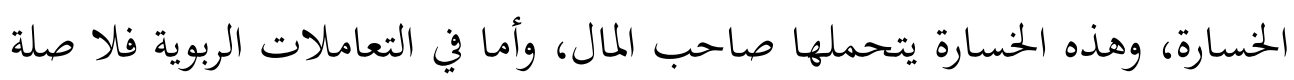
لصاحب المال بالخنسارة(ع). وقد يطلق بعضهم على الربا ربحا، وهذا قلب للموازين؛ لأن الربح المزعوم

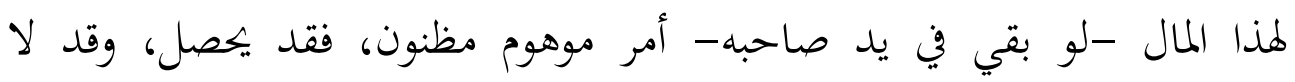

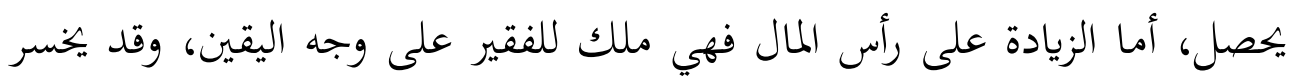
ذلك المحتاج في تعامله برأس المال الذي استدانه، فيجمع عليه خسارته في التجارة، والزيادة التي يطلبها المرابي على رأس المال (ه).

(1) ربا الجاهلية والفائدة، نوري عبد الرسول الخاقاني، مجلة مركز دراسات الكوفة، العراق، عَ،

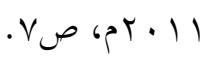

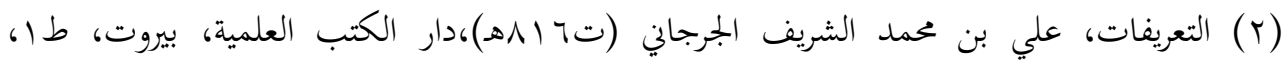
.1 . $9 / 1$ (م) 1914

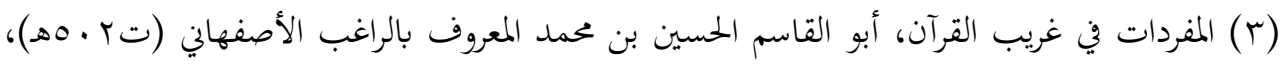

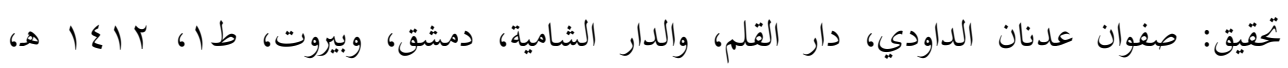

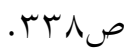

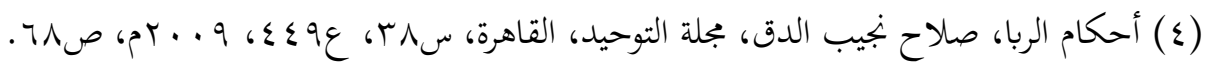

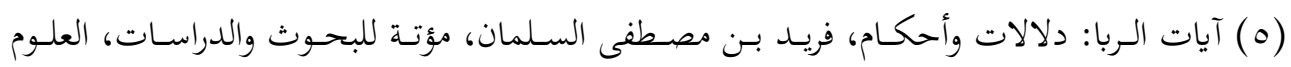

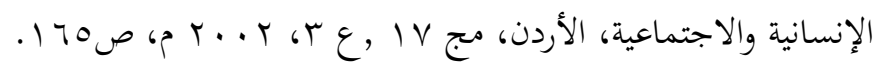




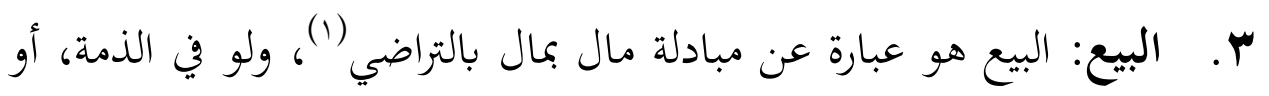

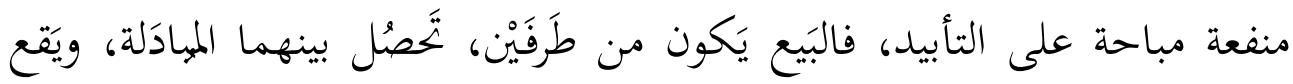

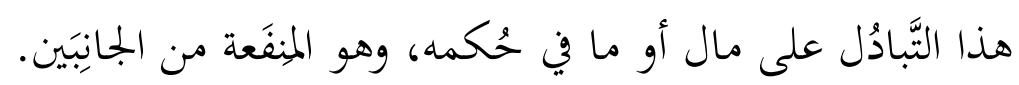

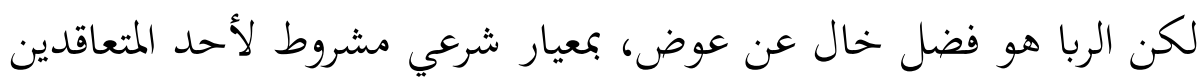

في معاوضة(r)

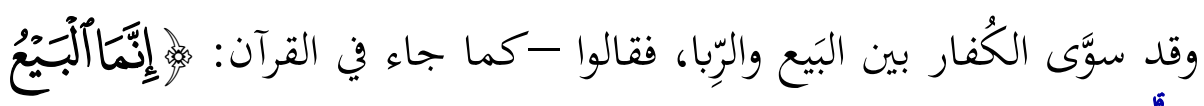

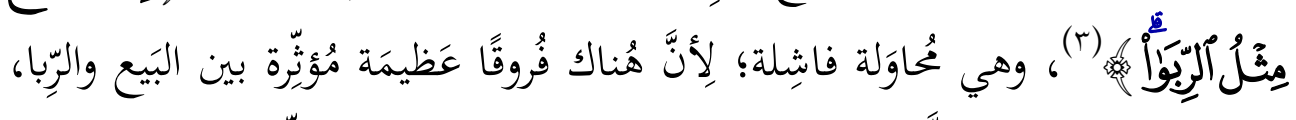

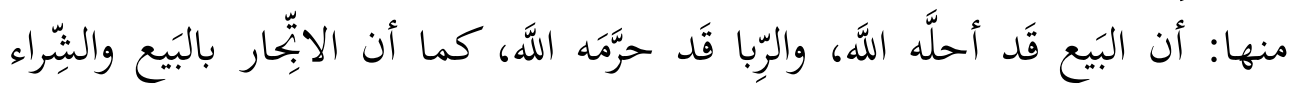

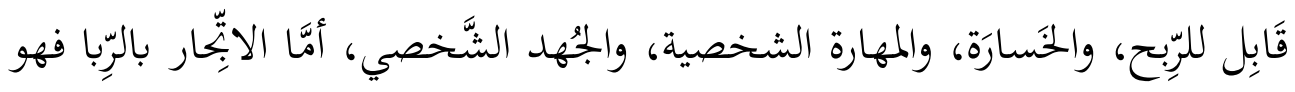

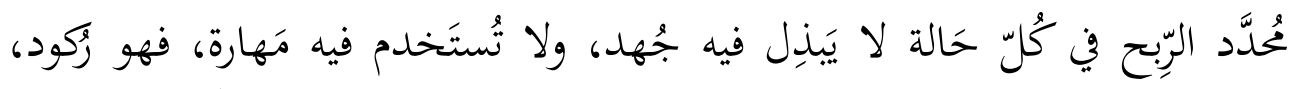

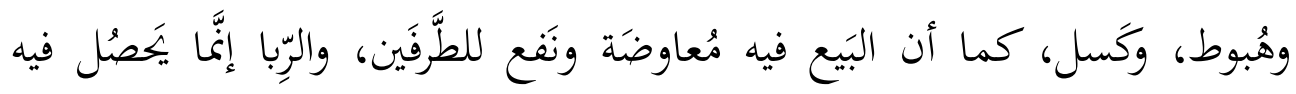

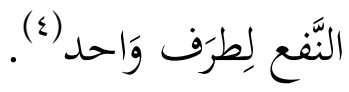

والخلاصة أن الربا خال من كل ذلك؛ لأنه عبارة عن إعطاء المال مضاعفًا

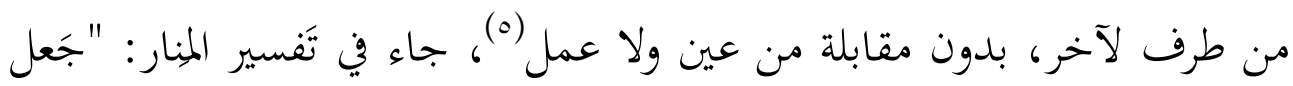

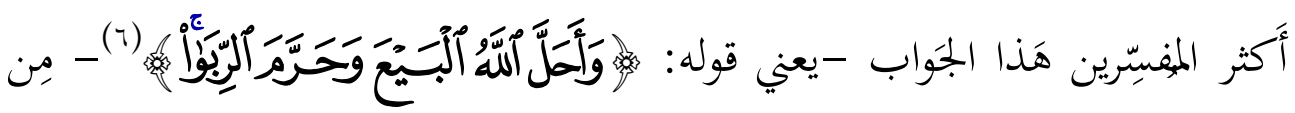

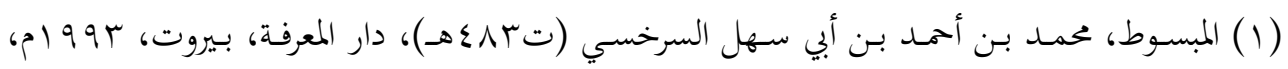

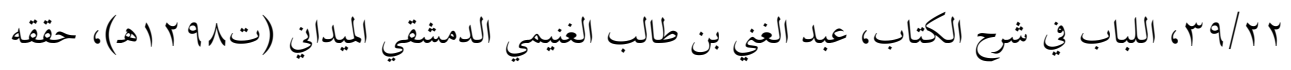

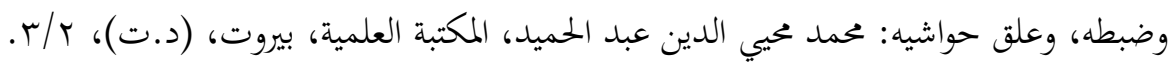

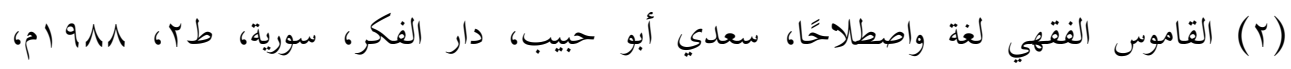

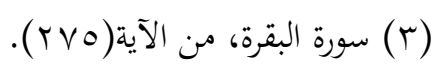

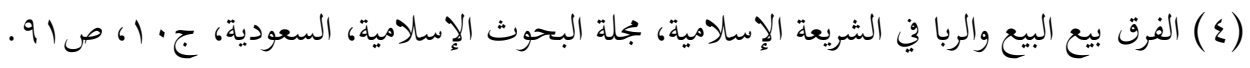

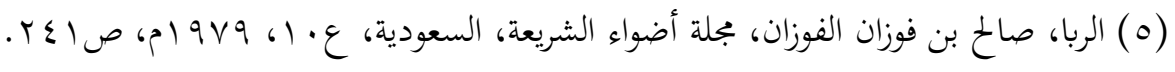

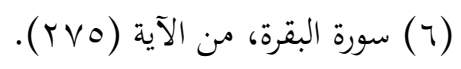




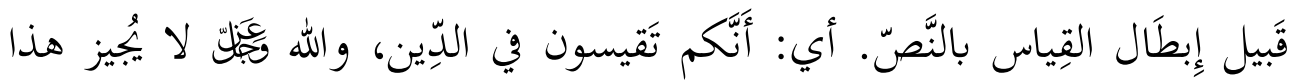

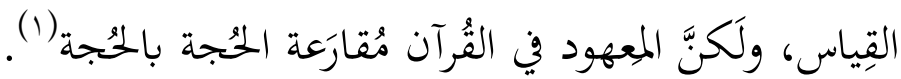
ع. الأجر: الأجر هو ثمن المنفعة في العقد المتفق عليه بين طرفين، والأجر يكون مقابل خدمة، يقوم بها شخص، فلا يستحق هذا الأجر أحد، إلا بعد قيامه بالخدمة المطلوبة منه، وأما الربا فلا عبرة فيه بوجود هذه الخندمة، وإنما هو زيادة

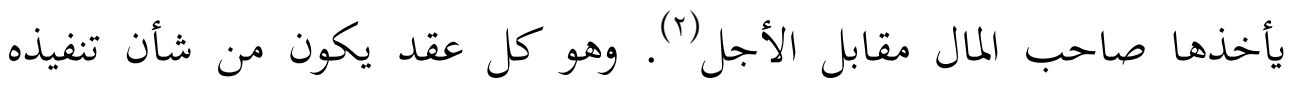

استغلال حاجة الضعيف، وزيادة الفقير حرمانًا، وزيادة الغني ثراء حتى يطغى (r). ه. الغلة: الغلة هي الدخل من كراء دار، وأجر غلام، وعائد أرض من ريعها،

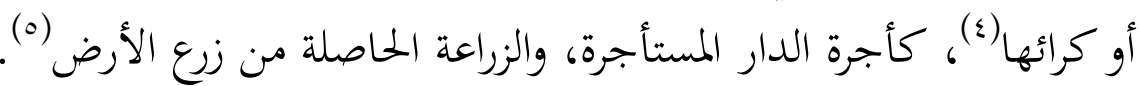
أما الربا فهو فائض القيمة الذي يأكله القوي دون مبرر(ج)، وأسوأ أنواع الربا لهرها وأبعدها عن الخُّق الإنساني هو إقراض المعوزين بفائدة ربوية؛ لأنه استغلال لحاجاتمم، وعمل على استمرار عجزهم وعوزهم، والواجب الإنساني يقضي بمساعدقم، إما قرضًا حسنًا بغير ربا، أو صدقة لوجه الله غير مستردة (v).

(1) تفسير القرآن الحكيم (تفسير المنار)، محمد رشيد رضا (ت عـهبا (هـ)، الهيئة المصرية العامة للكتاب،

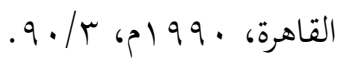
(r) التدابير الواقية من الربا في الإسلام، فضل إلهي بهامة بن شيخ ظهور إلهي، رسالة دكتوراه(غير منشورة)،

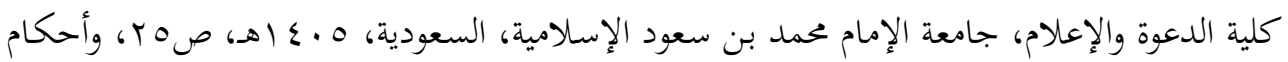

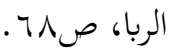

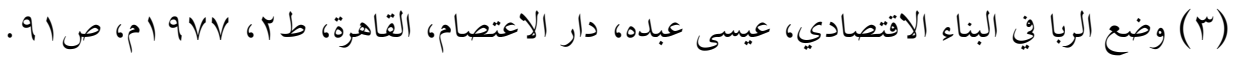

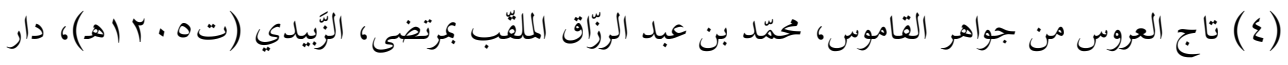

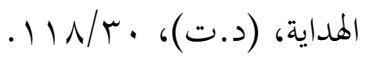

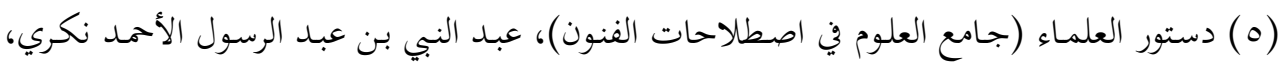

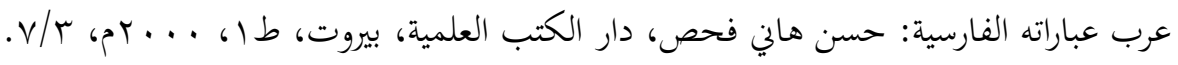

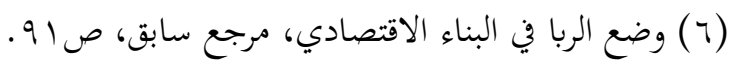

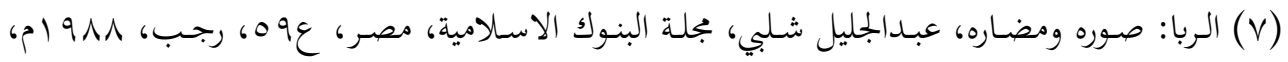


7. العائد: العائد هو الربح المكتسب من إجمالي المال المستثمر، أو الكمية

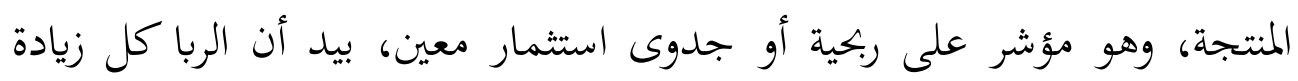
مشروطة في العقد، خالية عن عوض مشروع (1).

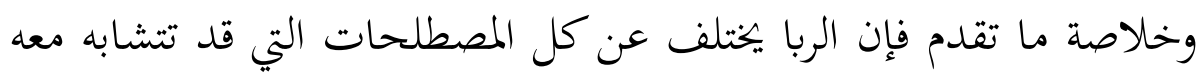

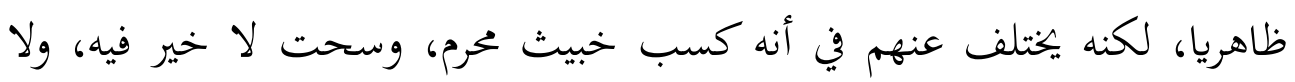

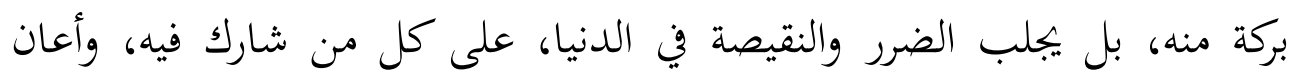

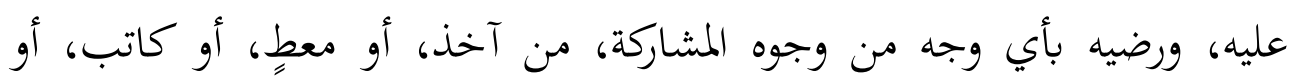

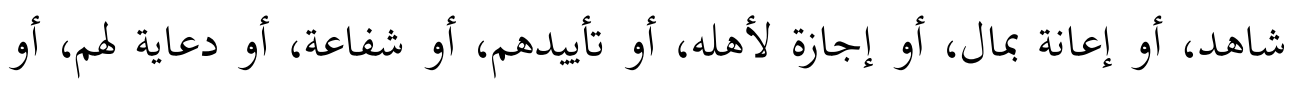

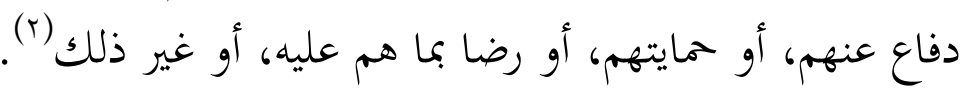
ج · أقسام الربا: قسم جمهور الفقهاء الربا إلى قسمين: ربا الفضل، وربا النساء، والفضل في

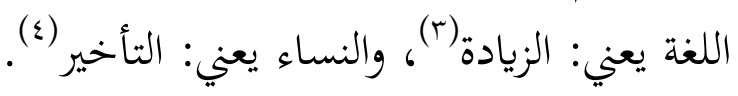

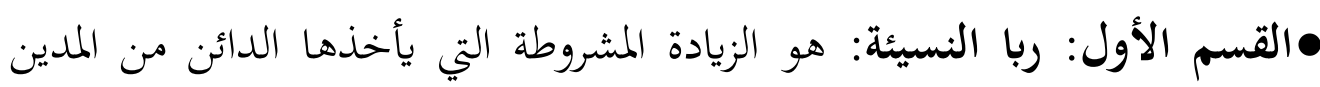

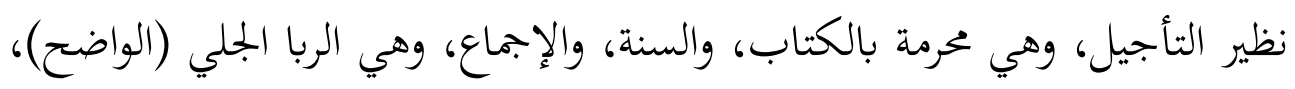

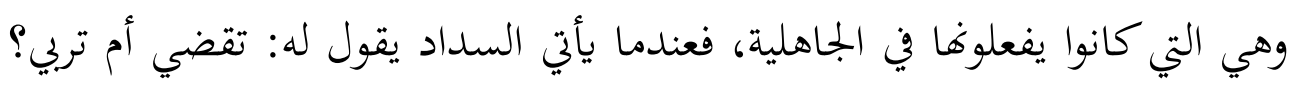
وكلما أخره زاد في المال المقترض، حتى تصير المائة آلافًا(ه).

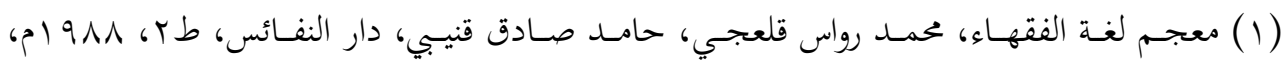
ص人וז.

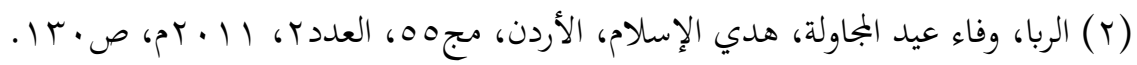

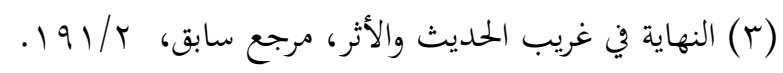

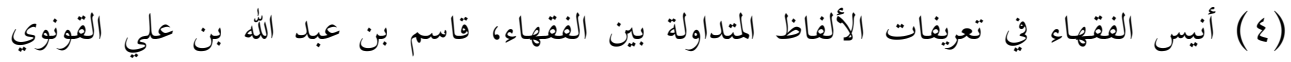

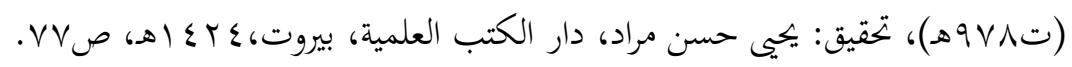

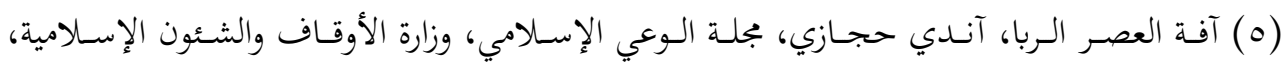

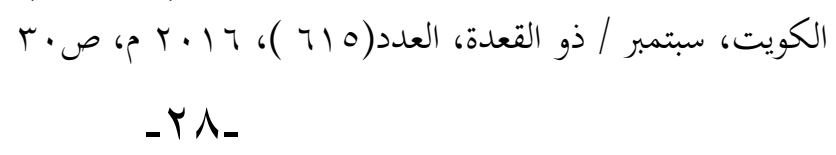


ه القسم الثاني: ربا الفضل، هو زيادة عين مال، شُرطت في عقد بيع على المعيار الشرعي، وهو الوزن أو الكيل، عند اتحاد الجنس، وهو بيع النقد بالنقد، والطعام

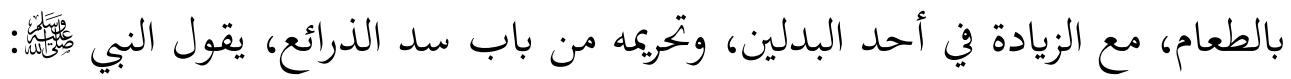

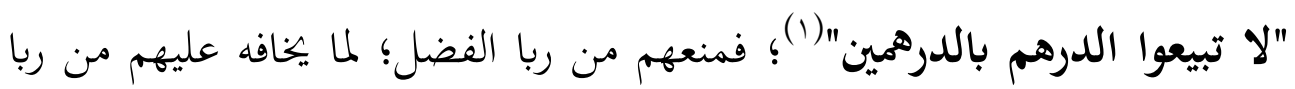

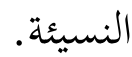

$$
\text { دـ ـ حُكم الربا: }
$$

حرم الإسلام الربا، وشدد على تحريمه، بنصوص بينة قاطعة في القرآن والسنة،

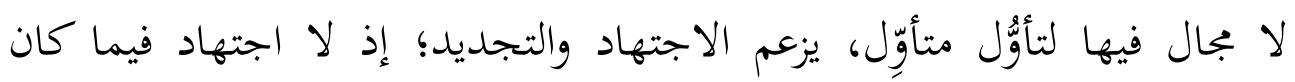

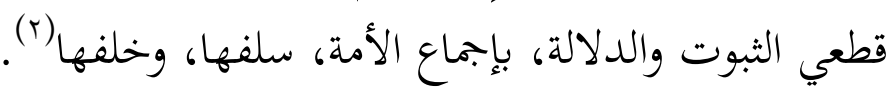
وقد أشار الفقه الإسلامي إلى محاذير الربا في المجتمعات، فهو يخلق الكسل بين المرابين؛ لأفم يربكون من كد سواهم من الناس، كذلك فهو يطوح بالمشاعر إس

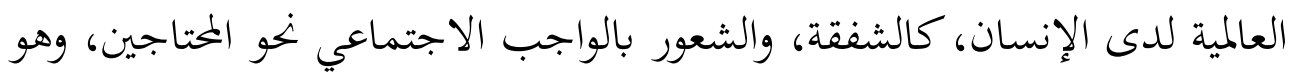
ينطوي على الخداع والعبودية، ولا يحقق المساواة والتجانس بين أبناء الأمة

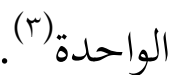

والإسـلام مـا حرم شـيًُا إلا وفيـه ضـرر على النساس عظيم، فالشـريعة كلهـا

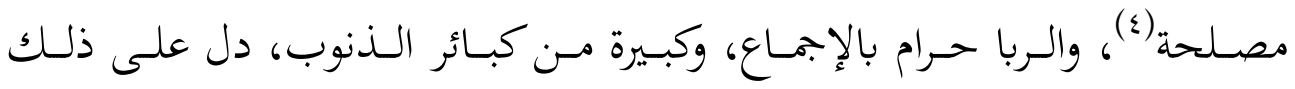
الكتاب، والسنة، والإجماع.

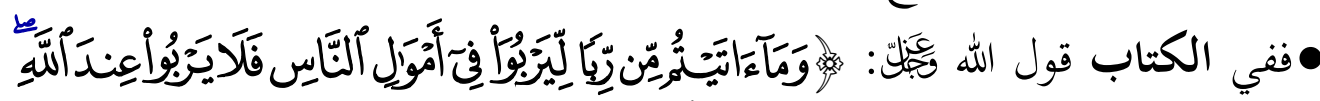

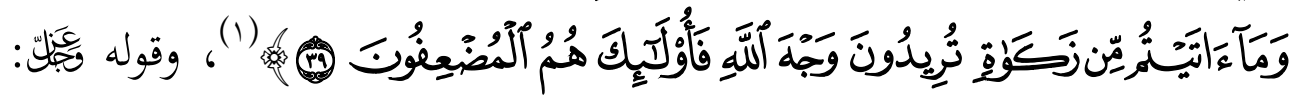

$$
\begin{aligned}
& \text { (1) صحيح مسلم، كتاب المساقاة، باب الربا، حديث به ه. r. }
\end{aligned}
$$

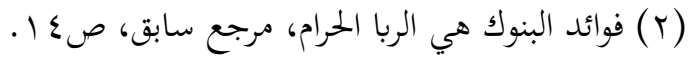

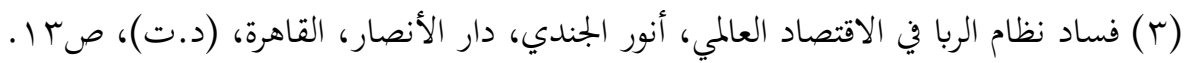

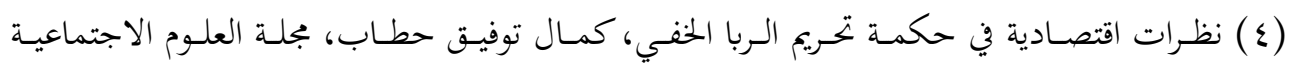

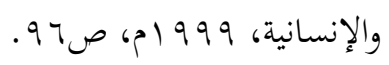




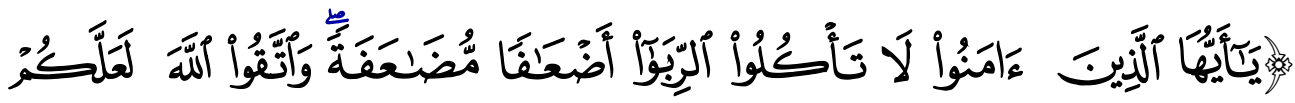

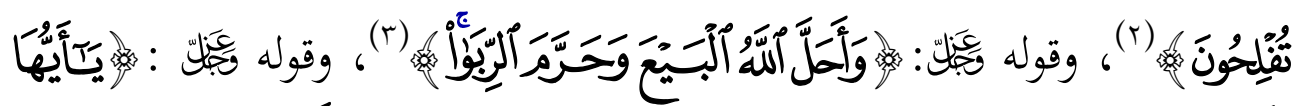

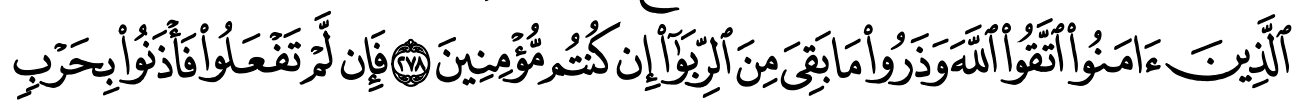

مَنَ

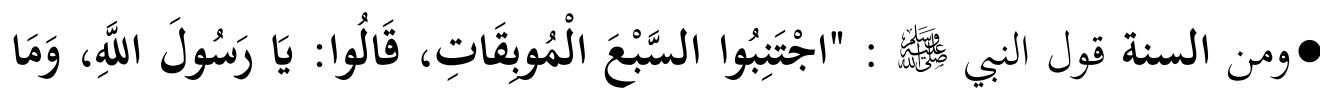

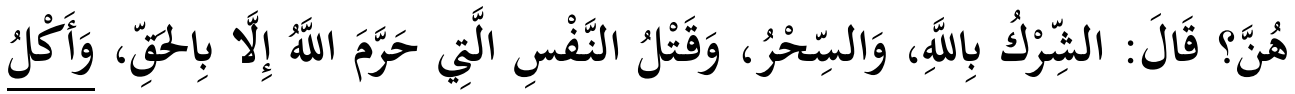

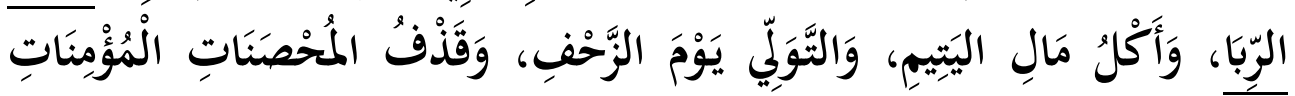

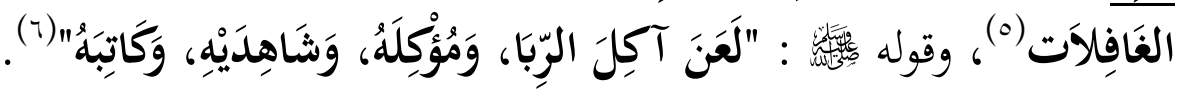

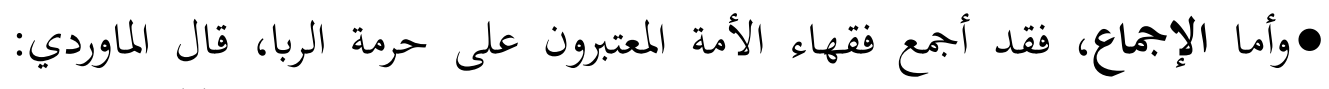

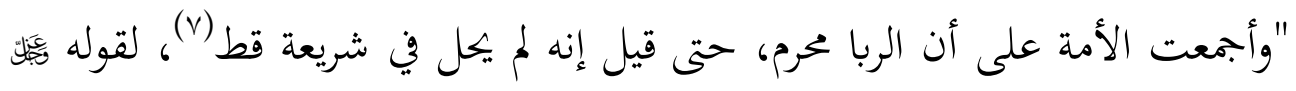

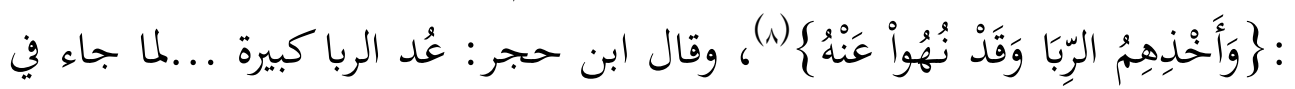

الأحاديث الصحيحة، من تسميته كبيرة، بل هو أكبر الكبائر وأعظمها (9).

$$
\begin{aligned}
& \text { (1) سورة الروم، الآية (qه). }
\end{aligned}
$$

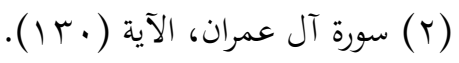

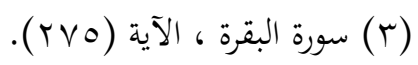

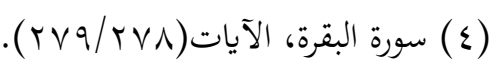

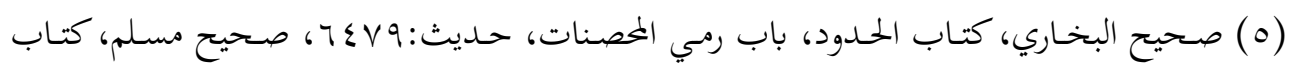

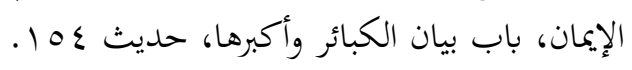

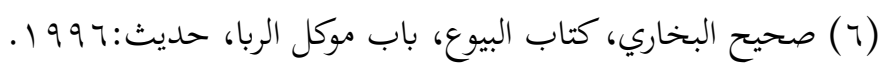

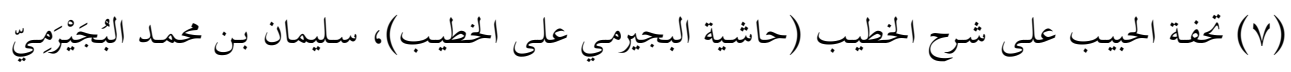

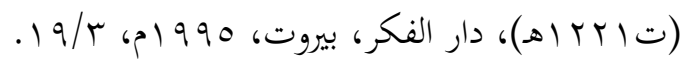

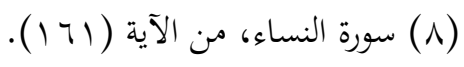

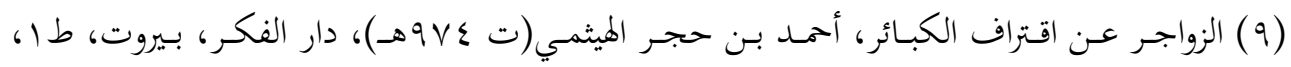


ورغم إجماع المسلمين على حرمة الربا، ووضوح الحكم على آكله بنص القرآن الذي جعله ظالمِا محاربًا لله ولرسوله، وبنص الأحاديث الشريفة التي جعلته ملعونًا

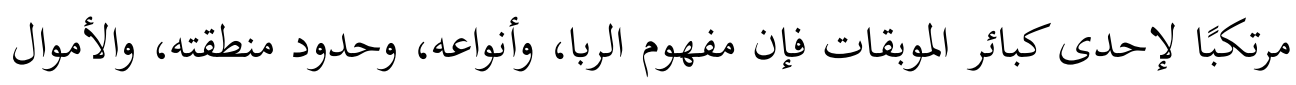

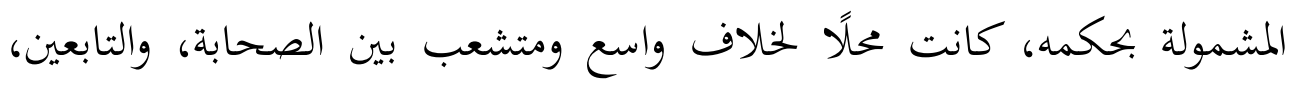

والمفسرين، والفقهاء، والعلماء منذ عصر صدر الإسلام حتى يومنا الحاضر (1). هـ ـ الحكمة في تحيمي الربا: الإسلام دين عظيم، يختار للإنسان ما فيه خيره، وحينما يحرم شيئًا يكون

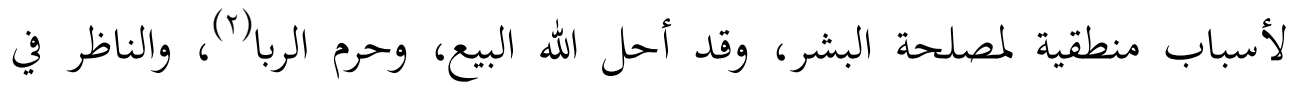

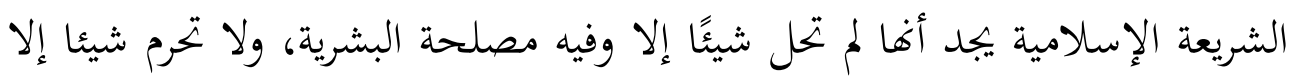
وفيه تعاسة البشرية وشقائها. ومن ثم فإن تحريم الشريعة للربا وسد المنافذ إليه جاء لتحقيق مصالح

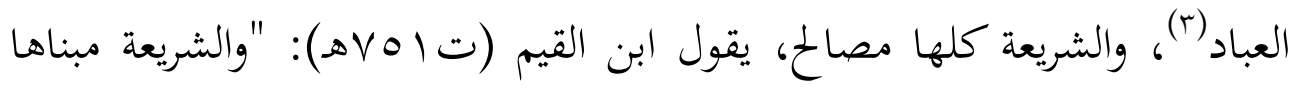

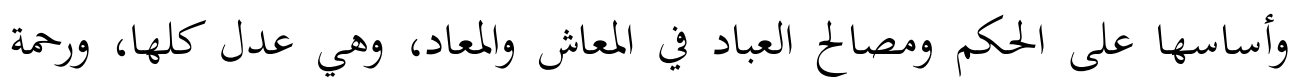

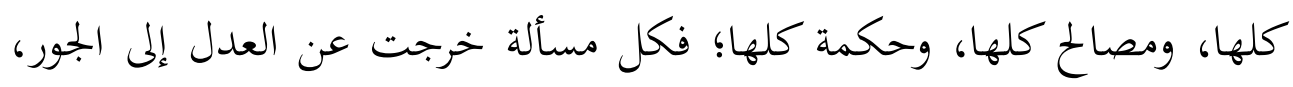
وعن الرحة إلى ضدها، وعن المصلحة إلى المفسدة؛ فليست من الشريعة، وإن أدخلت فيها بالتأويل؛ فالشريعة عدل الله بين عباده، ورحته بين خلقه، وحكمته إله الدالة عليه"(ع) فئن

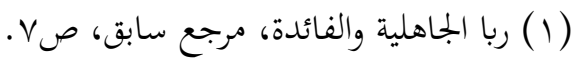

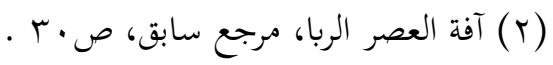

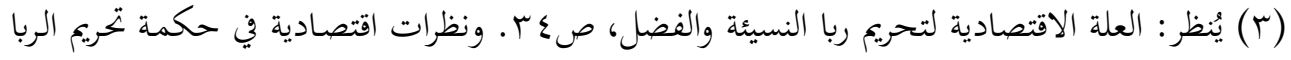

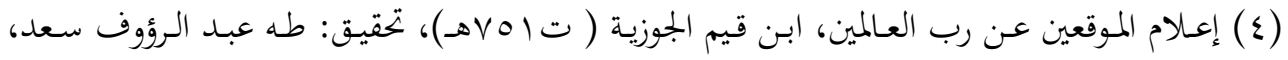

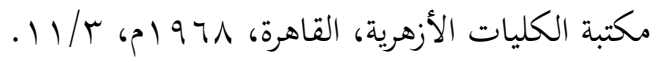


فالشريعة إذن ليست تعبدية، تحكمية، تحلل وتحرم دون أن تقصد إلى شيء وراء أمرها وهيها، وحظرها وإباحتها(')، والمصلحة التي قامت عليها الشريعة في

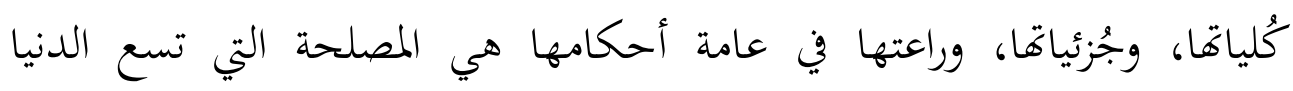
والآخرة، وتشمل المادة والروح، وتوازن بين الفرد والمجتمع، وبين المصلحة القومية

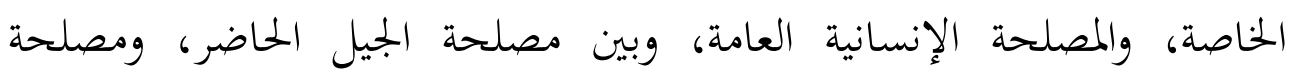

الأجيال المستقبلية(r).

ومن هنا نجد أن الحكمة من تحريم الربا تتلخص في النقاط التالية:

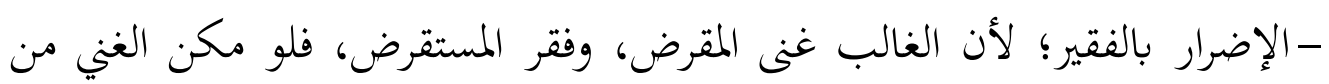
أخذ أكثر من المثل أضر بالفقير، يقول الدكتور عيسى عبده: "فإن إرهاقهم ـ أي

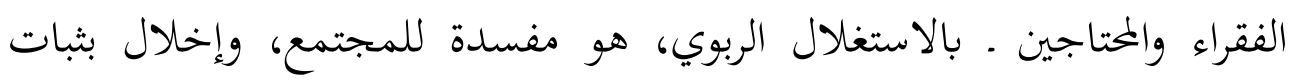
القاعدة التي كان ينبغي أن تتلقى العون، لا أن تستغل "(r). - انقطاع المعروف والإحسان الذي في القرض؛ إذ لو حل درهم بدرهمين ما سمح

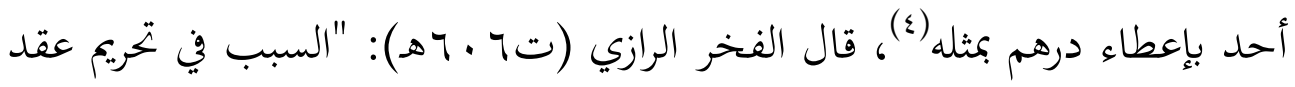
الربا أنه يفضي إلى انقطاع المعروف بين الناس من القرض؛ لأن الربا إذا طابت النفوس بقرض الدرهم واسترجاع مثله، ولو حل الربا لكانت حاجة المحتاج تحمله

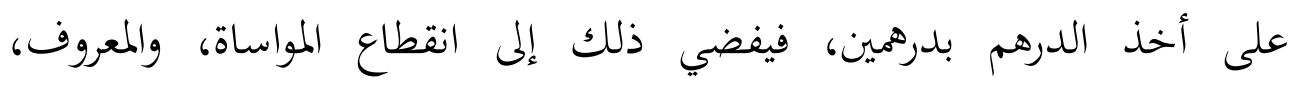

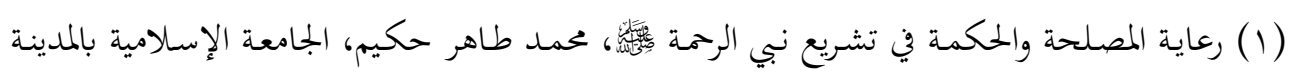

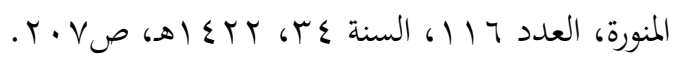

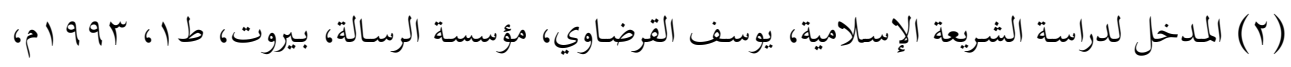

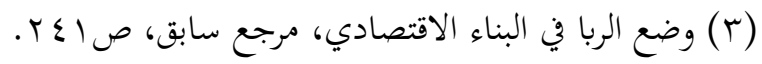

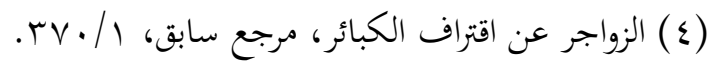


والإحسان"(1)، فالربا يقطع صلة المعروف، والقربى بين الناس، فما دام القرض الربوي، فلا مواساة، ولا معاونة، ولا إحسان(r).

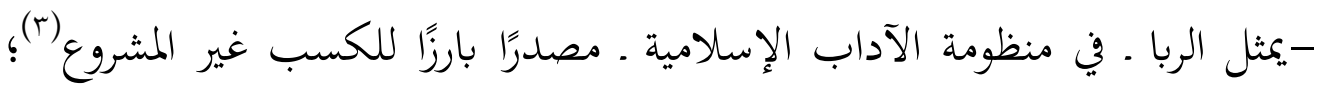

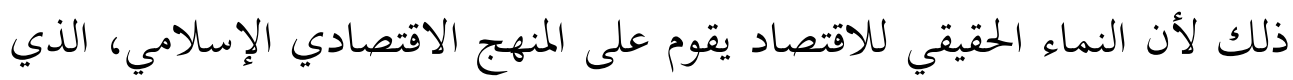
حث على الصدقات، والبذل، والعطاء، والإنفاق في سبيل الله (ع).

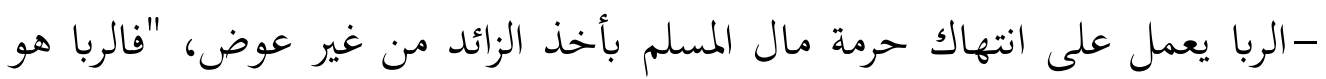
أكل مال يكسبه صاحبه بغير جهد أو بذل، وإنما بمجرد الانتظار، واستغلال حاجة المحتاج، أو باستغلال فرص القحط والجوع إذا انتشرت الفاقة(ه). - تعطل المكاسب، والتجارات، والعمارات، والصناعات، يقول ابن حجر الهيتمي (ت \& عهـ): "لو حل الربا لبطلت المكاسب والتجارات؛ إذ من يحصل درهمين بدرهم كيف يتجشم مشقة كسب، أو بتحارة، وببطلافما تنقطع مصالح الخلق؛ إذ إذإل

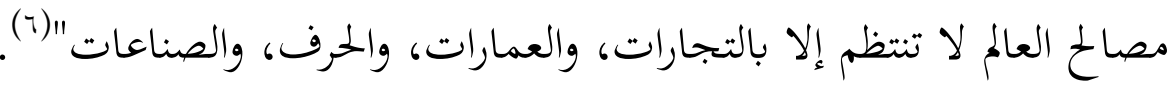

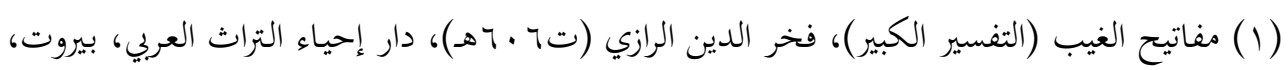

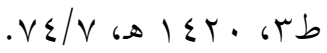

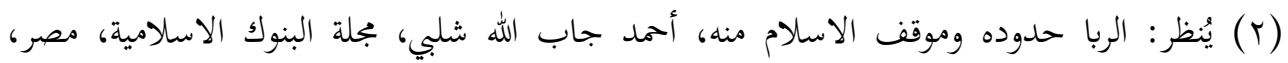

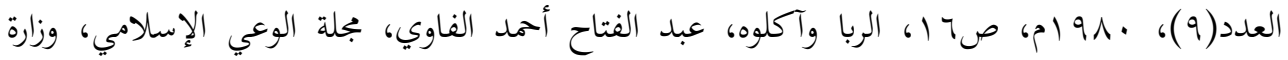

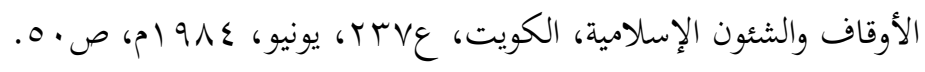

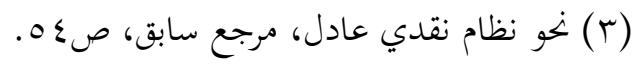

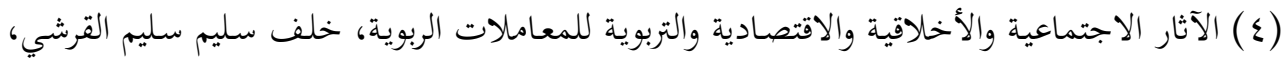

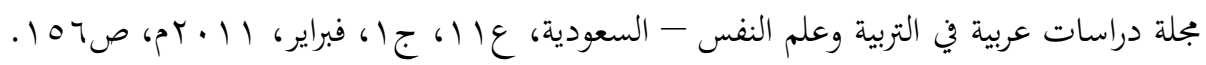

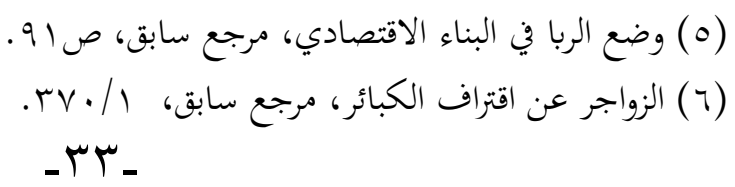


- الربا عمل غير إنتاجي، فالمال لا ينتج مالَا، وبالتالي فهو لا يزيد من ثروة

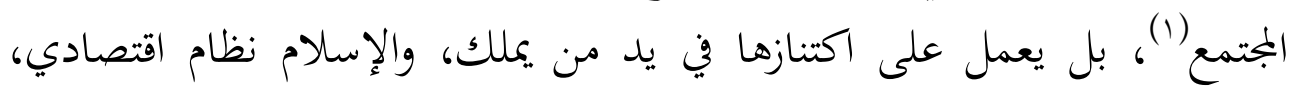

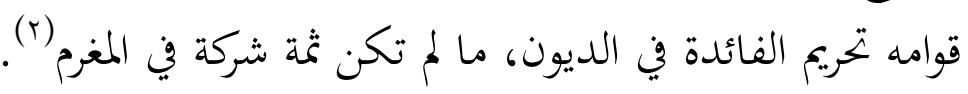

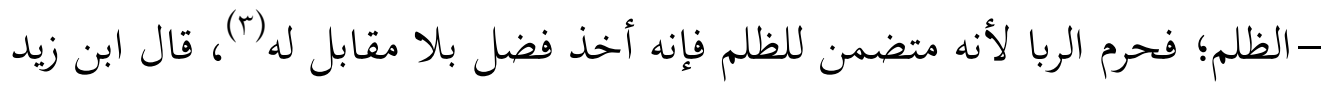

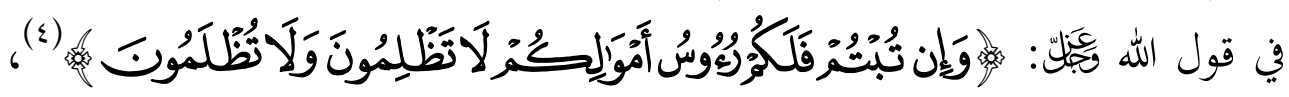

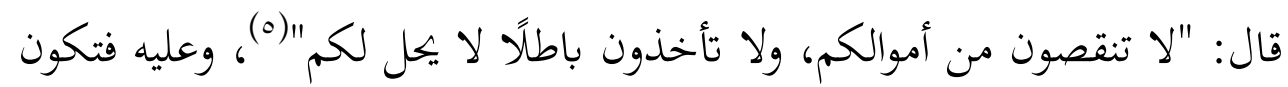

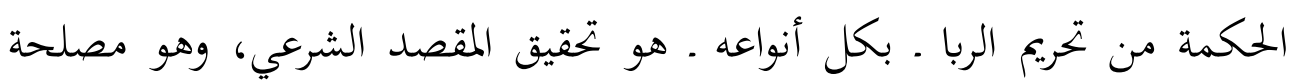
العدل، وتحريم مفسدة الظلم (؟). - دفع الغبن عن الناس، وعدم الإضرار بهم (v)، فيترتب على العلى الربا الإفلاس، وضياع

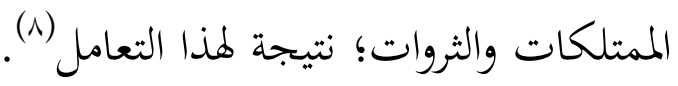

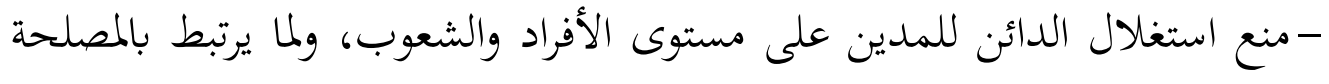

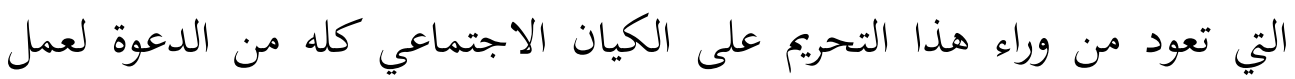

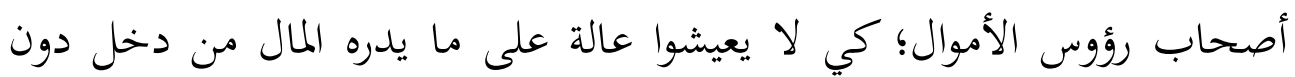
مقابل يبذلونه (9)

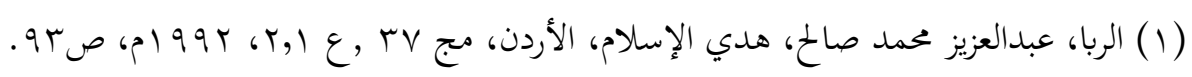

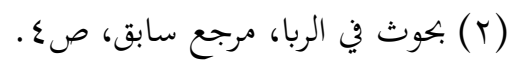

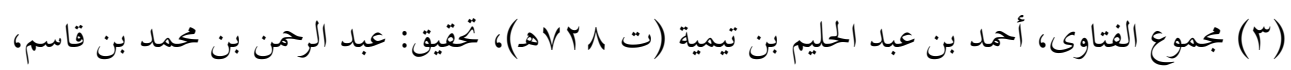

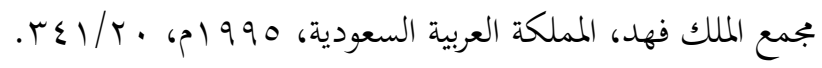

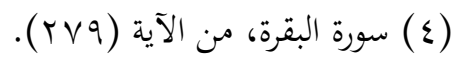

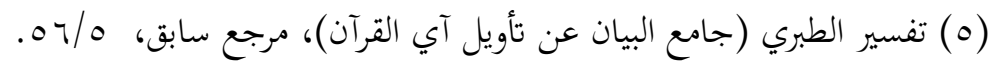

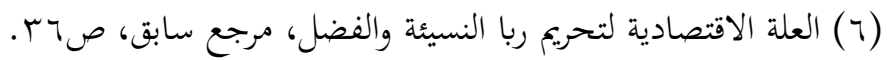

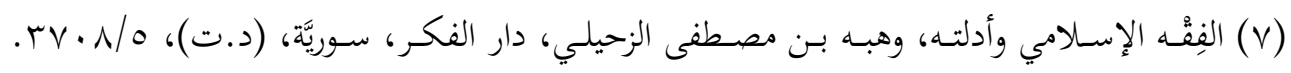

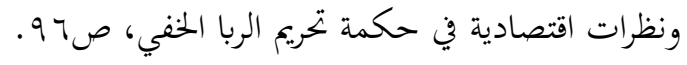

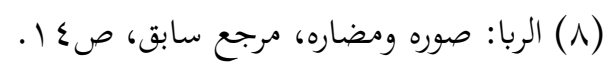

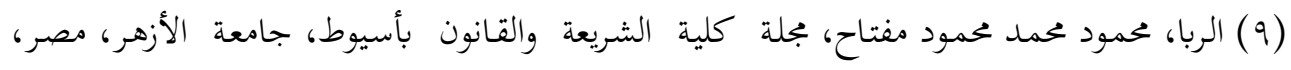

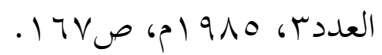


- أن تكون المعاملات في الشريعة الإسامية جارية في المجتمع الإسلامي على

الإنصاف، والعدل، والخلق الكريم، بعيدًا عن الاستغلال، أو الاستغفال للناس (1).

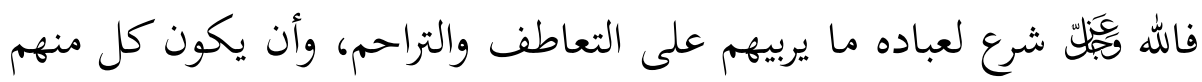
عونا للآخر، لا سيما عند شدة الحاجة؛ ولذلك حرم الربا، الذي هو استغلال

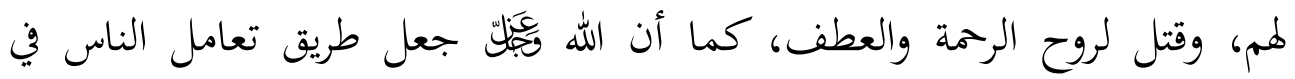
معايشهم قائمًا على أن يكون استفادة كل واحد من الآخر، في مقابل عمل يقوم به نهوه، أو عين يدفعها إليه، والربا خال من كل ذلك؛ لأنه عبارة عن إعطاء المال مضاعفًا من طرف لآخر، بدون مقابلة من عين ولا عمل (r).

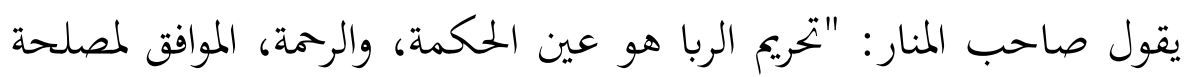

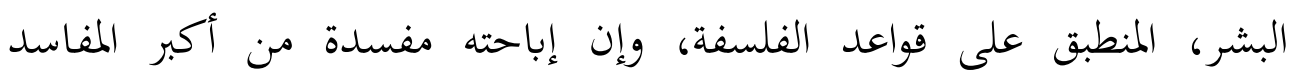

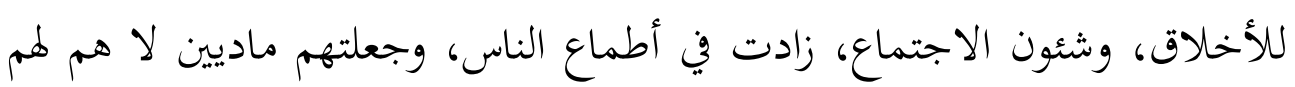

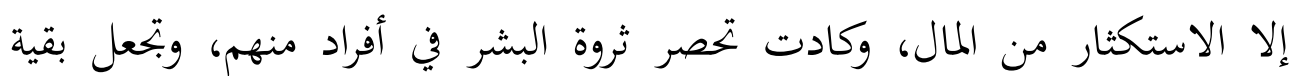
الناس عالة عليهم، فإذا كان المفتونون من المسلمين بهذه المدنية ينكرون من دينهم تحيم الربا بغير فهم ولا عقل فسيجيء يوم يقر فيه المفتونون بأن ما جاء به

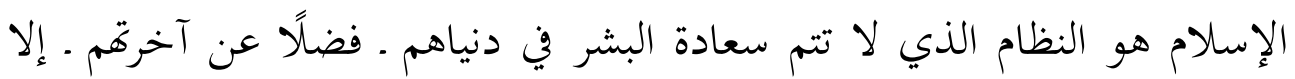

و ـ نشأة التعامل بالربا وتطوره:

بعيدًا عن سرد التفاصيل الدقيقة عن انتشار الربا في الحضارات الإنسانية

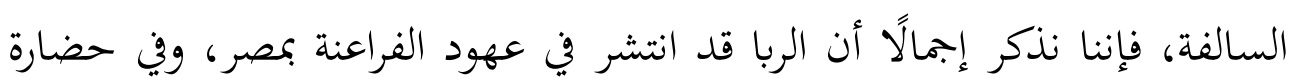

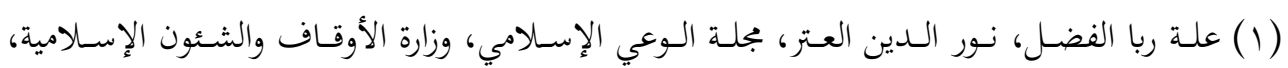

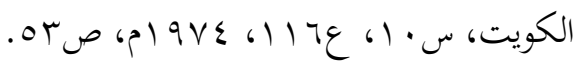

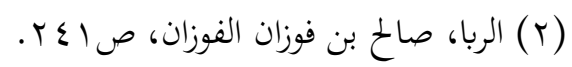

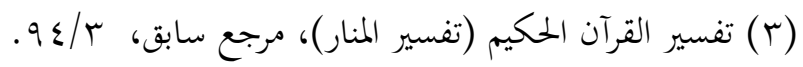

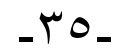


وادي الرافدين، وعند البابليين، وعند حضارة الهند القديمة، وعند الإغريق، وعند الرومان، وعند عرب الجاهلية قبل الإسلام. وقد ارتبط نُشوء نظام التعامل بالربا بنشوء تعامل الناس بالتجارة، سواء أكانت على نهو مقايضة سلعة بسلعة، أم على نهو معاوضة نقد بنقد.

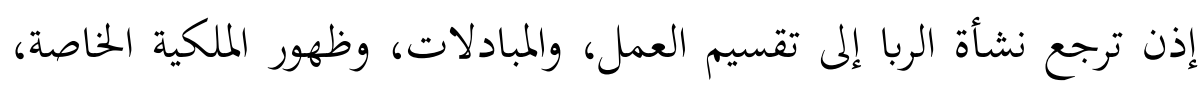
وقيام طبقات تتفاوت من ناحية المركز المالي. وقد مثَّل الربا دورًا مهما في اهيار المجتمعات البدائية، وظهور الاقتصاديات

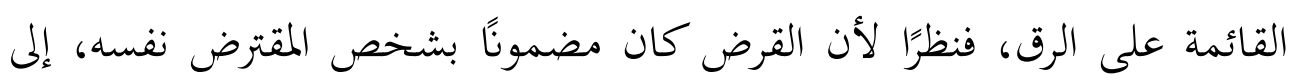

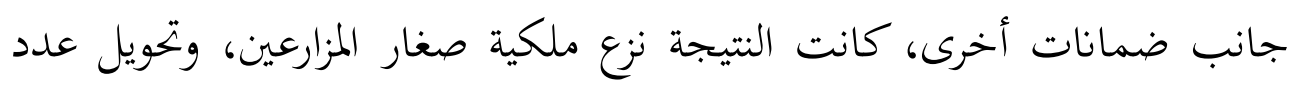
منهم غلة رقيق، مما أدى في النهاية إلى تركز الملكية العقارية في أيدي قلائل، وتميز

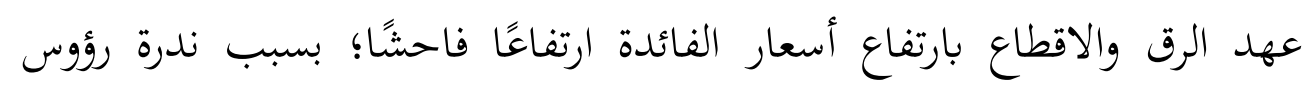
الأموال، وشدة الطلب عليها من جانب الأعيان والسادة(1). وقد انتشر الربا في الجزيرة العربية، عندما قدم اليهود إليها، وحملوا فكرة المراباة

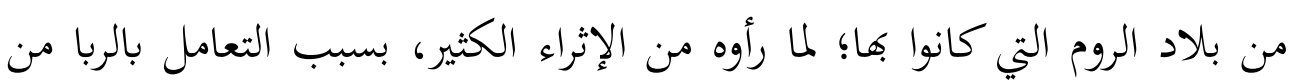
غير نصب، وجعلوا موطنهم سوقًا لرواجه، فاستفحل الربا بينهم وبين العرب، حتى إلى براء استغرقت الديون الرقاب، وباع الدائن مدينه، وأكرهوا فتياتم على البغاء؛ لقضاء

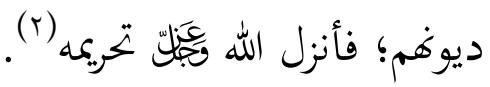
وقد ازدادت ضراوة هذه الحرب في العصر الحديث منذ أن وطئ الاستعمار المنطقة الإسلامية، وجلب معه بنوكه الربوية؛ لتعمق التناقض بين عقيدة المرء

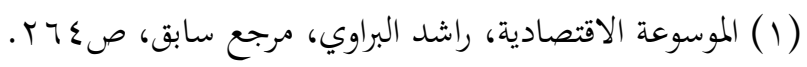

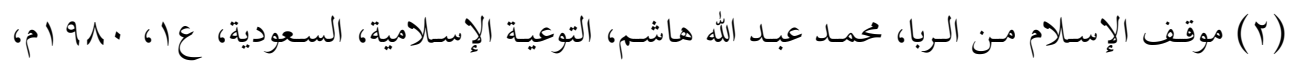


وممارساته العملية في الحياة بعد أربعة عشر قرنًا مضت على العالم الإسلامي، لا

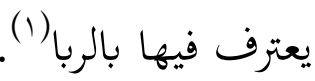
ولو عاد الناس إلى حظيرة الأديان السماوية فسيجدوها قد أجمعت على له

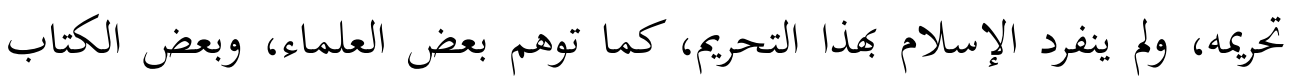

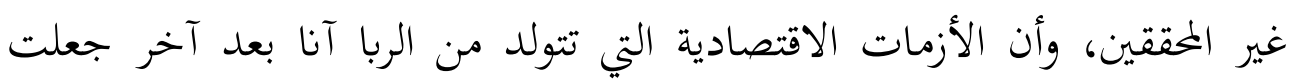
الاقتصاديين يفكرون في إلغائه. وخلاصة الأمر فلم يحرم الربا في ديانة الإسلام وحدها من بين الديانات

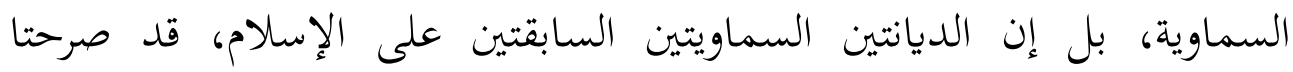
بالتحريم فيهما، فهو محرم في التوراة، والإنجيل، والقرآن، لا في القرآن وحده، ولانال تزال بقية من هذا التحريم في التوراة التي بأيدينا(؟).

(1) لماذا حرم الله الربا، مجد الدين عزام، مجلة البنوك الاسلامية، مصر، العددوه، رجب، 911 (م)، 


\section{المبحث الأول}

الحفاظ على وظيفة النقود وسلامتها وزيادة سرعة دوراها وعدم اكتنازها

\section{وتوسيع حجم المبادلات بما في ظل اقتصاد حقيقي}

النقود هي أي شيء يستخدم من قبل الأفراد، ويلقى قبولاً عامًا كوسيط

للتبادل Medium of exchange في المعاملات الاقتصادية، ويصلح في الوقت ذاته

لقياس القيم، وحفظ الثروة، وتسوية الديون والالتزامات (1).

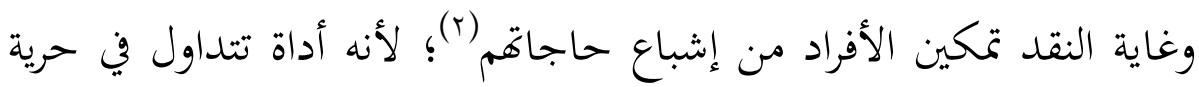

من حائز إلى حائز آخر، داخل المجتمع الاقتصادي، سدًا لقيمة السلع، أو سدادًا

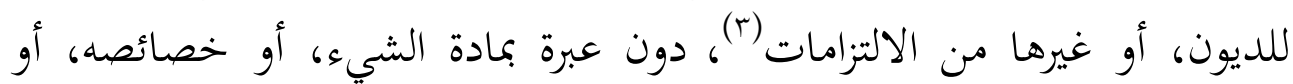
الجهة التي تقوم بإصداره.

والنقود هي دماء الاقتصاد، والنقود السلمية هي التي تجعل الاقتصاد سليمًا، والتدهور في قيمة النقود بسبب الفوائد المرتفعة يرجع إلى سياسات اقتصادية فاشلة، هذه السياسات تدور حول تقليص حجم أو كمية النقود في الدول، في حين تتسع كمية النقود من خلال القروض الممنوحة دوليًا، يقول فرايهرفون بتمان:

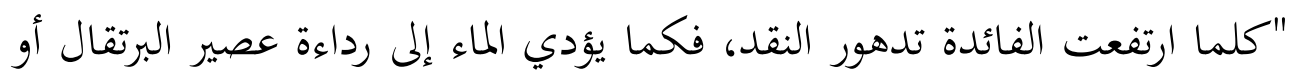
الحليب، فإن الفائدة تؤدي إلى رداءة النقود؛ فالفائدة العالية تدمر قيمة النقود، وتنسف أي نظام نقدي، ما دامت تزيد كل يوم، وتتوقف سرعة التدمير وحجمه

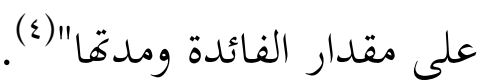
كما أن الربا يؤدي إلى تركز النقود بأيدي قلة قليلة، وهذا التركز يؤدي إلى

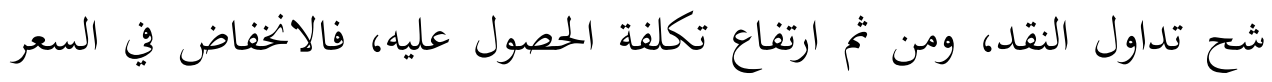

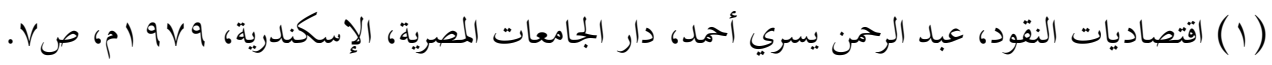

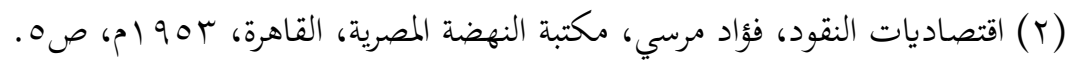

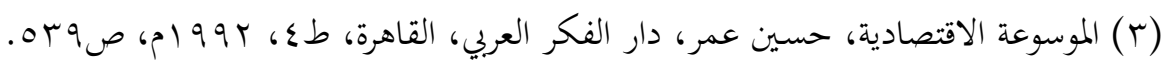

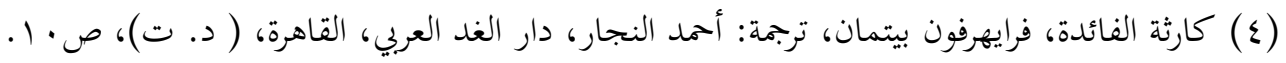


النقدي للسلع • في هذه الحالة ـ ضار بالاقتصاد؛ لأنه ناتج عن انكماث تداول

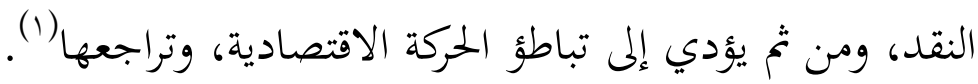

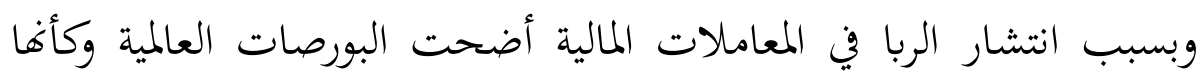

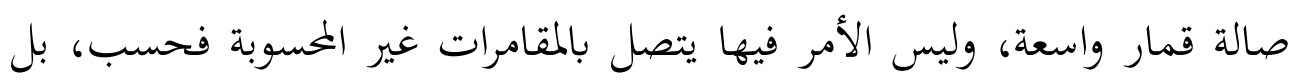
إن هناك من يبيع دائمًا ما لا يملك، ومن يشتري من دون أن يدفع ثمنًا، والفائدة الملعونة هي المسئولة عن المصائب الكبرى في النظام النقدي العالمي، وهي المسئولة عن التضخم، وعن ضياع الأموال، وعن عجز دفع المدينين ديوغم (r). إن النمو الحقيقي للاقتصاد لا يكون بالتعامل بالربا، وتعاطي الفوائد الربوية،

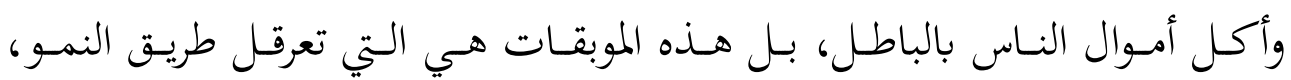

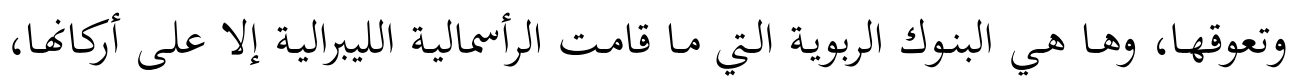

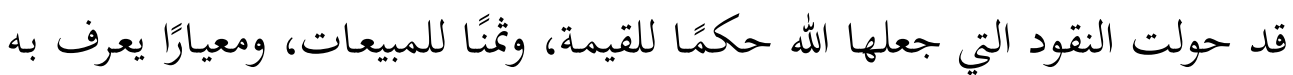

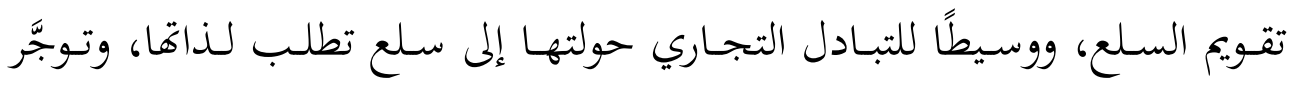

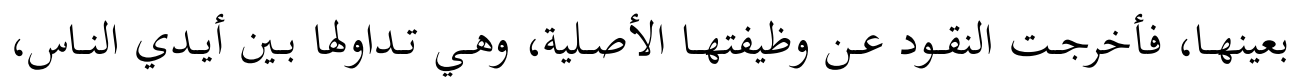
وعدم اكتنازها، أو تعطيلها (r). يقول ابن القيم (ت ا ه Vهـ): "فإن الدراهم والدنانير أثمان المبيعات، والثمن

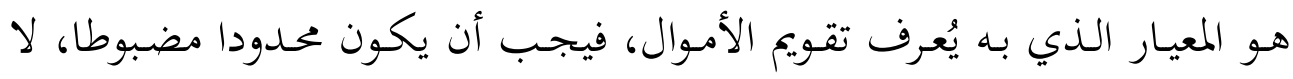

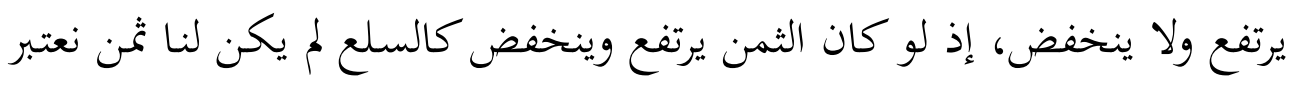
بـه المبيعات، بل الجميع سلع، وحاجة النـاس إلى ثمن يعتبرون بـه المبيعات حاجـة

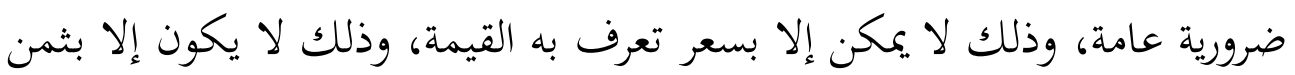

(1) اقتصاديات ربا الفضل: نحو نموذج تحليلي موحد لأنواع الربا، سامي بن إبراهيم السويلم، بجلة جامعة

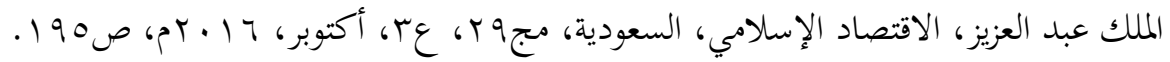

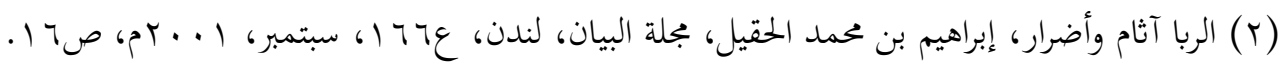

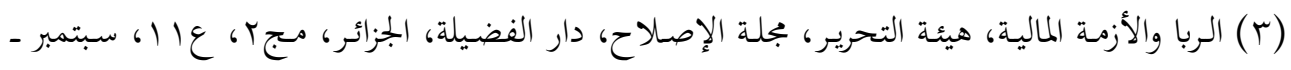

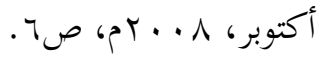


تقوم بـه الأشياء، ويستمر على حالة واحدة، ولا يقوم هو بغيره، إذ يصير سلعة

يرتفع وينخفض؛ فتفسد معاملات الناس، ويقع الخلف، ويشتد الضرر" (1). إذن لكي تقوم النقود بوظائفها الأساسية كوسيط في التبادل يجب أن تقوم بوظيفتها كمقيـاس للقيمة، فتنسب إليها جميع السلع في السوق، حتى يمكن أن يتم تبادلها بالنقود على هذا الأساس (r)، فالنقود تكون صحيحة وسليمة إذاكانت

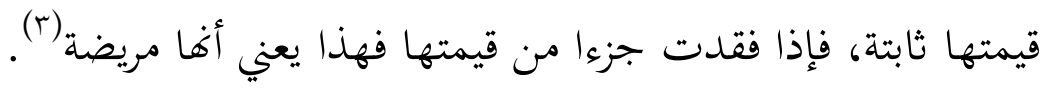
فللنقود وظيفـة محددة، كما أن للأقوات وظيفـة محددة أيضًا، وكذلك سـائر

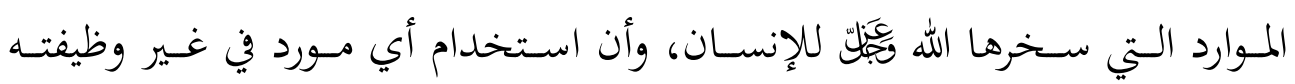
الأساسية يعد تعديًا؛ لأنه يؤدي إلى آثار سيئة على الإنسان والبيئة.

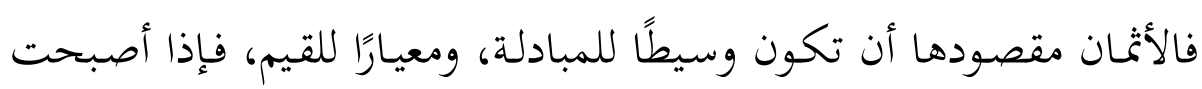

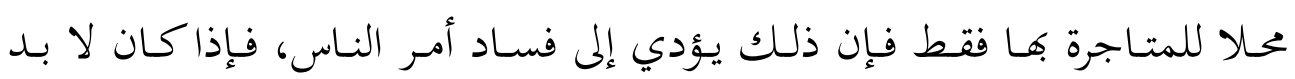

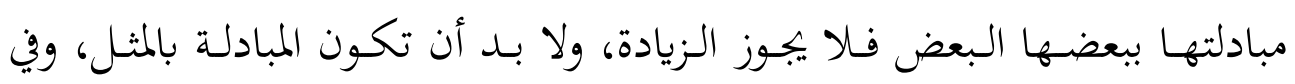

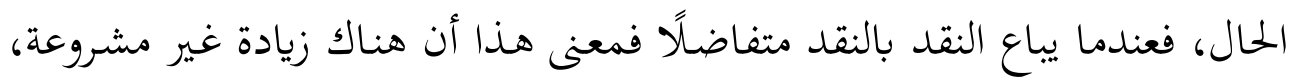

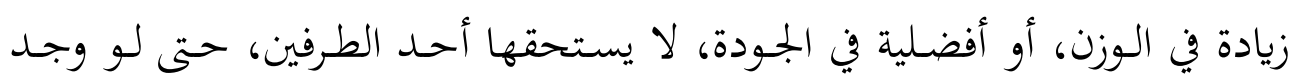

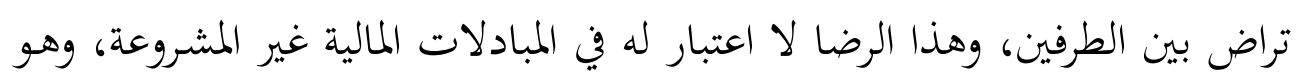
ناجم إما عن غش، أو خديعة، أو غفلة من أحد الطرفين (ع).

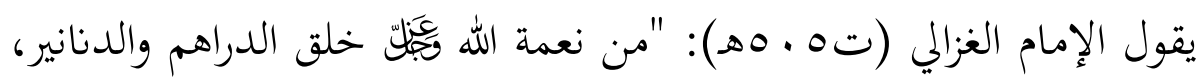
وبهما قوام الدنيا، وهما حجران لا منفعة في أعياها، ولكن يضطر الخلق إليهما من

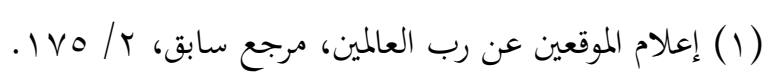

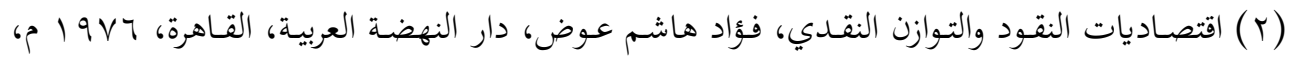


حيث إن كل إنسان محتاج إلى أعيان كثيرة في مطعمه، وملبسه، وسائر حاجاته، فلا بد بينهما من معاوضة، ولا بد في مقدار العوض من تقدير "(1).

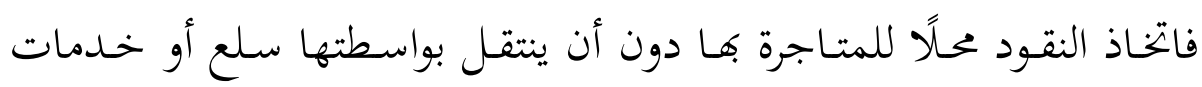
معناه تعطيل لمذه النقود؛ وبالتالي تضييق للمبادلات الحقيقية في المجتمع، وعرقلة

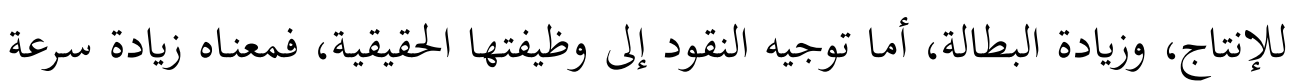

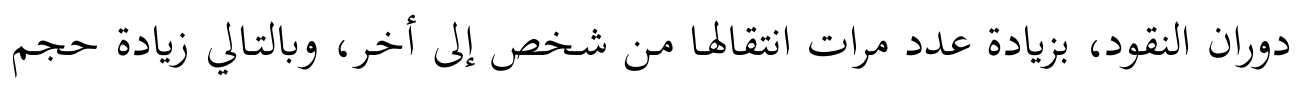

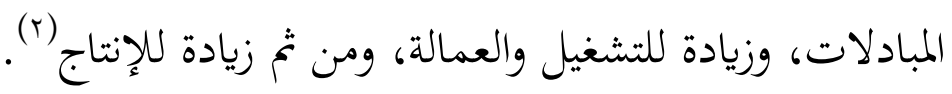

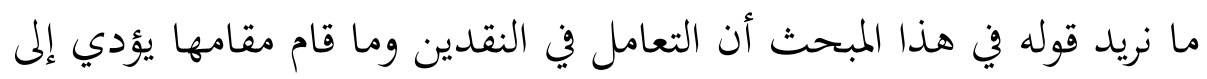
أن تكون سلعًا تباع وتشترى، وعُرضه للزيادة والنقصان، والارتفاع والانخفاض، بما وليا يتفق مع العرض والطلب (r).

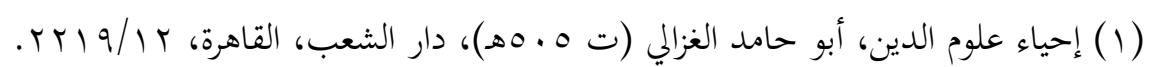

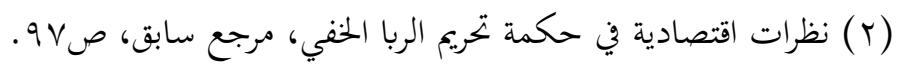

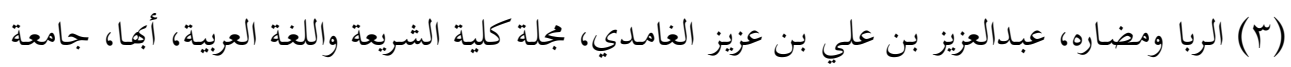

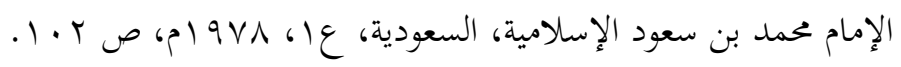
$-\varepsilon 1$ - 


\section{المبحث الثاين}

الإسهام في التخلص من ظاهرة التضخم والغلاء الفاحش الفي

\section{للسلع والمنتجات في ظل اقتصاد حقيقي}

التضخم Inflation يعني زيادة مفاجئة وحادة في الأسعار، وانخفاضا مستمرا في قيمة العملة(1)، وهو وضع يتسم بأن القوة الشرائية تنطلق في الأسواق بأسرع

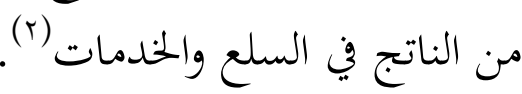
وهذا يعني أن النقود غير قادرة على القيام بـدورها، كوحدة حساب عادلة

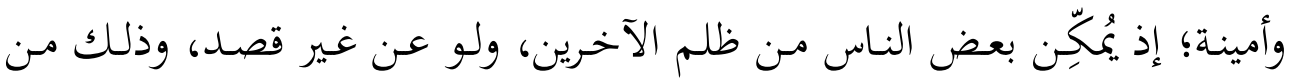

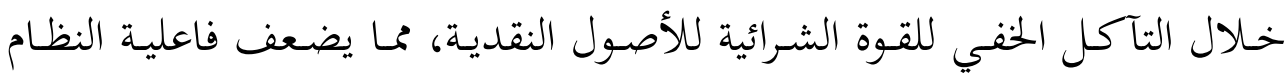
النقدي، ويزيـد مـن الاستهاكك، ويؤدي إلى سوء تخصيص الموارد، ويفسـد القيم، ويزيد من حدة الفروق في دخول الأفراد"(r).

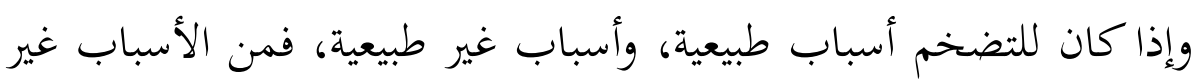
الطبيعية للتضخم الربا، فالمرابي بما يقرضه من فائدة مرتفعة يجبر أصحاب السلع والخدمات على رفع أثمان هذه السلع والخدمات، ولا شك أن التضخم يسيء إلى إلى

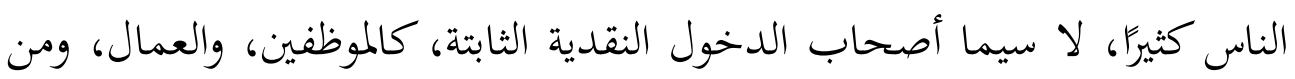

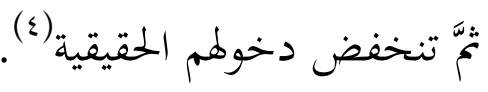

(1) يُنظر : معجم مصطلحات الاقتصاد والمال وإدارة الأعمال ( إنجليزي . عربي )، نبيه غطاس، مكتبة

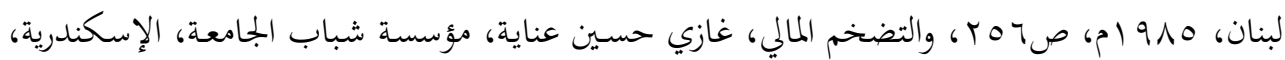

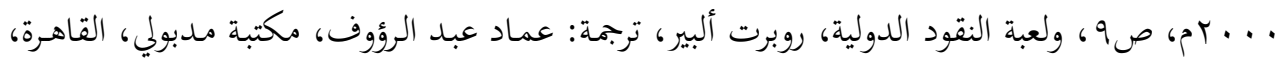

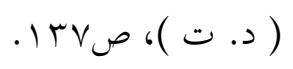

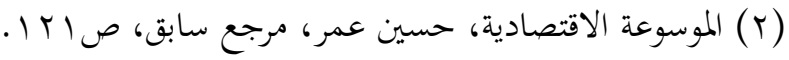

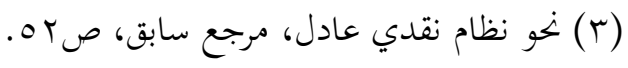

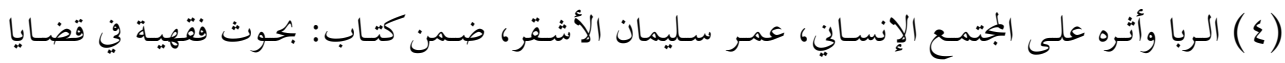

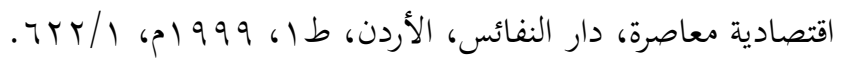


كما أن التمويل عن طريق الفائدة هو الأب الحقيقي للتضخم (1) يقول فرايهرفون بيتمان: "كلما ارتفعت الفائدة تدهور النقد، فالفائدة العالية تدمر النقود، والفائدة تعد عالية إذا زادت عن معدل الإنتاجية في المجتمع، أي: إذا زادت عما أضافه استخدام النقود من زيادة حقيقية في الإنتاج، فكل زيادة في الفوائد عن معدل الزيادة في الإنتاجية معناه حقن التضخم بمزيد من الجرعات المنشطة" (r) (المواند

وما يحدث في العالم اليوم من غلاء الأسعار، يرجع سببه ـ في أغلب الأحيان . إلى النظام الربوي السائد اليوم، فصاحب المال لا يقبل أن يبيع سلعته أو الشيء

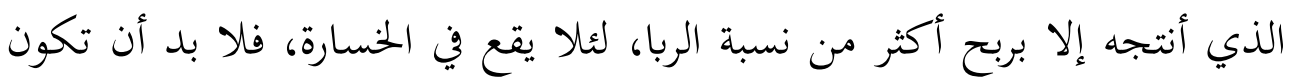

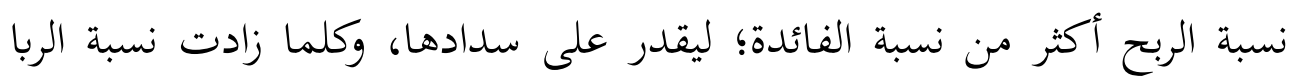
غلت الأسعار، وإذا كان المنتج أو التاجر ممن يقترض بالربا فلا بد له من رفع

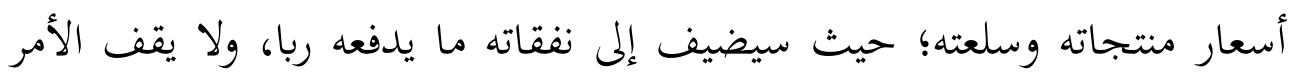
عند غلاء الأسعار، بل يحدث اضطراب في حياة الناس؛ حيث لا يتمكنون من شراء حاجاقم الأساسية، بسبب غلاء الأسعار (r).

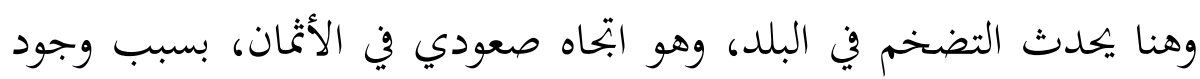
طلب زائد أو مرتفع، فالمرابي بما يقرضه من فائدة مرتفعة (كبعض البنوك) يجبر

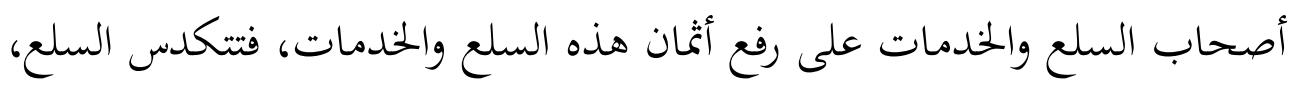
وتزداد البطالة، ويزيد العرض على الطلب، وتحدث البطالة والتضخم.

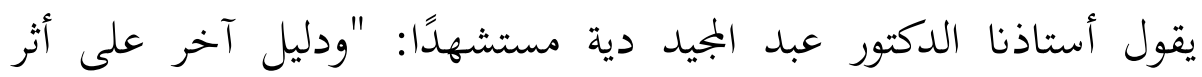

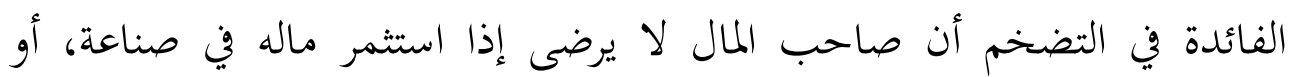

(1) يُراجع: النقود والبنوك والتجارة الخارجية، جلال القصاص، الدار الجامعية، الإسكندرية، • ا • بم.

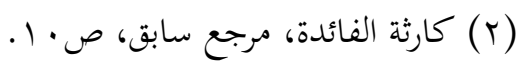

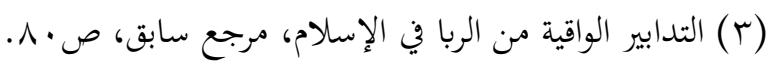
- $\varepsilon$ ـ 
زراعة، أو شراء سلعة أن يبيع سلعته، أو الشيء الذي أنتجه إلا بربح أكثر من

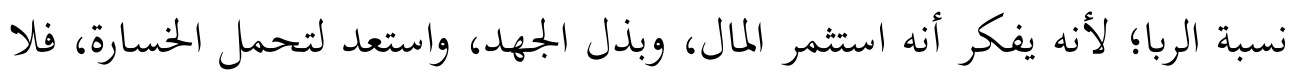
بد أن تكون نسبة الربح أكثر من نسبة الربا، وكلما ازدادت نسبة الربا غلت الأسعار أكثر منها بكثير، هذا إذا كان المنتج أو التاجر صاحب مال، مال، وأما إذا

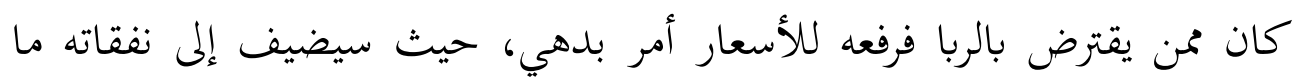
يدفعه من الربا"(1) - (1) ولا يقف الأمر عند غلاء الأسعار، بل يحدث اضطراب في حياة الناس؛ حيث لا يتمكنون من شراء حاجاهم الأساسية، بسبب غلاء الأسعار، فالفائدة

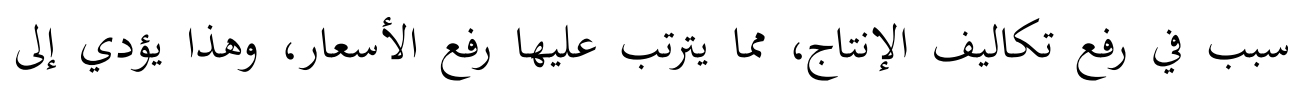
أضرار محققة على الناحية الاقتصادية. 


\section{المبحث الثالث}

\section{توقف عملية تعطيل أموال المسلمين}

والتحرز من استخدامها بصورة عكسية عليهم وإضرارهم بما

إن الفائدة من العوامل المعطلة للطاقات البشرية المنتجة، فضلا عن تعطيل

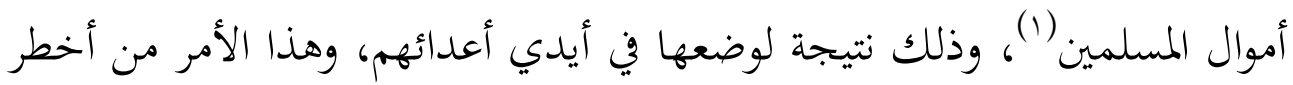

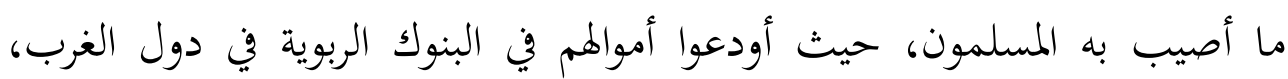

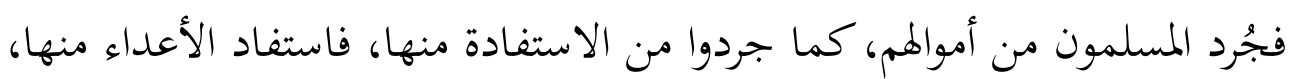
وطوروا دولمم، وعاشوا الرفاهية الاقتصادية، وعانى غيرهم الفقر والعوز، لا سيما مع تعطيل فريضة الزكاة، والاعتماد على العوائد الربوية، من تلك الودائع البنكية في بنوك الدول الأجنبية(r).

إذن يؤدي النظام الربوي إلى وقوع الدول الفقيرة تحت سيطرة الدول الغنية، بسبب تراكم فوائد القروض، ويقود هذا إلى الاستعمار العسكري، والاقتصادي، إدون،

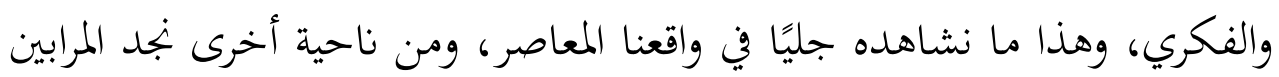
يسيطرون على سياسات الدول، ومؤسساقامَ(r). فمن أخطر ما أصيب به المسلمون أفم أودعوا الفائض من أموالهم في البنوك وكؤك

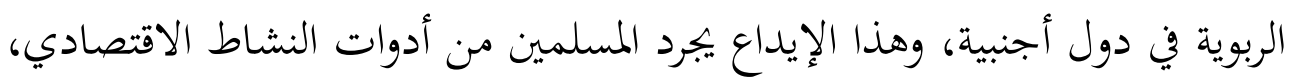
ومن القوة الظاهرة في المبادلات (ع).

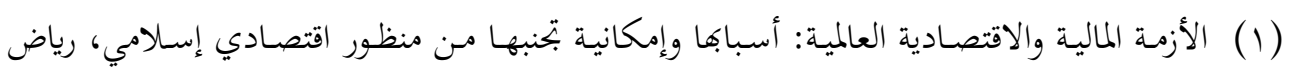

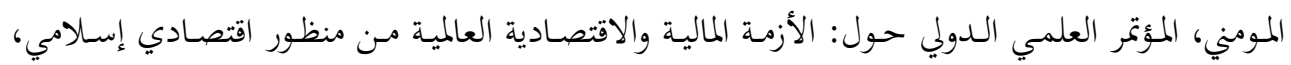

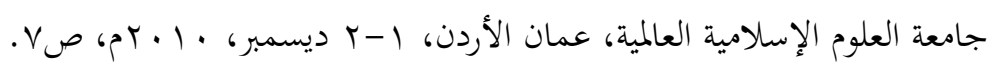

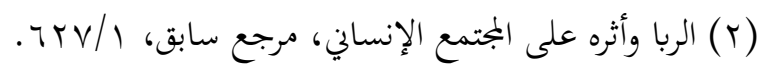

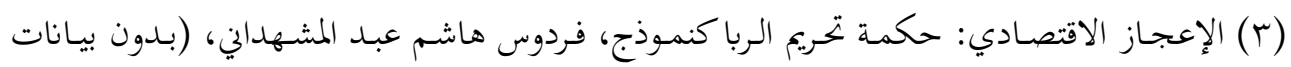




\section{المبحث الرابع}

التخلص من سياسة التبعية وذُل الاستعمار الفكري والاجتماعي الرابع

$$
\text { والاقتصادي والسياسي والعسكري }
$$

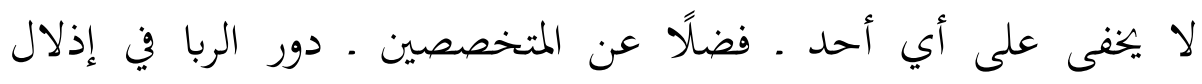

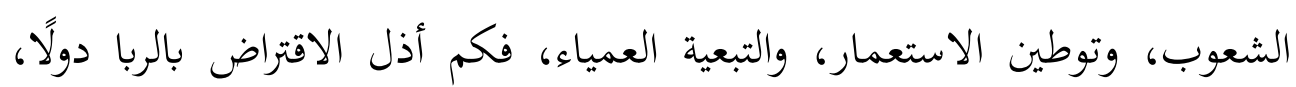
وأوقعها في ذل الاستعمار (1).

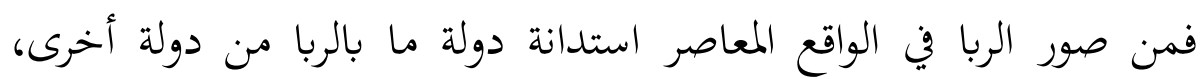

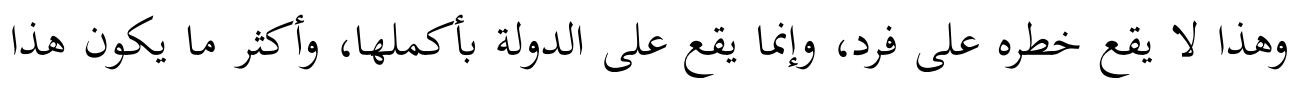

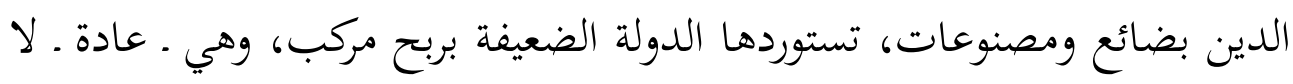

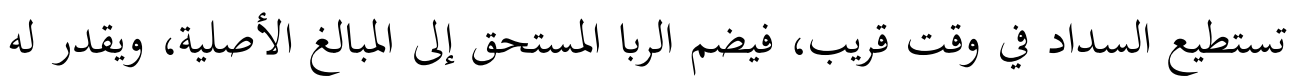

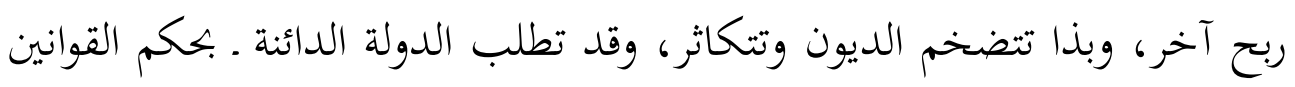

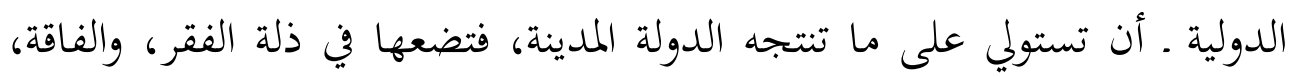
إلى زمن طويل، وهو لون من ألوان الاستعمار.

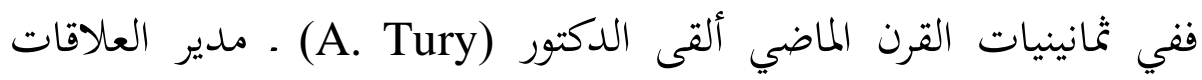

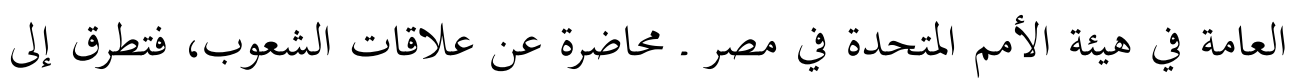

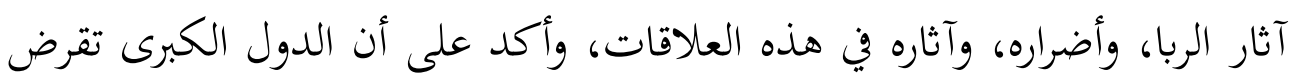

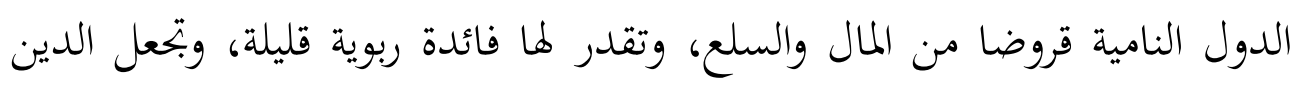

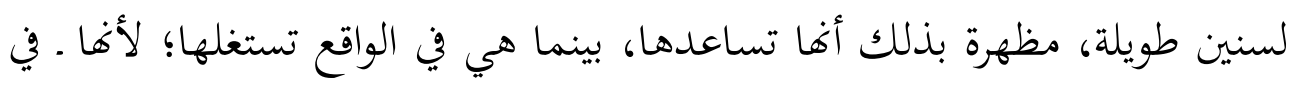

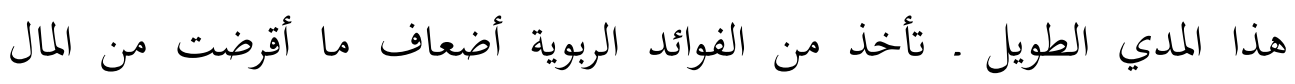

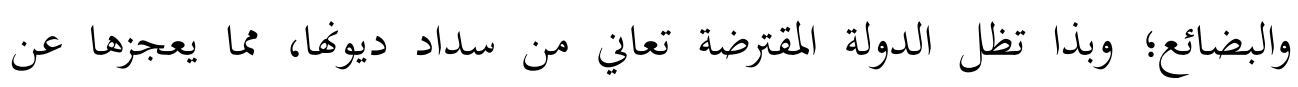
التقدم (r).

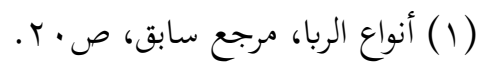

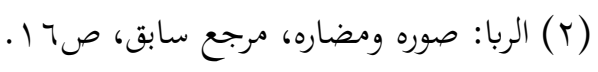


والحقيقة فإنه منذ دخل الاستعمار ديارنا ونحن نتعامل بالربا، ولم نخرج من دائرة التخلف إلى التقدم، ولم نصل من الاكتفاء الذاتي في زراعة، أو صناعة، وما

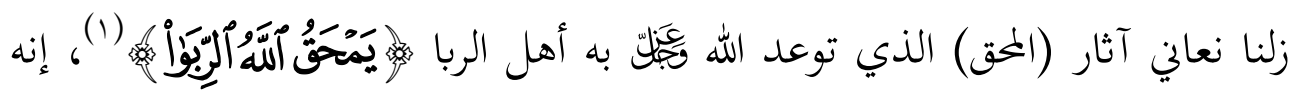

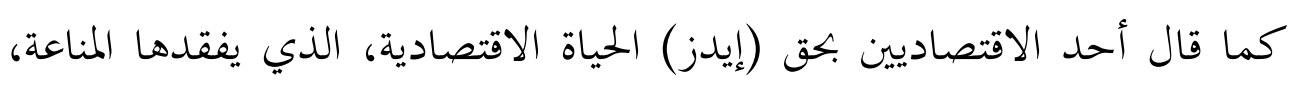
ويهددها بالهاكك والدمار (r) هذا في الوقت الذي فرض الإسلام التعاون بين الجماعات والدول، كما

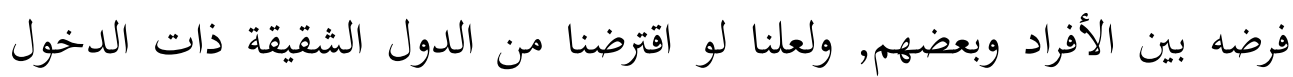

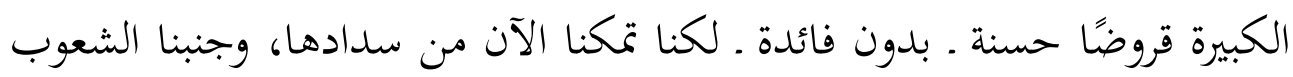
كل هذا العناء، ونحن الآن نتحمل أعباء الأرباح الربوية أضعاف المبالغ التي

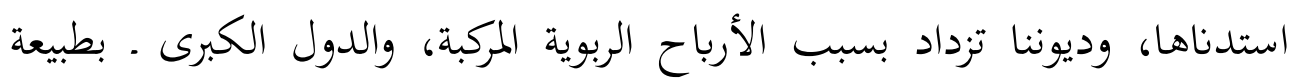
وضعها وسياستها ـ دول مستغلة، يهمها أن تظل الدول الصغرى سوقا لبضائعها، وهى لا تبالى بما تغرس في نفوس الشعوب الصغرى من أحقاد، وما تزرع في قلوبها من ضغائن. (r) من لأن والإسـلام حـث على إيجـاد عوامـل الوحسدة بـين المجتمع الإسـلامي، وتقويـة

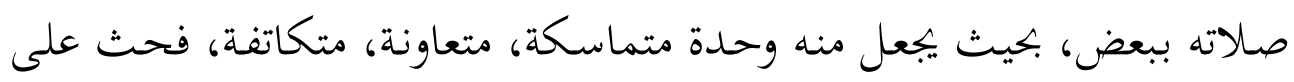
كل ما من شأنه تقوية روابط أفراد المجتمع ببعضه، من من تكافل اجته اجتماعي، يتمثل في

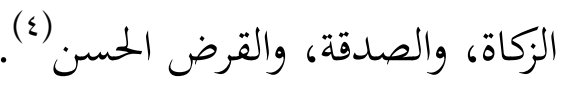

$$
\begin{aligned}
& \text { (1) (Yورة البقرة، من الآية(YVY) (Y ). }
\end{aligned}
$$

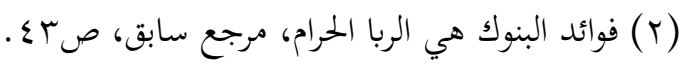

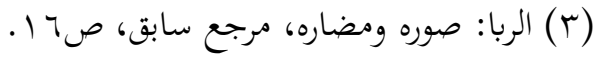

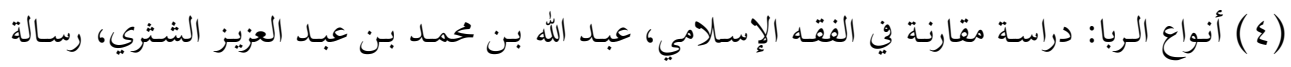

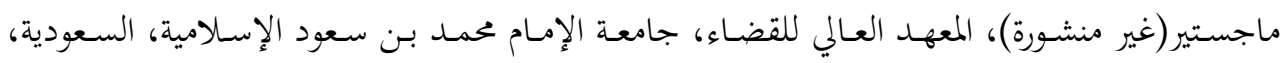


وفي وقتنا الحاضر استدانت الكثير من الدول؛ لمواجهة ظروف صعبة مرت

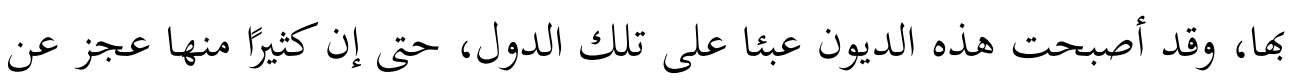
السداد، فني أغسطس من عامبو أو ام أعلنت المكسيك أها لن تستطيع دفع ديوها البالغة • م بيليون دولار، وبعدها أعلنت البرازيل عجزها عن سداد ديوها

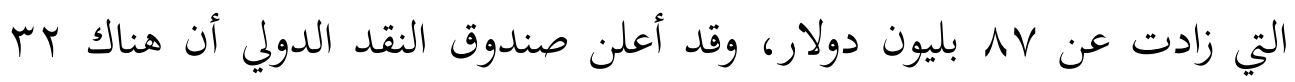

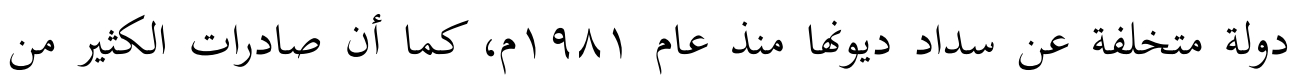
هذه الدول لا تفي بدفع خدمة الدين، وأصبحت وكأفا مزرعة يعمل فيها الناس لحساب المرابين الدوليين، والمرابون الدوليون أشد ضراوة من الأفراد؛ لأن محاولة القضاء على فرد أقل تأثيرا في المجتمع من محاولة القضاء على أمة بأسرها (1). ومن ناحية أخرى فالربا وسيلة للضغط السياسي، فالدولة إذا ضعفت فرئ

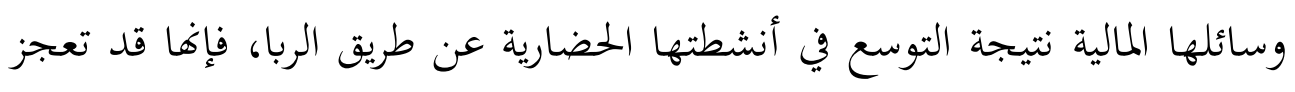
عن سداد الفوائد المفروضة عليها، نتيجة الديون، فضلاً عن أصل الدين المتراكم عليها، وهذا العجز المالي يساعد على سيطرة الدول الدائنة على الدول المدينة،

$$
\text { والانحياز لها في كل شئوها، وهان. }
$$

فكم أذل الربا شعوبًا ودولًا كانت لها لها العزة والمنعة، فوقعت بسبب الربا في

الدين، وتحت وطأة الأعداء(r)، ولقد وضع الغرب أنظمة الربا ليتيسر له الحصول

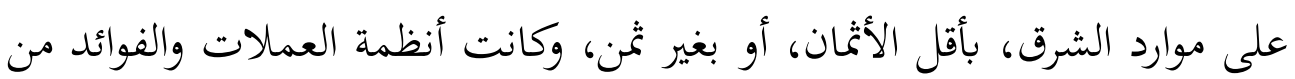

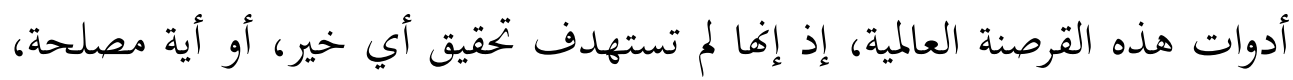

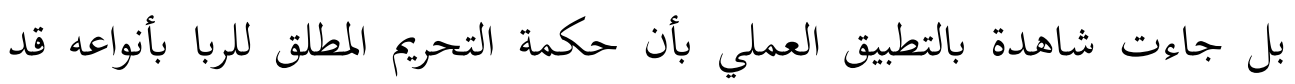

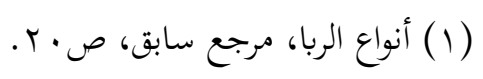

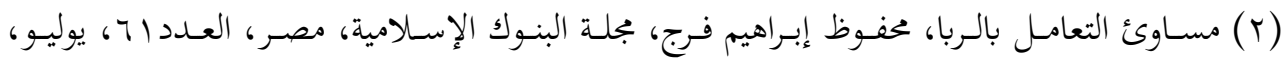
1911 19، صדr. (r) الربا، صالح سالم النهام، بجلة الوعي الإسلامي، وزارة الأوقاف والشئون الإسلامية، الكويت، العدد

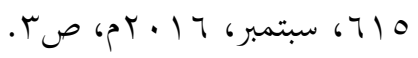


غابت عنا، فما من أمر أو فهي جاءت به الشريعة إلا وفيه مصلحة ظاهرة، قد يتعسر فهمها أحيانا، ولكنها حقيقة لا محالة (1). وقد اضطر النظام الربوي في الدول النامية إلى الاستدانة من الدول المتقدمة لأجل برامج التنمية، وقد حصلت هذه الدول على الديون بشروط ربوية، طبقًا للنظام الاقتصادي السائد، وبلغت الديون ـ بسبب السحر الربوي ـ مبلغًا اضطرت الدول المدينة إزاءها للاستدانة مرة أخرى لأجل دفع الفوائد على الديون الديون

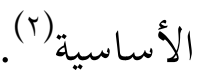
وخلاصة الأمر فالكثير من دول العالم الإسلامي بات مكبلا بالديون وأعباء خدمتها، التي تقتطع أجزاء ضخمة من مواردها المالية، وهددت استقالالها

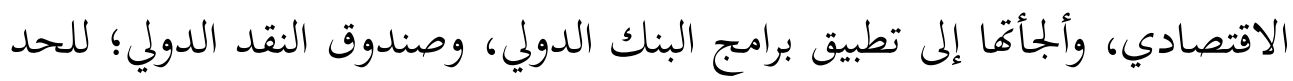
من مديونيتها؛ فأثرت سلبًا في أهداف التنمية البشرية، من حيث تخفيض النيف الدخول

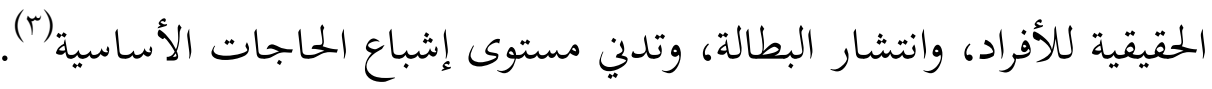

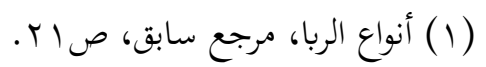

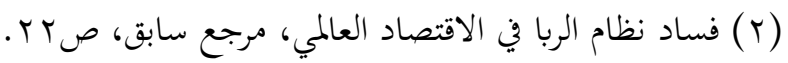

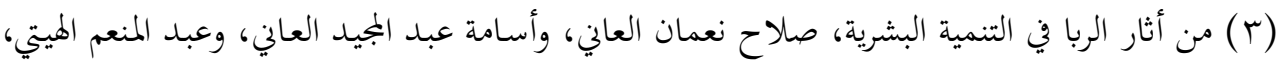

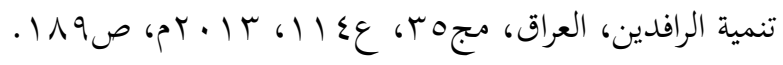
$-\leqslant 9$ - 


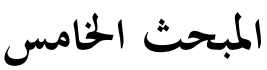 \\ الحد من زيادة الأعباء على المستهلكين والمطحونين وذوي الطبقات الفقيرة}

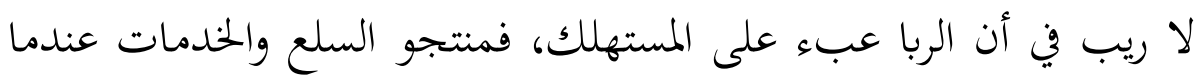

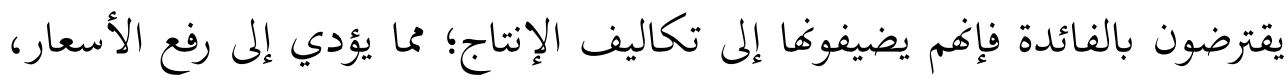

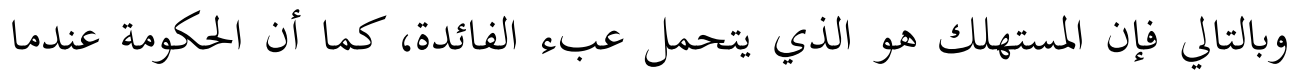

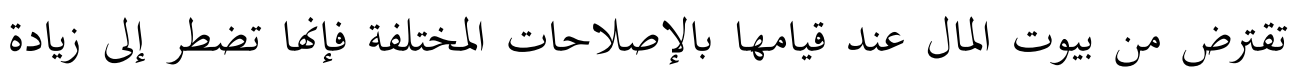
الضرائب؛ وبذلك يشترك كل فرد في دفع الجزية للمرابين (1).

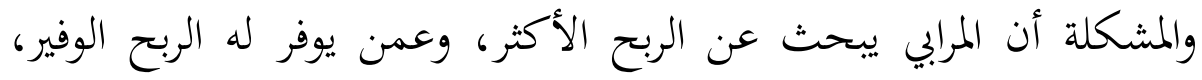

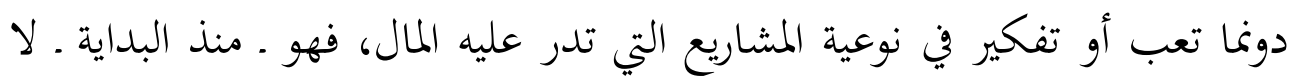

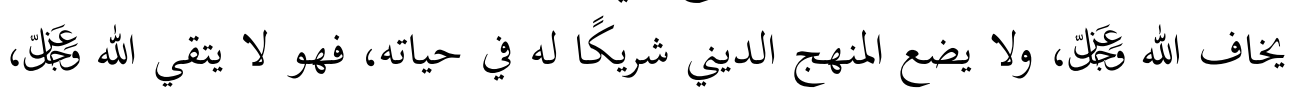

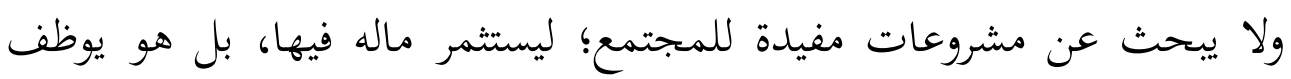

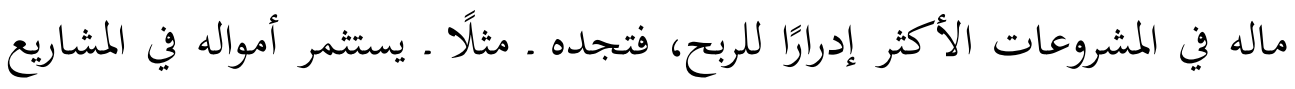

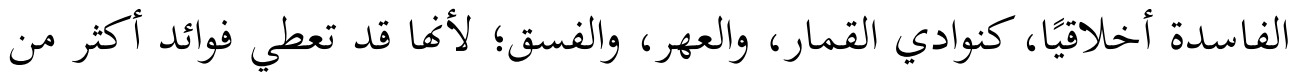

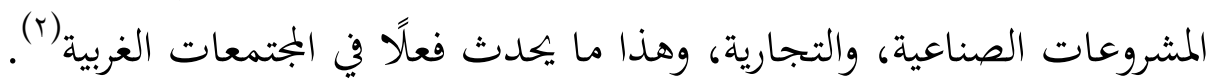

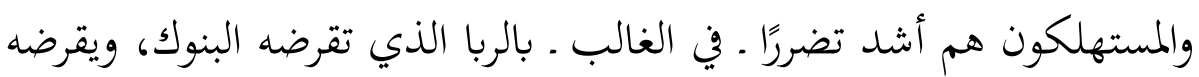

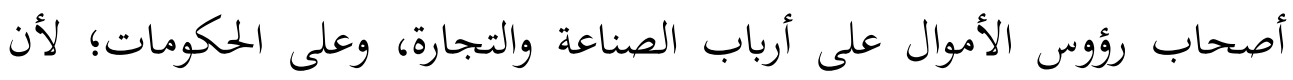

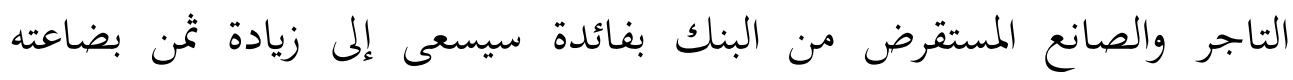

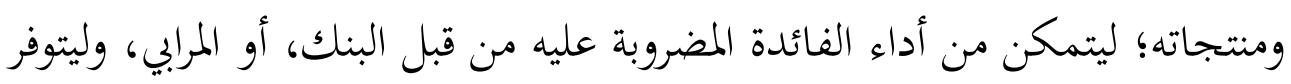

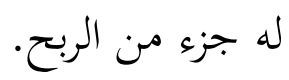

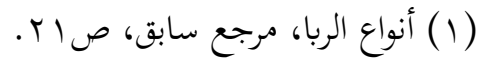

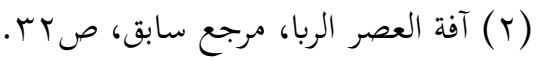


والدولة كذلك إذا اقترضت مالًا من البنك؛ لإقامة مشاريع فسوف تزيد من فرض الضرائب على أفراد المجتمع؛ لتتمكن من أداء الفائدة، فضرر الربا يكون على لإِى كل فرد، سواء تعاملت به الأفراد أو الأمم (1). إذن جميع المستهلكين يؤدون ضريبة غير مباشرة للمرابين، وأصحاب

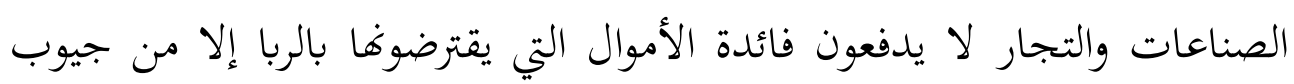

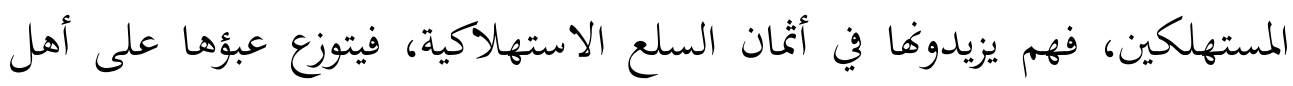
الأرض؛ لتدخل في جيوب المرابين في النهاية، أما الديون التي تقترضها الحكومات من بيوت المال وصناديق النقد؛ لتقوم بالإصالاحات والمشروعات العمرانية؛ فإن رعاياها هم الذين يؤدون فائدها للبيوت الربوية كذلك؛ إذ إن هذه الحكومات تضطر إلى زيادة الضرائب المختلفة؛ لتسدد منها هذه الديون وفوائدها، وبذلك يشترك كل فرد في دفع هذه الجزية للمرابين في فاية المطاف، وقلما ينتهي الأمر

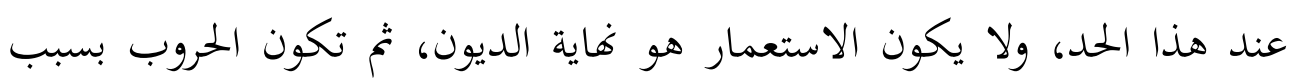
الاستعمار (r) - (ب)

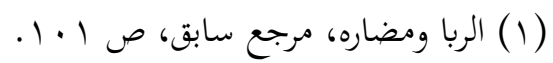

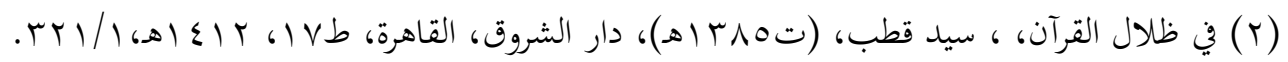




\section{المبحث السادس}

\section{التخلص من الركود والكساد المحليين والعالميين}

عندما ترتفع أثمان الأشياء ارتفاعًا كبيرً فإنان الناس يقل إقبالهم على السلع والخدمات المرتفعة الأثمان، إما لعدم قدرثم على دفع أثماها، وإما لأها ترهق ميزانيتهم، وإذا امتنع الناس عن الشراء كسدت البضائع في المخازن والأسواق، وعندها تقوم المصانع بتقليل إنتاجها خشية الخسائر فتستغني عن جزء كبير من موظفيها؛ لتخفيض نفقاتما، أو قد تستغني عن جميع عمالها وموظفيها، إذا توقف الإنتاج، كما حدث للكثير من شركات السيارات في الولايات المتحدة عام (1)

يقول الدكتور عمر سليمان الأشقر : "إذا ارتفعت أثتان الأشياء ارتفاعًا عاليًا فإن الناس يكفون عن الإقبال على السلع والخدمات المرتفعة الأثمان، إما لعدم إلماء قدرهم على دفع أثماها، أو لأها ترهق ميزانيتهم، وإذا امتنع الناس عن الشراء كسدت البضائع في المخازن والمتاجر، وعند ذلك تقلل المصانع من الإنتاج، وقد

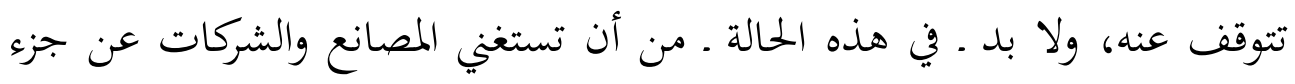
من عمَّالها وموظفيها في حالة تخفيض إنتاجها، أو تستغني عن جميع عمّالها وموظفيها إذا توقفت عن الإنتاج، فعند ذلك تكون الهزات الاقتصادية..."(r). وليس هذا وحده هو كل ما للربا من جريرة، فإن قيام النظام الاقتصادي على الأساس الربوي يجعل العلاقة بين أصحاب الأموال وبين العاملين في التجارة

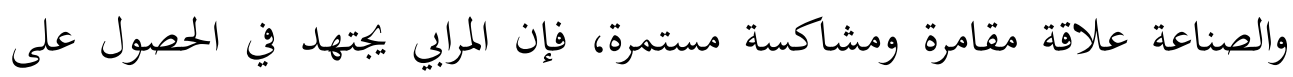
أكبر فائدة، ومن ثم يمسك المال حتى يزيد اضطرار التجارة والصناعة إليه، فيرفع سعر الفائدة، ويظل يرفع السعر حتى يجد العاملون في التجارة والصناعة أنه لا يلا ئل فائدة لهم من استخدام هذا المال؛ لأنه لا يُدر عليهم ما يوفون به الفائدة، ويفضل 
لهم منه شيء، عندئذ ينكمش حجم المال المستخدم في هذه المجالات التي تشتغل فيها الملايين، وتضيق المصانع دائرة إنتاجها، ويتعطل العمال؛ فتقل القدرة على الشراء (1) فالربا بما يحدثه في النفوس من أمراض، وبما يوجده في الاقتصاد من بلايا، وبما

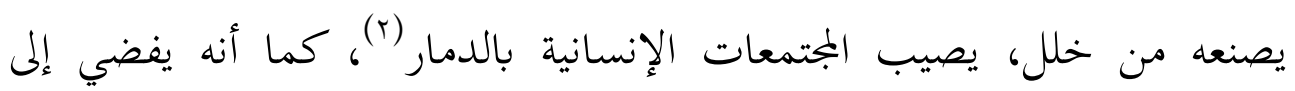

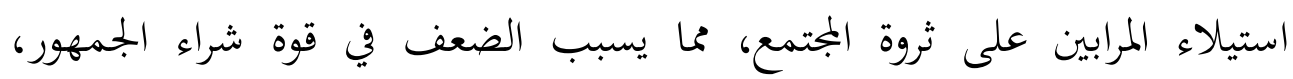
والكساد في صناعة البلاد، وبتحارتا بصفة متصلة، حتى أنه لا يدع أخيرً للأفراد الرأسماليين أنفسهم بجالًا إلى تقليب ثروقم المدخرة في عمل مثمر (r). 


\section{المبحث السابع}

\section{القضاء على ظاهرة الطبقية المالية والجمتمعية وسُوء توزيع الثروة

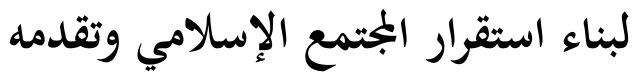

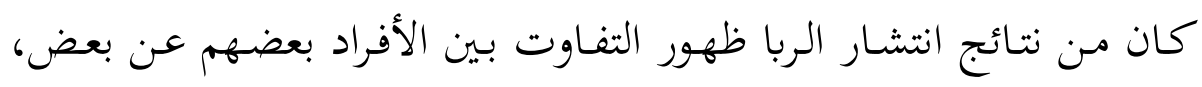

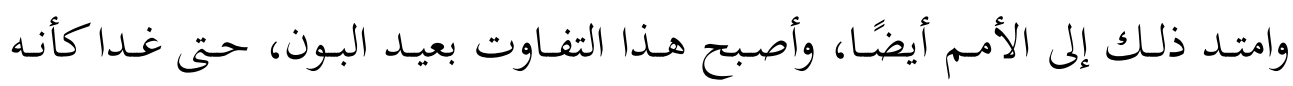

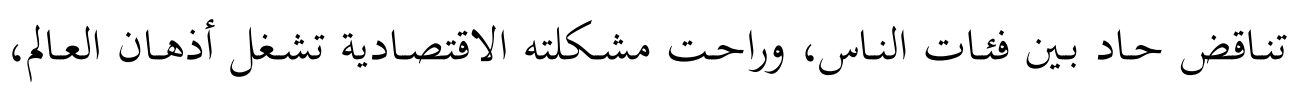

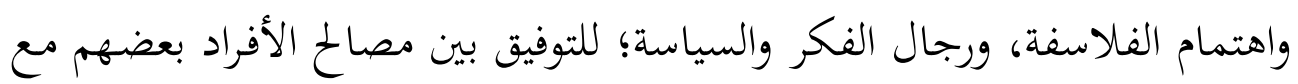
بعض، والتوفيق بين مصالحهم وبين مصلحة المجتمع (1).

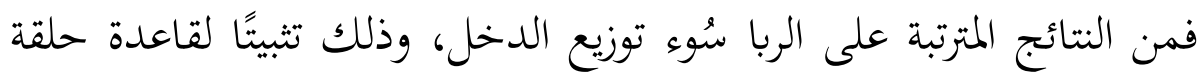

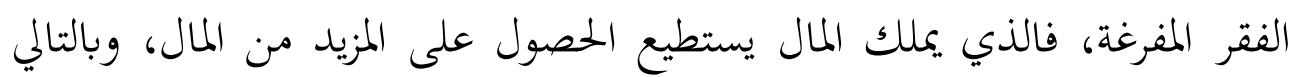

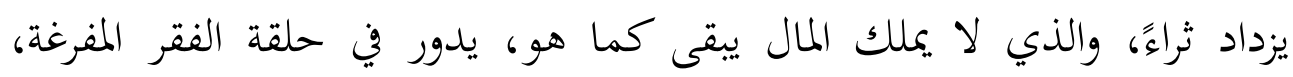
وبالتالي زيادة الهوة بين الفُقراء والأغنياء (r).

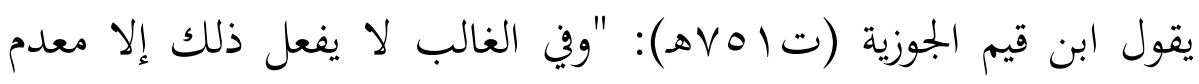

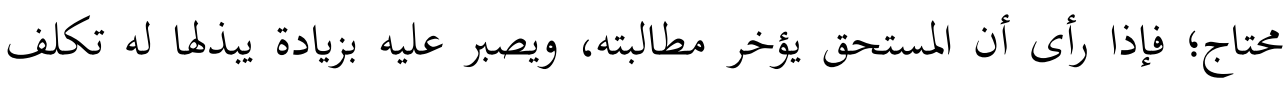

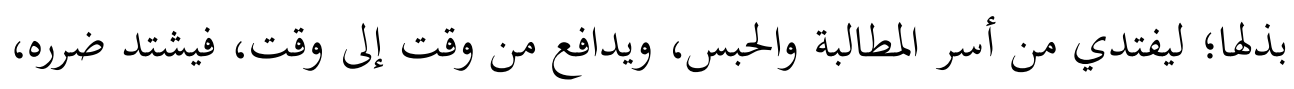

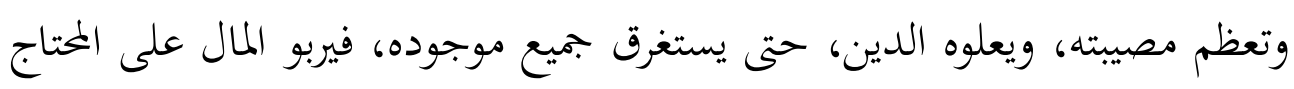

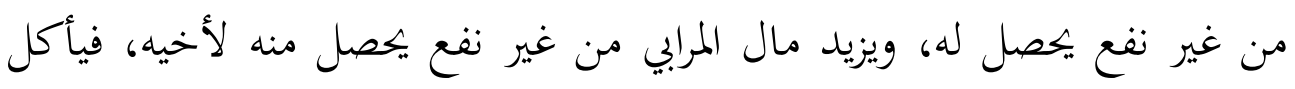
مال أخيه بالباطل، ويكصل أخوه على غاية الضرر" (r).

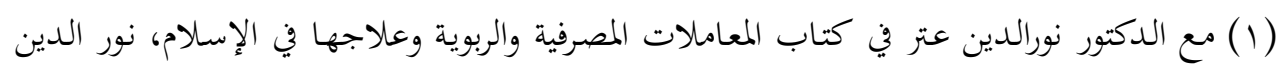

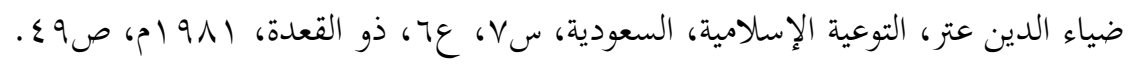

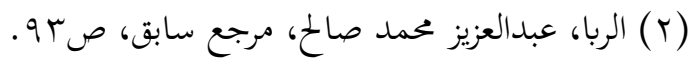

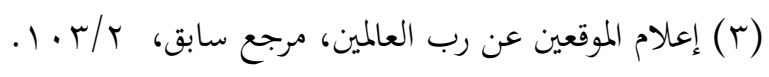


فمن خلال انتشار الربا نجد أنه يقسم المجتمع إلى طبقتين: طبقة تملك المال، وترابي به، ولا تعمل فهي عاطلة عن العمل، وهي طبقة (المرابين)، التي تستغل حاجة الطبقات الأخرى، وأفراد المجتمع، وعامة الشعب، وهي الطبقة الثرية المترفة في المجتمع، القائم على الرأسمالية والربا، وطبقة تعمل ليل غهار، ولا تملك المال، وتبذل كل جهدها، ولا يكفيها قوت يومها، وهي غالبية المجتمع (1).

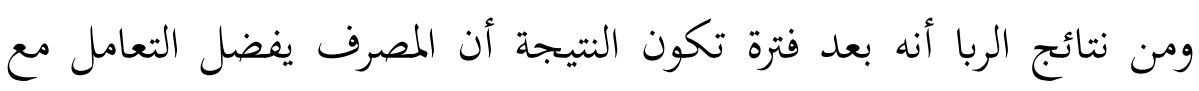
هؤلاء الكبار بالفائدة الثابتة، فيساعد بذلك على دعم الشركات الكبيرة والعملاقة، المتعددة الجنسيات (الاحتكارات الكبرى)، وحرمان المشروعات المتوسطة، والصغيرة؛ ليعود الائتمان المصرفي في خدمة الأغنياء وحدهم (r). وذلك من شأنه ارتفاع الأسعار؛ نتيجة عدم وجود متطلبات الأفراد، فتكثر الواردات، وتتضخم الميزانية العامة، وتتعطل المواهب، ويفتقد الطموح، وتظهر الفوارق الاجتماعية، وتتولد الكراهية، وتنبت الجرائم، وينقطع حبل المودة، ويكون التباغض والتدابر الذي من شأنه قتل الحيوية في جهاز الأمة، مما يعرضها للغزو

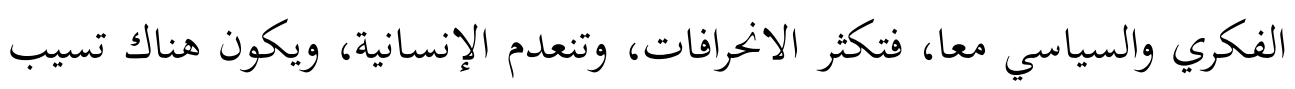
في أموال الدولة، ويفقد الشعور والإحساس بالمسئولية نحو المجتمعات، فتكون التجارة في المخدرات، وفيما هو فاسد في الأطعمة والأشربة(r). وقد ثبت أن الربا أعظم عامل من عوامل تضخم الثروات، وتكدسها في أيدي فئة قليلة من البشر، وأنه سبب البلاء الذي حلّ بالأمم والجماعات؛ حيث لرئ

$$
\text { كثرت المن والفتن، وازدادت الثورات الداخلية(؟). }
$$

(Y) (1) آفة العصر الربا، مرجع سابق، ص.بم.

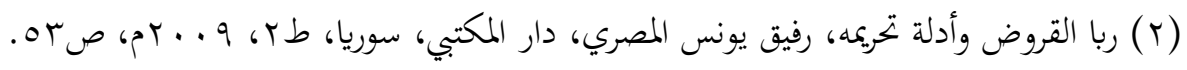

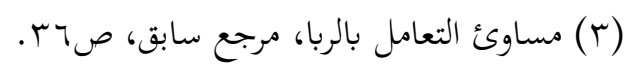

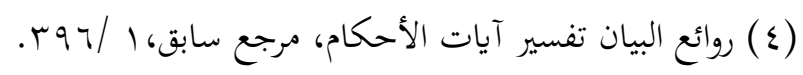


قال الفخر الرازي (ت7 ـ ؟هـ):"فالغالب أن المقرض يكون غنيًا، والمستقرض

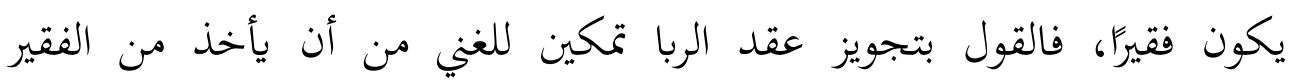

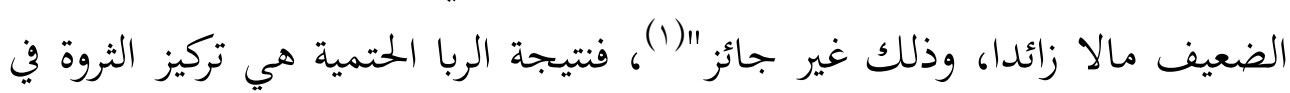

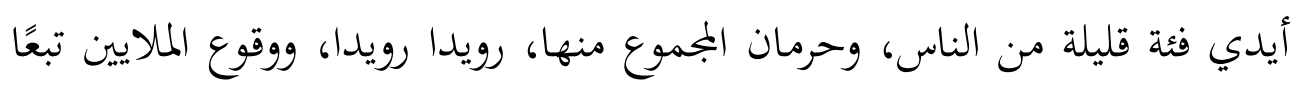

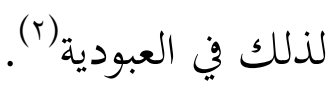
ويقول الدكتور محمد عبدالله دراز: "ذلك أننا بهذه الوسيلة نزيد في توسيع

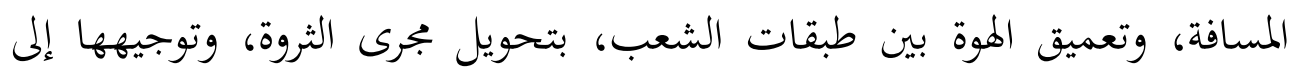

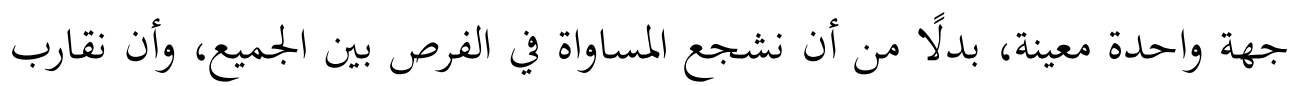
بين مستوى الأمة، حتى يكون أميل إلى التجانس، وأقرب إلى الوحدة" (†).

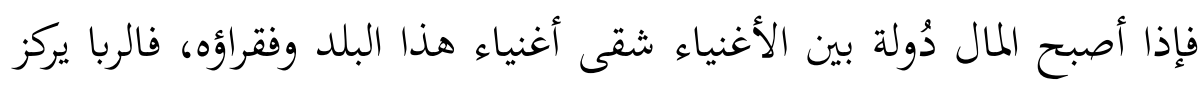

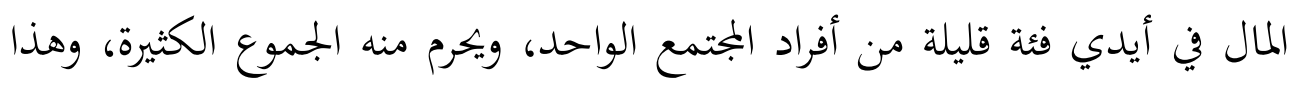

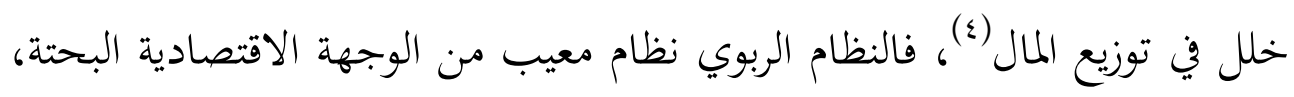

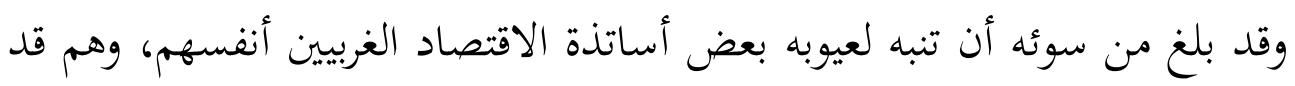

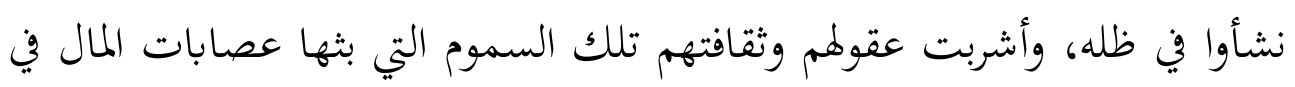

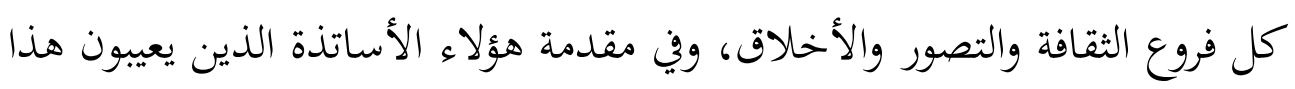
النظام من الناحية الاقتصادية البحتة. يقول (شاخت) مدير بنك الرايخ الألماني Reichs bank سابقًا: "إنه بعملية رياضية (غير متناهية) يتضح أن جميع المال في الأرض صائر إلى عدد قليل جلئ جلدًا

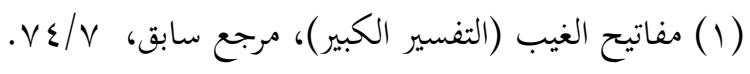

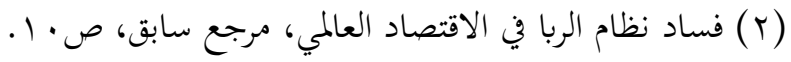

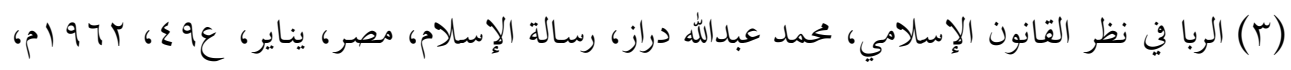

( ) الربا وأثره على المجتمع الإنساني، مرجع سابق، ال/ع ال7. 
من المرابين، ذلك أن الدائن المرابي يربح دائمًا في كل عملية، بينما المدين معرض للربح والحسارة، ومن ثم فإن المال كله في النهاية لا بد بالحساب الرياضي أن يصير إلى الذي يربح دائمًا، وأن هذه النظرية في طريقها لتحقق التكامل، فإن معظم مال

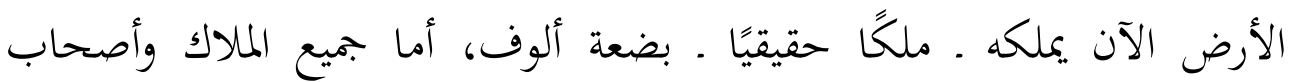
المصانع الذين يستدينون من البنوك والعمال، وغيرهم فهم ليسوا سوى أُجراء يعملون لحساب أصحاب المال، ويجني ثمرة كدهم أولئك الألوف (1). ومن ثم فالجتمع الذي يتعامل بالربا يصبح ججتمعًا مفكگًا، لا يتساعد أفراده فيما بينهم، تعمه الطبقية، فالطبقات الغنية هي المسيطرة، والمتحكمة، وهي قليلة، بينما غالبية المجتمع من الطبقات المعدمة، فتتوسع الفروق الاجتماعية والاقتصادية بين أبناء المجتمع الواحد، وهذا بجتمع لا استتباب لأمنه، مائل إلى التفكك،

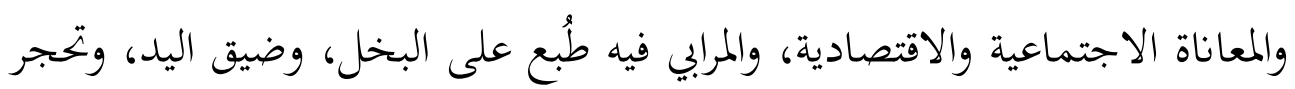
القلب، والعبودية للمال، والتكالب على المادة والدنيا؟(؟). ومن مظاهر سُوء توزيع الثروة تسخير العمل لحساب رأس المال، حيث يقوم

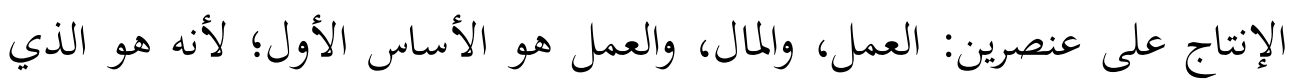
يوجد المال في الأصل، وموجب ذلك أن يتحمل كل من العنصرين نصيبه من الربح والخسارة، فإذا أشركنا صاحب المال في الربح، وجب أن يشترك في الخنارة

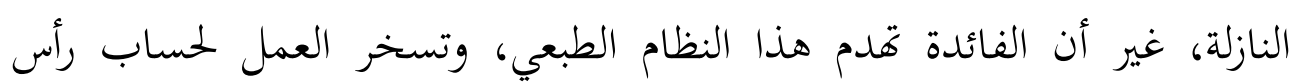

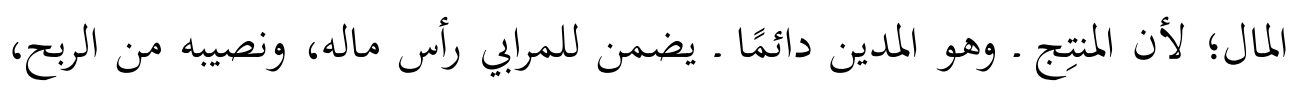
دون أن يشارك هذا الأخير في الخنسارة النازلة(r).

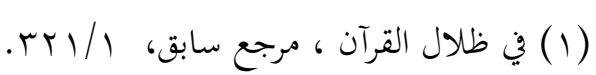

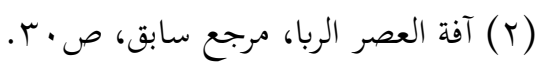

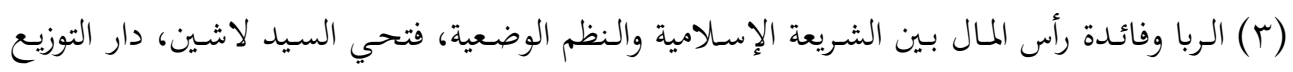

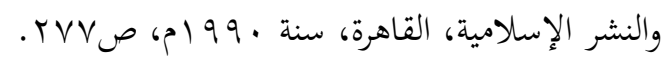


والنتيجة الحتمية من التعامل بالربا مزيد من التباين بين الدخول الدنيا، والدخول العليا لأفراد المجتمع، الأمر الذي يهتم على صانعي السياسات الاقتصادية في عالمنا الإسلامي أن يراجعوا مواقفهم من التعامل بهذا الداء المحرم شرعا، والذي أصبحت آثاره التوزيعية الضارة حقيقة علمية ثابتة، وقابلة للتعميم، تحت مختلف الظروف الاقتصادية السائدة في عالمنا المعاصر (1).

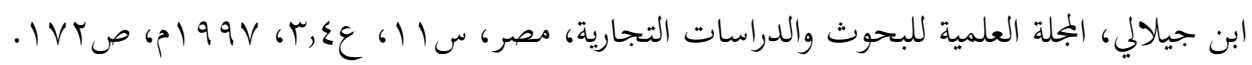


المبحث الثامن

التوجه نحو المشروعات المنتجة والاستثمارية

في ظل اقتصاد حقيقي

الربا يعني أن المال يولّد المال من دون الدخول في الأعمال الإنتاجية، أو الو الاستثمارية، فالمرابي يبحث عن الربح، دونما تعب، أو عمل، بل بإقراض ماله، وانتظار العوائد الربوية، كما تفعل البنوك وملاكها، مما يعني تعطيل جهود فئة كبيرة

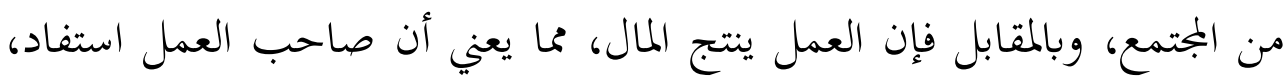

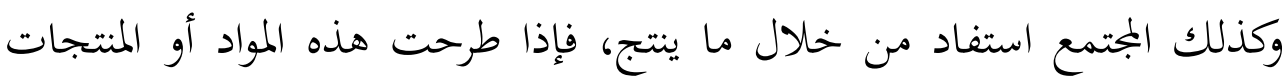

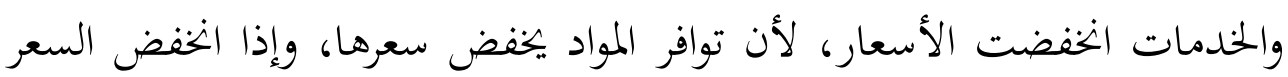
اتسعت شريحة المستفيدين؛ وبالتالي يعم الرخاء، أما إذا ارتفعت الأسعار فالبضائع

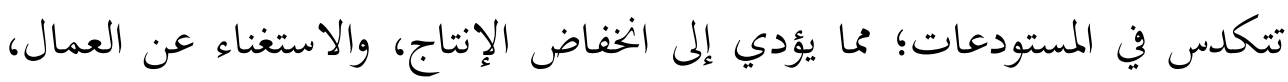
فتزداد البطالة(1) (1)

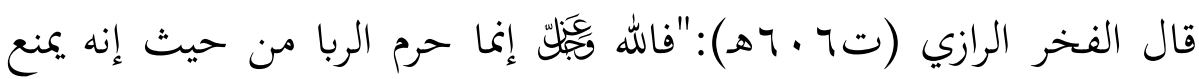
الناس عن الاشتغال بالمكاسب، وذلك لأن صاحب الدرهم إذا تمكن بواسطة عقد الربا من تحصيل الدرهم الزائد نقدًا كان أو نسيئة خف ودن عليه اكتساب ولاب وجها المعيشة، فلا يكاد يتحمل مشقة الكسب، والتجارة، والصناعات الشاقة، وذلك الك الك

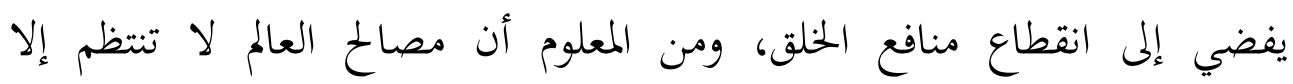
بالتجارات، والحرف، والصناعات، والعمارات" (r).

(1) آفة العصر الربا، مرجع سابق، ص آس.

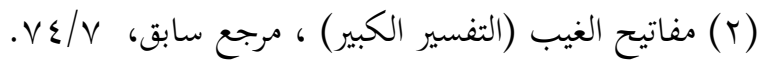
_. 09 _ 
ويقول الشيخ ولي الله الدهلوي (ت7 V ا اهـ): "وَإِذا جرى الرَّنم باستنماء

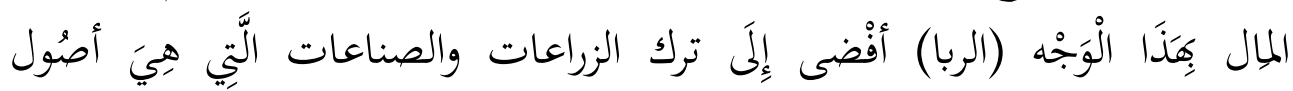
(1)" (1) (لماسب إن روح الربا الذي أشاعه اليهود في العالم، وهي أن يلد المال وحده، دون أن

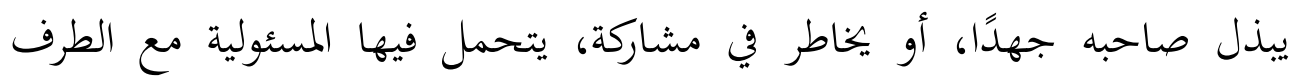
العامل، فيتقاسمان المغرم والمغنم جميعًا، إن كل ما عليه الألف لتعود إليه ألفًا ومائة أو أكثر، بحسب الاتفاق، ولا يهمه ربح الآخر أم خسر، أي: أن ماله ينمو

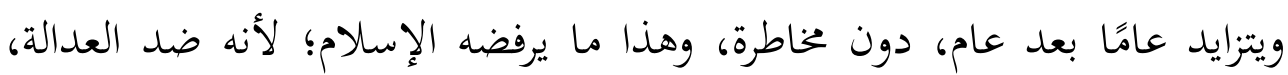
فلأن العدالة الملكمة توجب أن يكون المال والعمل شريكين، متضامنين، متكاملين، لا يعطي أحدهما امتيازًا على الآخر (r). ومن ثم فإن إلغاء الفائدة سيكون دافعًا قويًا للاستثمار، وذلك لكون لكون أسعار الفائدة العالية تعوق الاستثمار؛ لأن تكاليف الفائدة تنزل من الأرباح، محا يؤثر على ربح المشروع المستثمر فيه، لذا فإن خلق مُناخ استثماري إيجابي يتطلب الحفاظ الدائم على العدالة، وعلى التوازن بين المدخرين، والمستثمرين، وإلغاء

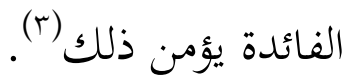
فالأساس الحقيقي للاقتصاد هو العمل، فالمادة الخام في ذاقا لا قيمة لها، ولكن العمل هو الذي يعطيها القيمة، ولذذا فإن العمل يعد سلعة تباع وتشترى، والعامل الفرد ضعيف أمام صاحب رأس المال أو صاحب المصنع (ع).

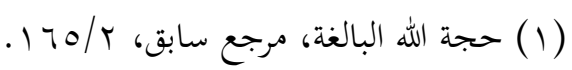

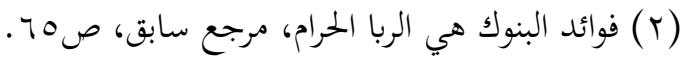

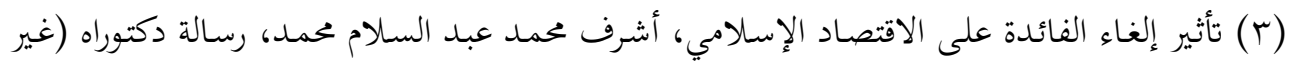

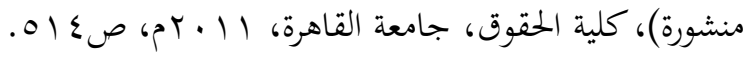

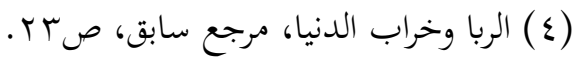


فالمال لا يلد المال بذاته، والنقود لا تلد نقودًا، إنما ينمو المال بالعمل وبذل

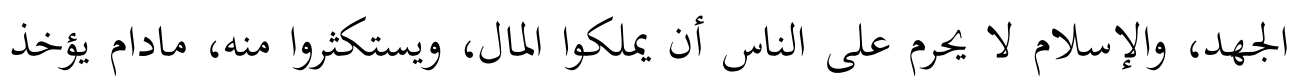

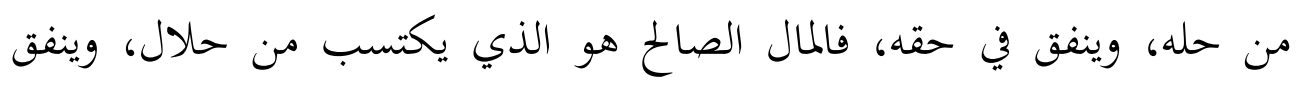

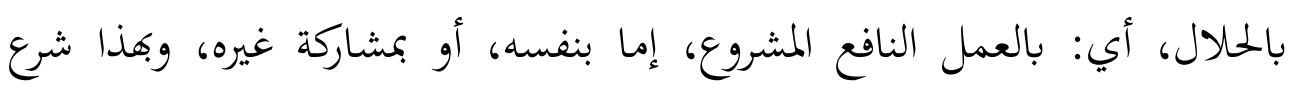

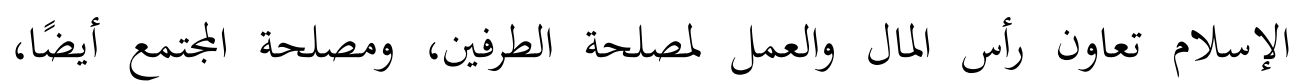

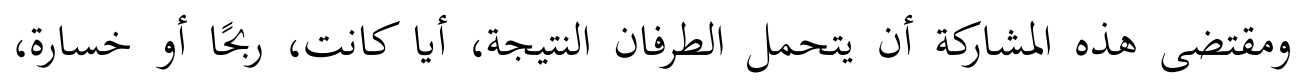

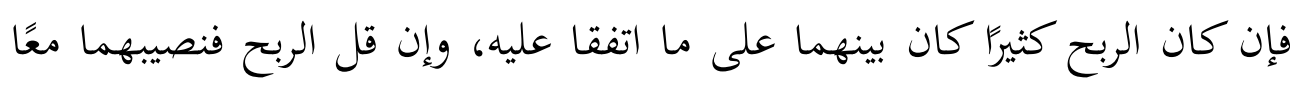

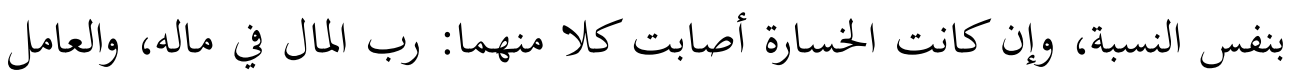
في جهده وتعبه (1). وخلاصة القول فإن لعنة الربا وبلاءاته وشروره تلاحق الشعوب والأمم التي

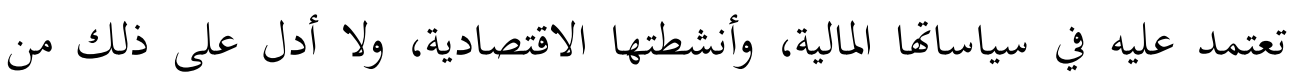

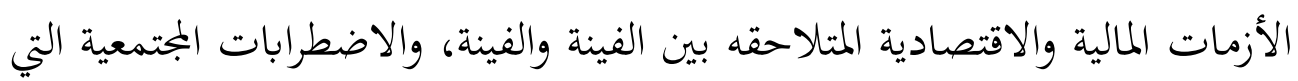

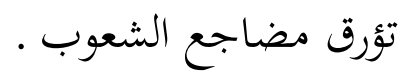




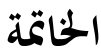

أولًا: النتائج:

هالربا اعتداء مغلف على المال، وأكل لأموال الناس بالباطل، واستغلال لحاجة المحتاج، وكلما اتسعت دائرته عظم خطره، واستشرى ضرره؛ لأنه يتجاوز نطاق الفرد إلى امتصاص أموال الأمة، وتكبيل اقتصادها، والسيطرة على قدراتما ورهات وإمكاناتها.

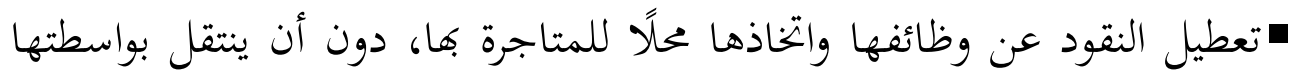

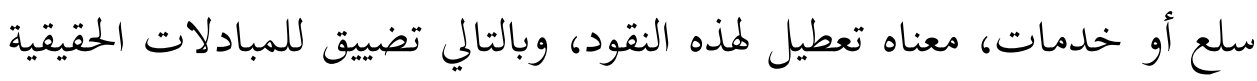
في الجمتمع، وعرقلة للإنتاج، وزيادة البطالة، أما توجيه النقود إلى وظيفتهاه

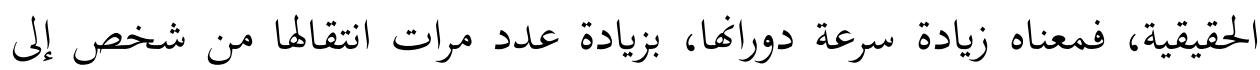
أخر، وبالتالي زيادة حجم المبادلات، وزيادة للتشغيل والعمالة، ومن ثم زيادة دئه لالإنتاج.

مالفائدة على رأس المال تكلفة الانتظار، وليست تكلفة التقليب والمخاطرة، وهي استغلال لجهد الناس، وجزاء من غير بذل جهد، وهذا يخالف قاعدة (الغُنم بالغُرم).

•الربا هو فائض القيمة الذي يأكله القوي دون مبرر، والكسب الخبيث المرم، والسحت الذي لا ضير فيه، ولا بركة منه، بل يجلب الضرر والنقيصة في الدنيا،

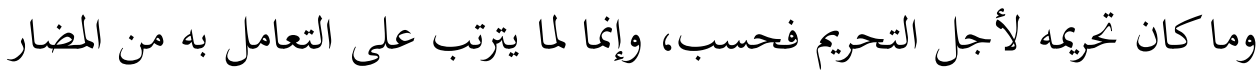

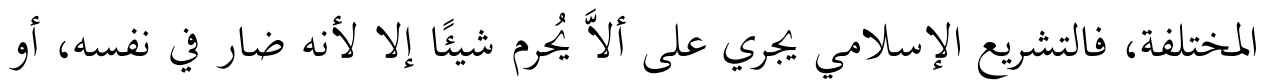
لغلبة ضرره، وللربا مضار تحققت في الواقع العملي. 
التمويل عن طريق الفائدة هو الأب الحقيقي للتضخم، فكلما ارتفعت الفائدة تدهور النقد، فالفائدة العالية تدمر النقود، والفائدة تعد عالية إذا زادت عن معدل الإنتاجية في المجتمع، وكل زيادة في الفوائد عن معدل الزيادة في الإنتاجية معناه حقن التضخم بمزيد من الجرعات المنشطة. • حظر الربا منهج أصيل للتخلص من الركود والكساد، فعندما ترتفع أثمان الأشياء ارتفاعًا كبيرً فإن الناس يقل إقبالهم على السلع والحندمات المرتفعة الأثمان، إما لعدم قدرقم على دفع أثماها، أو لأها ترهق ميزانيتهم، وإذا امتنع الناس عن الشراء كسدت البضائع في المخازن والأسواق، وعندها تقوم المصانع بتقليل إنتاجها لخوف الخسائر، فتستغني عن جزء كبير من موظفيها؛ لتخفيض نفقاها، أو قد تستغني عن جميع عمالها وموظفيها. •الربا يجمع أموال الأمة في يد طبقة معينة، تتحكم في رقاب الناس، واقتصاد البلاد، وهو خلاف مبدأ شمول الثروة كل أفراد المجتمع، وحظر الربا طريق مباشر للتخلص من ظاهرة الطبقية المالية والمجتمعية وسُوء توزيع الثروة؛ لبناء استقرار

$$
\text { المجتمع الإسلامي وتقدمه. }
$$

••إلغاء الفائدة سيكون دافعًا قويًا للاستثمار، وذلك لكون أسعار الفائدة العالية تعوق الاستثمار؛ لأن تكاليف الفائدة تنزل من الأرباح، مما يؤثر على ربح المشروع المستثمر فيه، لذا فإن خلق مُناخ استثماري إيجابي يتطلب الحفاظ الدائم على العدالة، وعلى التوازن بين المدخرين، والمستثمرين، وإلغاء الفائدة يؤمن ذلك.

"يتسبب الربا في انتشار البطالة؛ وذلك لأن أصحاب الأموال يفضلون أموالهم بالربا على استثمارها في إقامة مشروعات صناعية، أو زراعية، أو بتحارية، وهذا 
من نشأنه التقليل من فرص العمل، فتنتشر البطالة في الجمتمعات التي يسود فيها التعامل الربوي.

•للربا تأثير سيء على اقتصاد المجتمع الذي ينتشر فيه، فهو يصرف أصحاب الأموال عن استثمار أموالهم في المشروعات المفيدة للمجتمع، ويوسع دائرة البطالة، ويسبب ارتفاع الأسعار، ويؤثر على قوى العاملين المقترضين؛ حيث يرون أن ما سيكسبونه بعرق جبينهم سيسلبه المرابون الظالمون، فتقل رغبتهم في العمل، ومن ثم يخفض إنتاجهم، وإنتاج المجتمع الذي يعيشون فيه. ثانيا: التوصيات:

"إن لم يبذل المخلصون من الاقتصاديين المسلمين غاية جهدهم المركز والمستمر في توضيح الحكمة الإلمية السامية التي استدعت التهديد بإعلان حرب الله ورسوله على المجتمع الذي يقيم معاملاته على النظام الربوي فستظل قضية الربا قائمة؛ لأن ما يعلنه الفقهاء من علل خلف تحريم الربا ما يزال لا يرتقي بعد إلى حد إلجام المكابرين. •لا بد أن يعمل القائمون على رأس الجهاز المصرفي الإسلامي في كل أنحاء العالم. كُل في مكانه ـ على تطبيق الأعمال المصرفية الخالية من الربا، وأن يزنوها بميزاها الصحيح طبقًا؛ لتعاليم الشريعة الإسلامية السمحة، وليس تطبيقًا صوريًا، يشوبه الربا، وتكتنفه الشبهات؛ لجمع أكبر عدد من المتعاملين الذين لا يحبون التعامل بالربا. •ضرورة تحسين الصورة المغلوطة التي يشيعها البعض عن المؤسسات المالية المتوافقة مع أحكام الشريعة الإسالامية، وتصحيح اعتقاد بعضهم أن المصارف الربوية ضرورة لا بد منها في هذا العصر، ودحض دعوة بعض العلمانيين بأن تحكيم 
الشريعة الإسلامية في المعاملات المصرفية مظهر من مظاهر التأخر والجمود والرجعية.

•الابتعاد عن الفتاوى المشبوهة، والاجتهادات الفردية، والآراء الشاذة الخارجة عن نصوص الإجماع، والتي تبيح الربا، أو تسهله، أو تقسمه لأنواع مباحة، وأخرى غير مباحة؛ لتخدم بذلك أهدافًا سياسية، أو اقتصادية، أو غيرها. لال بد من زيادة الاهتمام بالاقتصاد الحقيقي، والذي يهتم بإنتاج السلع

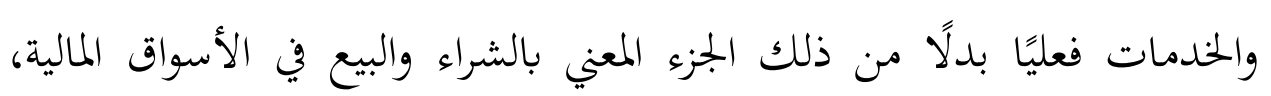
والذي يكون مرتعًا خصبًا للأزمات المالية والاقتصادية الكبرى، والضائقات المالية العالمية، والتقلبات الاقتصادية الجائحة. 


\section{فهرس المصادر والمراجع}

- الآثار الاجتماعيـة والأخلاقيـة والاقتصـادية والتربويـة للمعـاملات الربويـة،

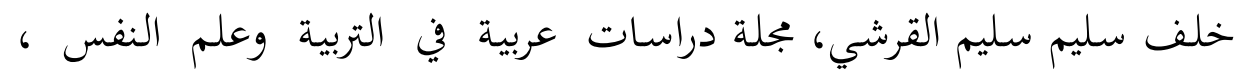

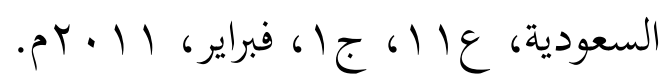

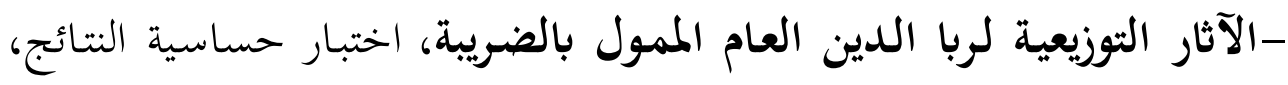

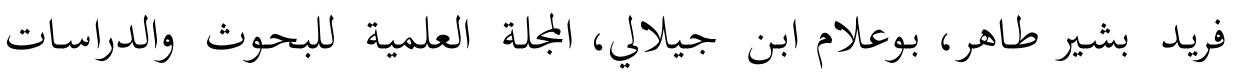

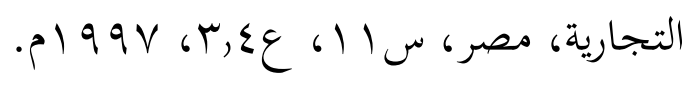
- آثار الربا الاقتصادية، عبدالمجيد عبدالله عبدالمجيد دية، مجلة الشريعة والدراسات

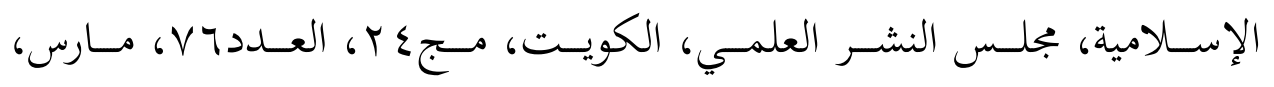

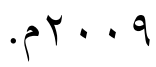

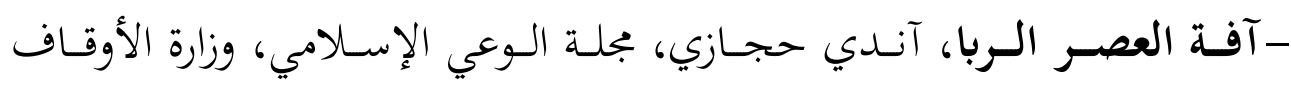

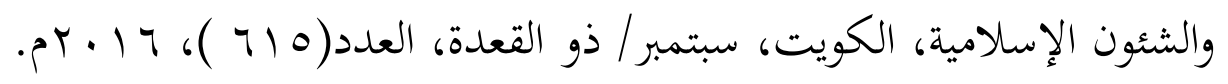

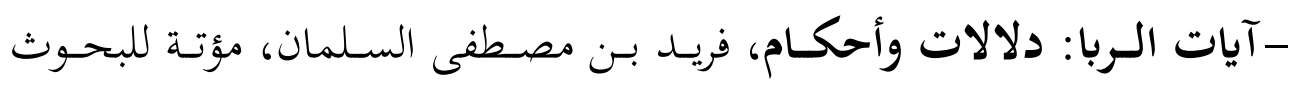

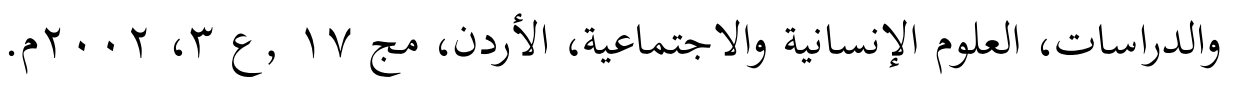

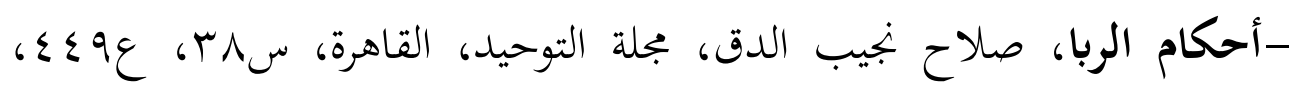
. F . 9 - إحياء علوم الدين، أبو حامد الغزالي (ت ه ـ 0هـ)، طبعة دار الشعب، القاهرة.

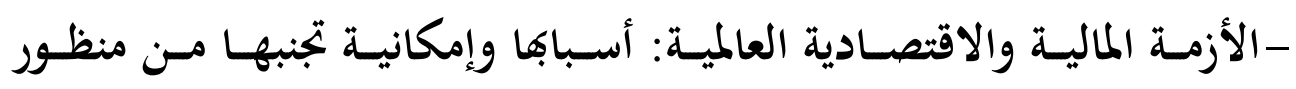

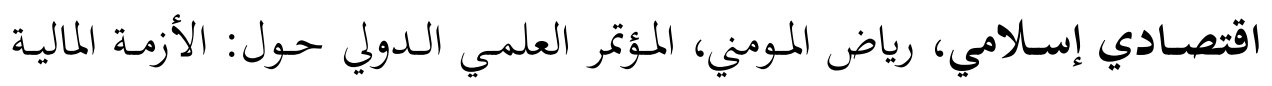

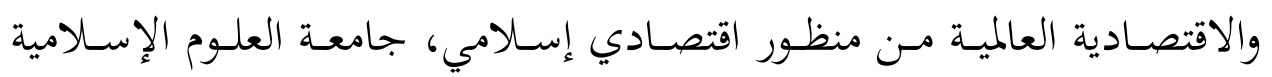

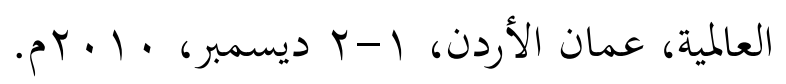

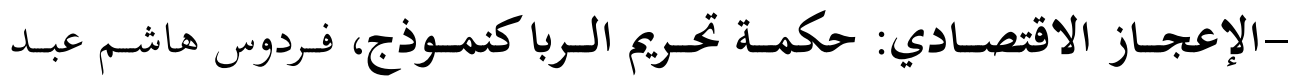

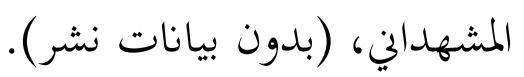


- إعلام الموقعين عن رب العالمين، ابن قيم الجوزية ( ت اه Vه)، تحقيق: طه عبد

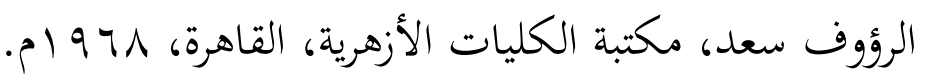

- الاقتصاد الإسلامي بين الفكر والتطبيق، حسين شحاتة، دار النشر

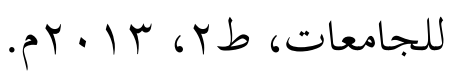

- اقتصـاديات النقود والتوازن النقدي، فؤاد هاشم عوض، دار النهضة العربية،

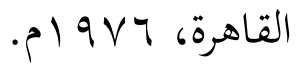

- اقتصــاديات النقــود، عبـــ الـرحمن يسـري أحمـــ، دار الجامعــات المصـرية،

$$
\text { الإسكندرية، } 9 \text { | } 9 \text { ام. }
$$

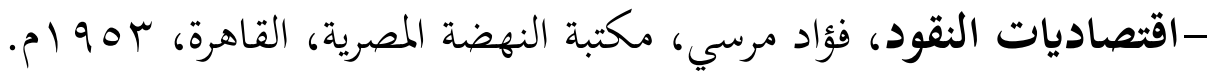
-اقتصاديات ربا الفضل: نحو نموذج تحليلي موحد لأنواع الربا، سامي بن إبراهيم

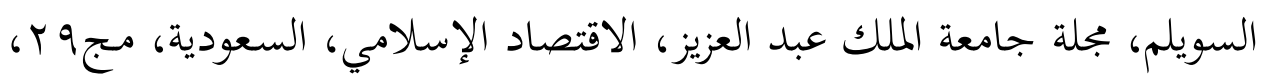

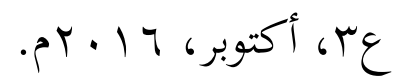

-أنواع الربا: دراسة مقارنة في الفقه الإسلامي، عبد الله بن محمد بن عبد العزيز الشتري، رسـالة ماجستير(غير منشـورة)، المعهـد العـالي للقضـاء، جامعـة الإمـام

$$
\text { محمد بن سعود الإسلامية، السعودية، ع • ع أهـ. }
$$

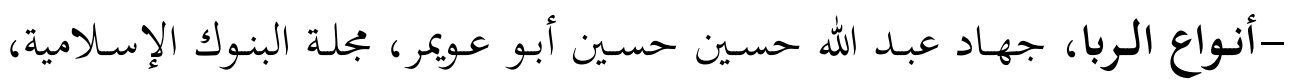

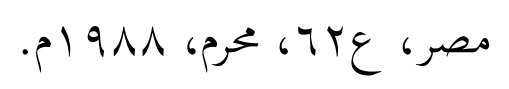

- أنيس الفقهاء في تعريفات الألفاظ المتداولة بين الفقهاء، قاسم بن عبد الله بن علي القونوي(ت V VAه)، تحقيق: يهيى حسن مراد، دار الكتب العلمية،

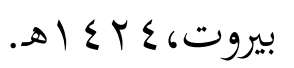

-بحث في الربا: أنواعه وأحكامه، عبدالكريم الخطيب، أضواء الشريعة، السعودية، $. p) 9 \vee \leqslant 60$ 
- البحر الرائق شح كنز الدقائق، زين الدين بن نجيم (ت • و هـ)، ضبطه: زكريا

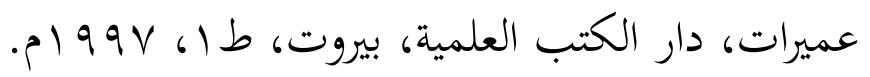

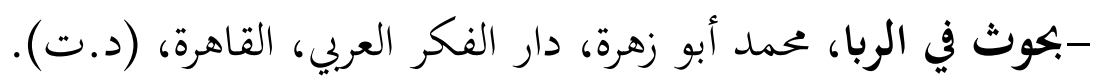

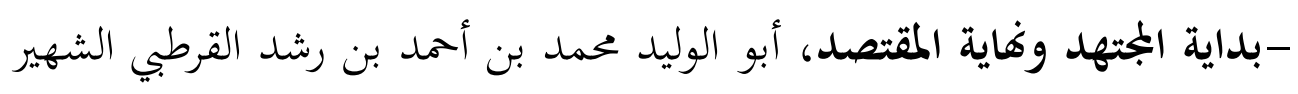

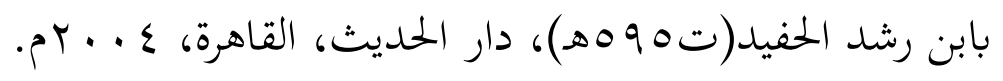

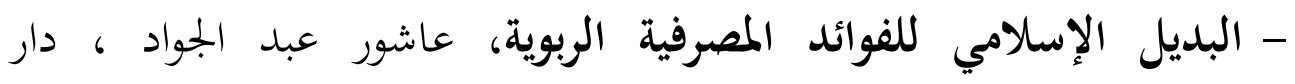

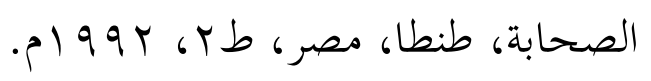

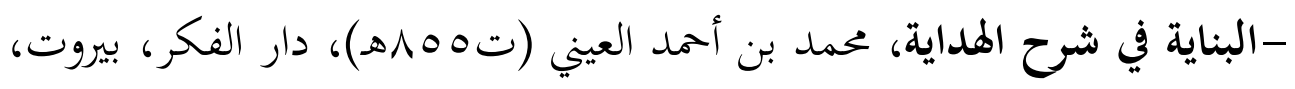

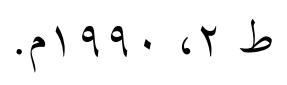
- تأثير إلفاء الفائدة على الاقتصاد الإسلامي، أشرف محمد عبد السلام محمد،

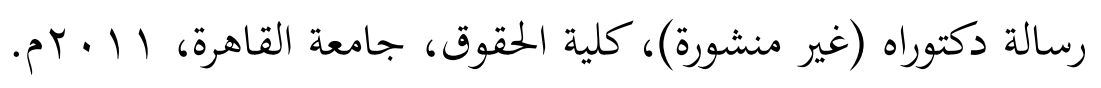

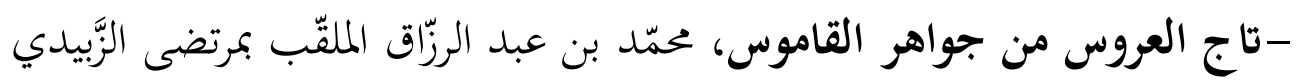

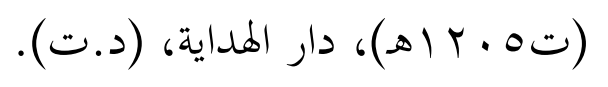

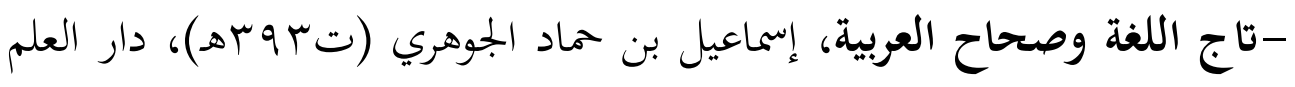

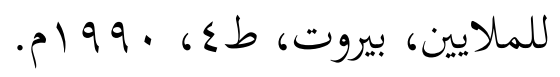

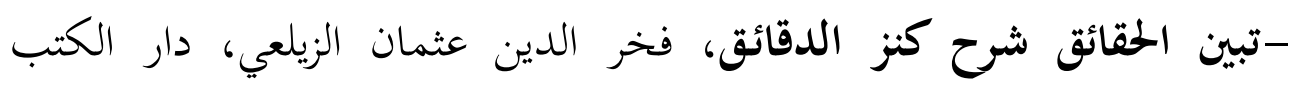

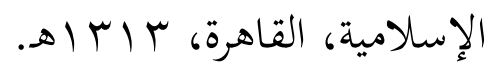

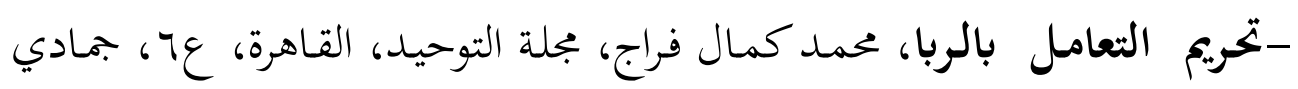

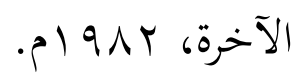

- تحفة الحبيب على شرح الخطيب (حاشية البجيرمي على الخطيب)، سليمان

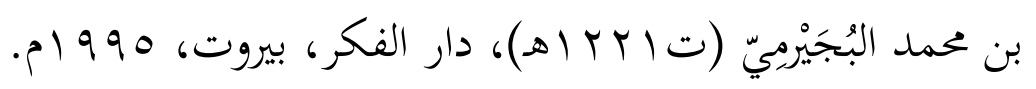


- التدابير الواقية من الربا في الإسالام، فضل إلهي بن شيخ ظهور إلهي، رسالة

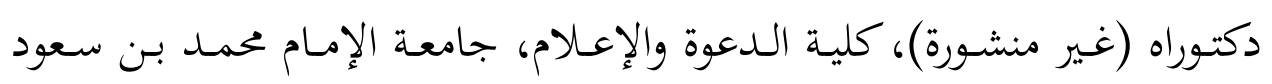

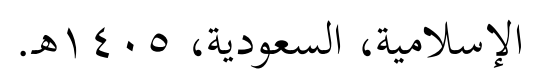

- التضـحم الملالي، غـازي حسـين عناية، مؤسسة شباب الجامعـة، الإسكندرية، . $r$ r....

- التعريفات، علي بن محمد الشريف الجرجاني (ت7 ا مهـ)،دار الكتب العلمية،

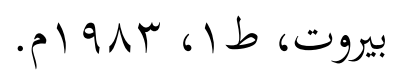

- تفسير الطبري ( جامع البيان عن تأويل آي القرآن)، محمد بن جرير بن يزيد

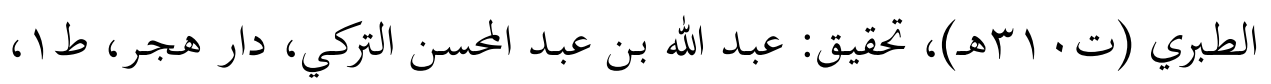
$\cdot p^{2} \cdot 1$

-تفسير القرآن الحكيم (تفسير المنار)، محمد رشيد رضا (تعـه إهـ)، الهيئة المصرية العامة للكتاب، القاهرة، • 99 ام.

-تقويم الربا، محمود عارف وهبة، بجلة المسلم المعاصر، مصر، صفر ـ يناير، .p 9116 rog - التوقيف على مهمات التعاريف، عبد الرؤوف المناوي (ت اسب (اه)، عالم

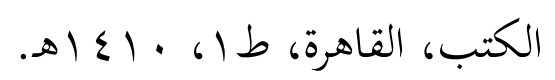

- حجة الله البالغة، أحمد بن عبد الرحيم بن معظم بن منصور المعروف بـ الولي

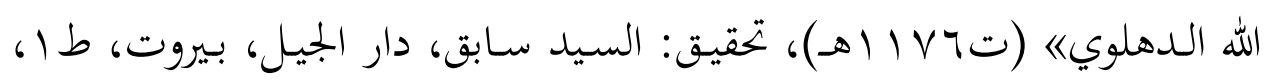
.

- دراسة تاريخية لنشأة الربا، أحمد حسن رضوان، بجلة البنوك الإسلامية، مصر،

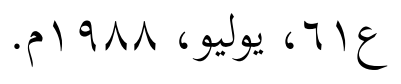


- دسـتور العلمـاء (جـامع العلـوم في اصسطلاحات الفنـون)، عبـد النبي بن عبـد

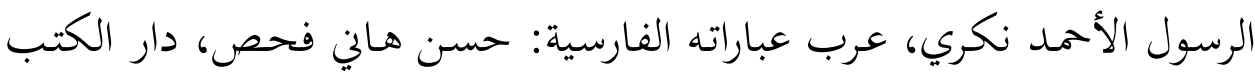

$$
\text { العلمية، بيروت، ط اك . . . م. م. }
$$

- دور النظرة الإسلامية للربا في الوقاية من الأزمات الاقتصادية، إحسان سمارة،

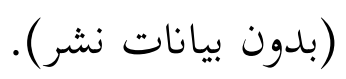

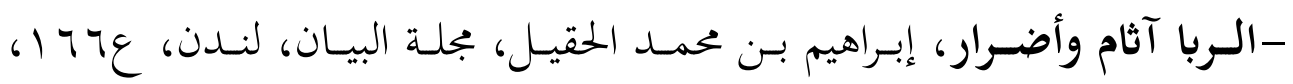

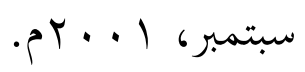

- ربا الجاهلية والفائدة، نوري عبد الرسول الخاقاني، ججلة مركز دراسات الكوفة-

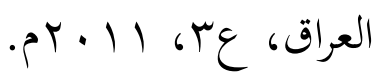

-ربا القـروض وأدلـة تحريمـه، رفيـق يـونس المصـري، دار المكتبي، سـوريا، طبك،

$$
\text { . pr. } 9
$$

-الربا بين الفقهاء والاقتصادين، أحمد النجار، مجلة البنوك الاسلامية، مصر،

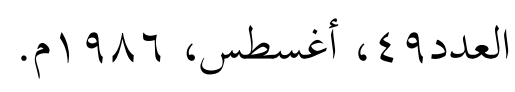

- الـربا حسـدوده وموقـف الاسـلام منسه، أحمـــ جـاب الله شـلبي، مجلـة البنـوك

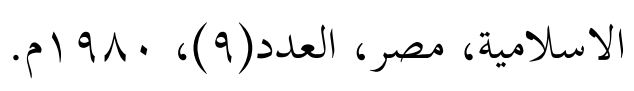

-الـربا في الاسـلام، الاتحـاد الـدولي للبنـوك الإسـلامية، مجلـة البنـوك الإسـلامية،

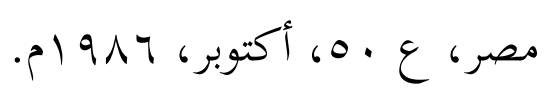

-الربا في نظر القانون الإسلامي، محمد عبدالله دراز، رسالة الإسلام، مصر،

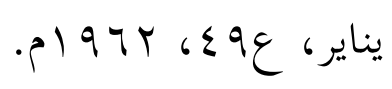

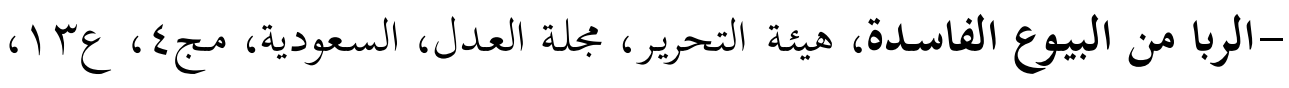

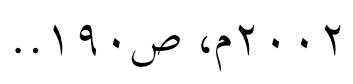

- الربا وآثاره الاجتماعيـة والسياسية والاقتصـادية في مختلف الديانات المؤمنـة والكافرة، فاضل عياث الحمود، ججلة دراسات يمنية، العدد . م. 
-الربا وأثره على الجمتمع الإنساتي، عمر سليمان الأشقر، ضمن كتاب: بحوث فقهية في قضايا اقتصادية معاصرة، دار النفائس، الأردن، ط (1، 999 \م.

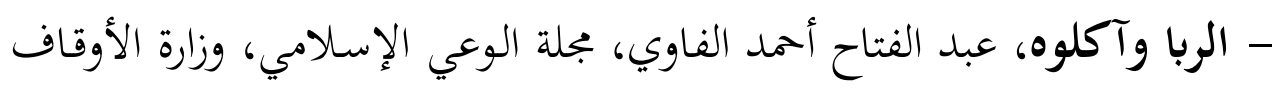

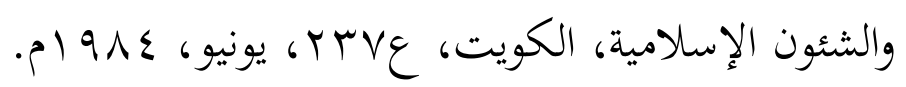

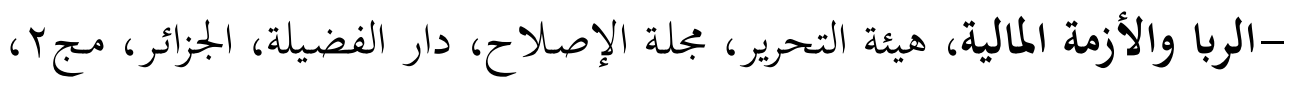

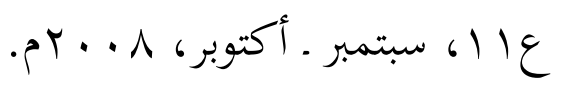

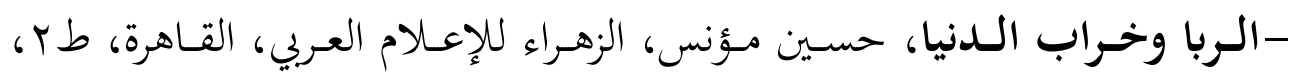

$$
\text { . v० ص ср1917 }
$$

- الربا وفائدة رأس المال بين الثريعة الإسلامية والنظم الوضعية، فتحي السيد لاشين، دار التوزيع والنشر الإسلامية، القاهرة، سنة .99 إم. 99 -الربا ومضـاره، عبدالعزيز بن علي بن عزيز الغامـدي، ججلة كلية الشريعة واللغة

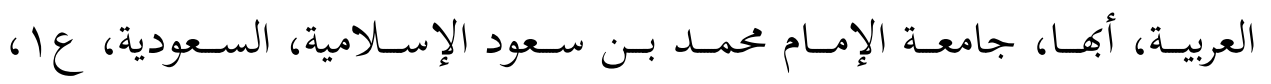
. $) 9 \vee \wedge$ - الـربا: أضسراره وآثاره في ضسوء الكتـاب والسـنة، سعيد بـن علي بـن وهـف القحطاني، تقديم: صالح الفوزان، مؤسسة الجريسي، الرياض.

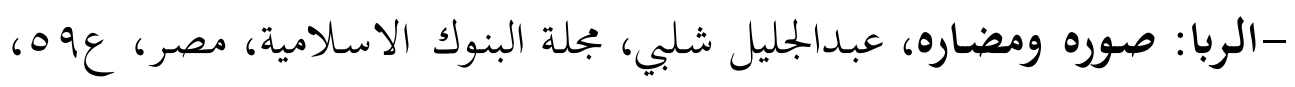

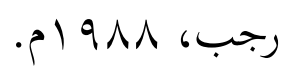

-الـربا، حسـن جعفــ الحفيـان، بجلـة المـال والاقتصـاد، بنـك فيصـل الإسـلامي

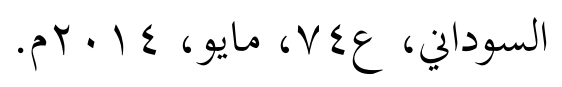

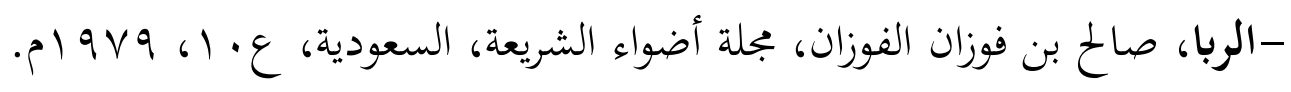

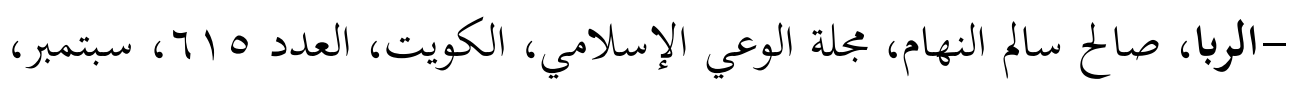
. $r$ r. 17 


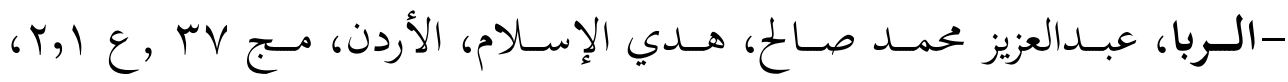
.$<199 r$

-الربا، محمود مفتاح، مجلة كلية الشريعة والقانون بأسيوط، جامعة الأزهر، مصر،

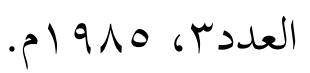

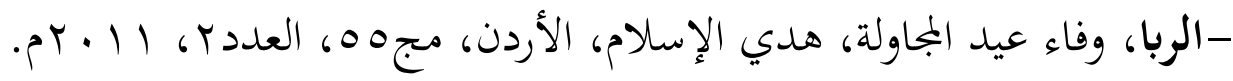

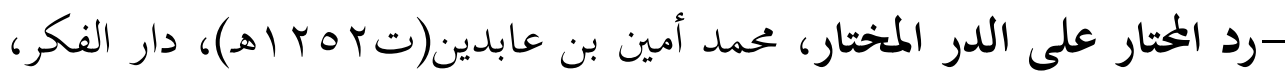

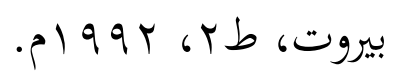

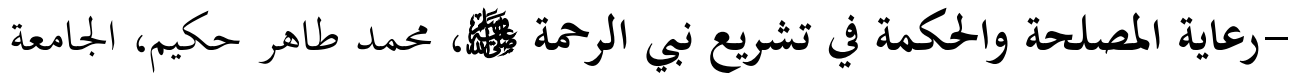

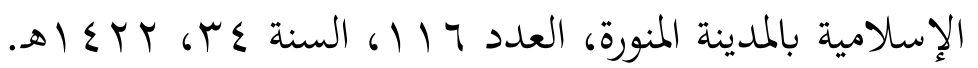

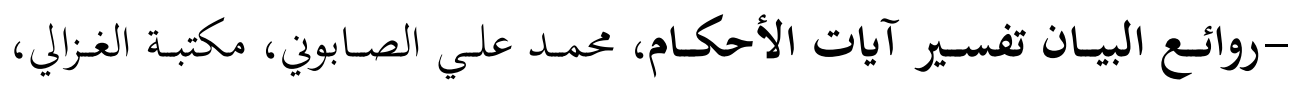

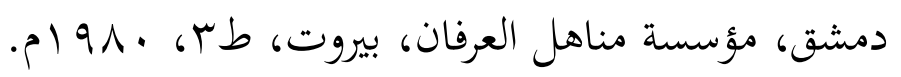

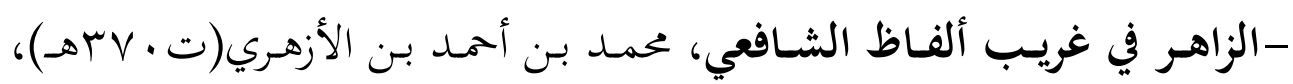
تحقيق: مسعد عبد الحميد السعدني، دار الطلائع.

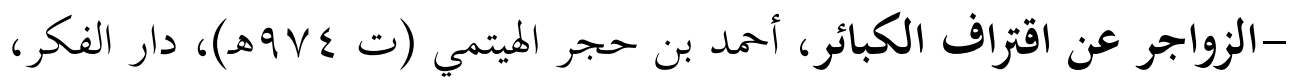

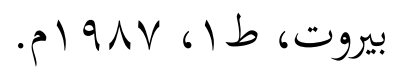

- سياسة معدل الفائدة الصغرى ومبدأ إلغاء الربا في الاقتصاد الإسلامي، أحمد مهدي بلوافي، عبدالرزاق سعيد بلعباس، دراسات اقتصاديه إسلامية، السعودية،

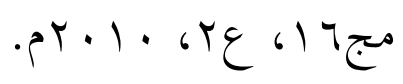

-شرح القواعد الفقهية، أحمد محمد الزرقا، تحقيق: مصطفى أحمد الزرقا، دار

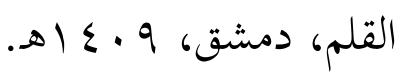

- الثرح الكبير على متن المقنع، عبد الرحمن بن محمد بن أحمد بن قدامة

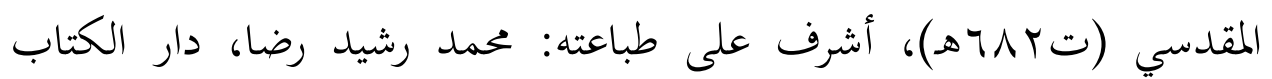

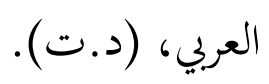


-علاقة البطالة بالجريمة والانحراف في الوطن العربي، أحمد حويتي وآخرون،

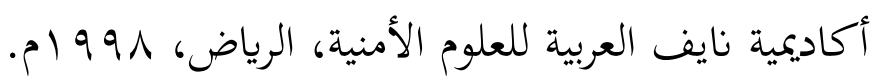

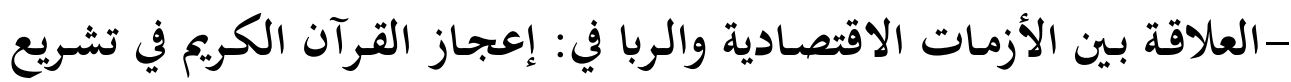
تحريم الربا وتوظيفه في مجالات العلوم الإنسانية والاجتماعية، رفعت السيد

$$
\text { العوضي، (بدون بيانات نشر). }
$$

-العلة الاقتصادية لتحريم ربا النسيئة والفضل، عبد الرحيم عبد الحميد

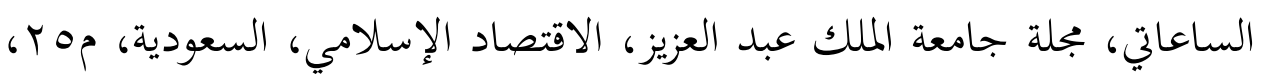

$$
\text { .PT P IT 6 T }
$$

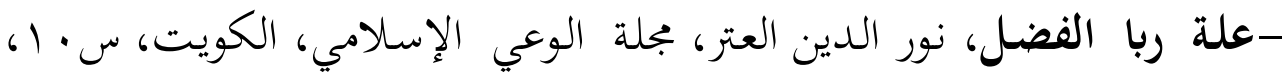

$$
.<19 \vee \leqslant 6117 \varepsilon
$$

- الفـرق بيـع البيـع والـربا في الثـريعة الإسـلامية، بجلـة البحـوث الإسـلامية،

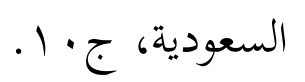

-فسـاد نظام الربا في الاقتصـاد العـالمي، أنور الجندي، دار الأنصـار، القـاهرة،

$$
\text { . (د.) (د) }
$$

- الفِقــه الإسـلامي وأدلتـه، وهبـهـ بـن مصـطفى الزحيلـي، دار الفكـر، سـوريَّة،

$$
\text { (د.د) }
$$

- فوائد البنوك هي الربا الحرام، يوسف القرضاوي، دار الصحوة، القاهرة، طس، . $) 99 \varepsilon$

-في ظعلال القـرآن، سـيد قطب إبراهيم الشـاربي (ت (تمب اهـ)، دار الشـروق،

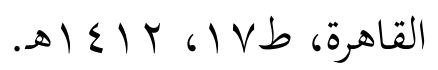

-القاموس الفقهي لغة واصطلاحًا، سعدي أبو حبيب، دار الفكر، سورية، طب،

$$
\text { . } 19 \wedge \Lambda
$$


- كارثة الفائدة، فرايهرفون بيتمان، ترجمة: أحمد النجار، دار الغد العربي، القاهرة، . (د.) (2) - كتاب العين، الخليل بن أحمد الفراهيدي، دار الهلال، (د.ت).

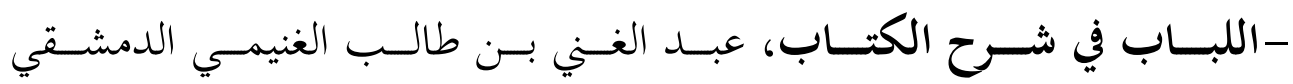

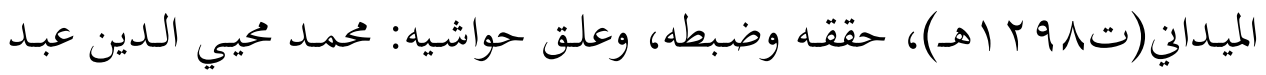
الحميد، المكتبة العلمية، بيروت، (د.ت).

- لسان العرب، محمد بن مكرم بن منظور الأفريقي المصري، دار

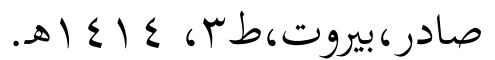
-لعبـة النقود الدولية، روبرت ألبير، ترجمة: عمـاد عبد الرؤوف، مكتبـة مـدبولي،

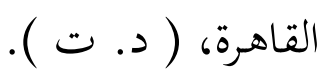

-ملاذا حرم الله الربا، ججد الدين عزام، بجلة البنوك الاسلامية، مصر، العددوهـ،

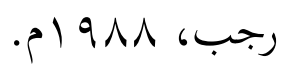

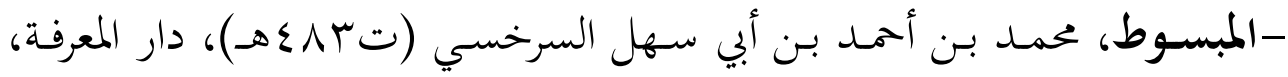

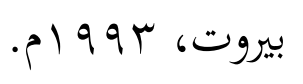

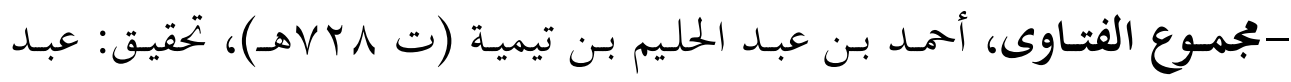

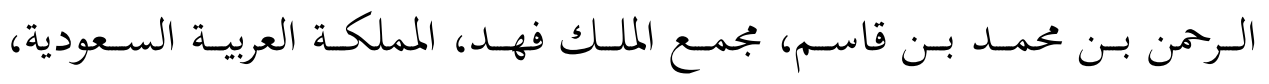
. 1990

- الجمموع، أبو زكريا محيي الدين بن شرف النوري (ت7VT هـ)، دار الفكر، بيروت، $99 \mathrm{~V}$

-مختار الصحاح، أبو بكر الرازي، تحقيق: محمود خاطر، مكتبة لبنان

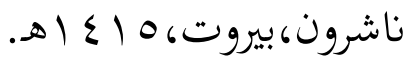
- المـدخل لدراسـة الثــريعة الإسـالامية، يوسـف القرضـاوي، مؤسسـة الرسـالة،

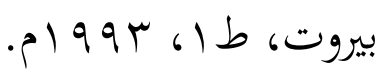


- مساوئ التعامل بالربا، محفوظ إبراهيم فرج، بجلة البنوك الإسالامية، مصر،

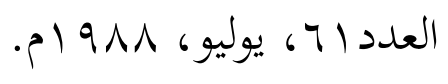

- المصباح المنير، أحمد بن محمد بن علي الفيومي، المكتبة العلمية، بيروت. - مع الدكتور نور الدين عتر في كتاب المعاملات المصرفية واللبوية وعلاجها

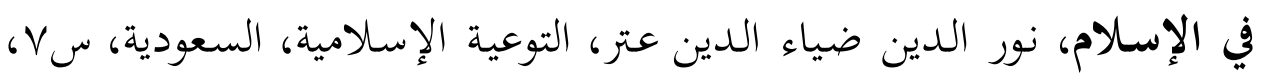

$$
\text { ع }
$$

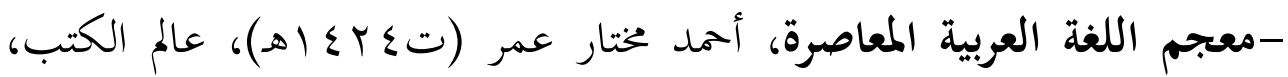

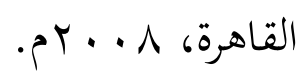

-معجـم لفـة الفقهاء، محمـد رواس قلعجي، حامــ صـادق قنيبي، دار النفـائس،

$$
\text { . } 9 \wedge \wedge 6 r \text { b }
$$

-معجم مصطلحات الاقتصاد والمال (إنجليزي ـ عربي )، نبيه غطاس، مكتبة

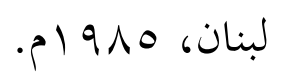

- المغني، عبد الله بن أحمد بن قدامة المقدسي (ت . ب7هـ)، مكتبة القاهرة،

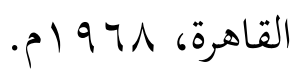

-مفاتيح الغيب (التفسير الكبير)، فخر الدين الرازي (ت7 • بهـ)، دار إحياء

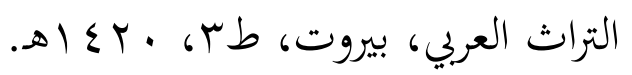

- المفردات في غريب القرآن، أبو القاسم الحسين بن محمد المعروف بالراغب

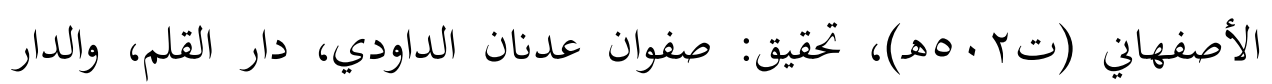

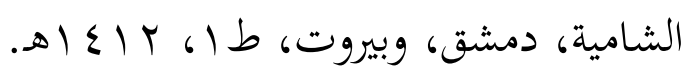

-مـن آثار الربا في التنميـة البشـرية، صـلاح نعمـان العـاني، وأسـامة عبـد المجيد

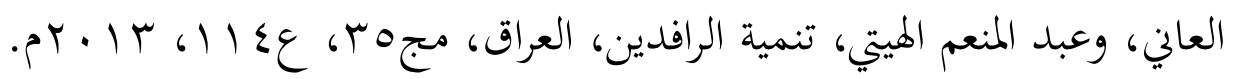

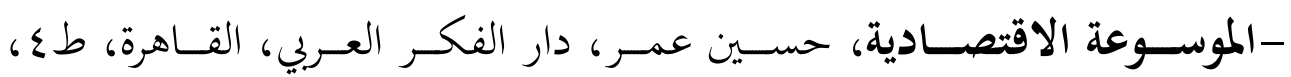


- الموسوعة الاقتصادية، راشد البراوي، دار النهضة العربية، القاهرة، ط) $\cdot \rho|9 V|$

-موقف الإسلام من الربا، محمد عبد الله هاشم، التوعية الإسلامية، السعودية، $\cdot p 191 \cdot 61 \varepsilon$

- النظام الاقتصادي في الإسالام، تقي الدين النبهاني، دار الأمة، بيروت، طج، $\cdot{ }^{2}+\cdot \varepsilon$

- نظرات اقتصـادية في حكمـة تحريم الربا الحففي، كمـال حطاب، مجلة العلوم الاجتماعية والإنسانية، 999 أم.

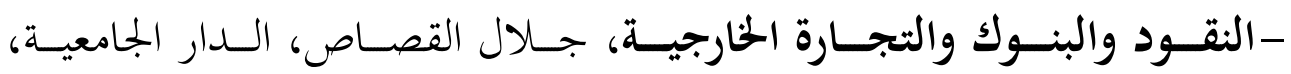

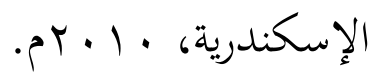

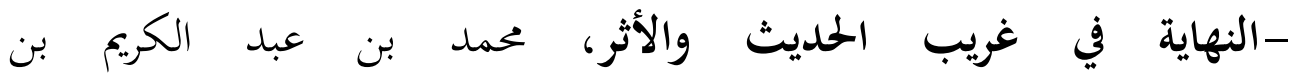
الأثير(ت7 • 7هـ)،تحقيق: طاهر أحمد الزاوي، ومحمود محمد الطناحي، المكتبة

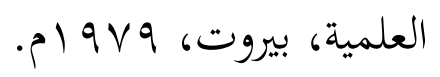
-وضع الربا في البناء الاقتصادي، عيسى عبده، دار الاعتصام، القاهرة، طب، . $) 9 V V$

\section{触触}

